


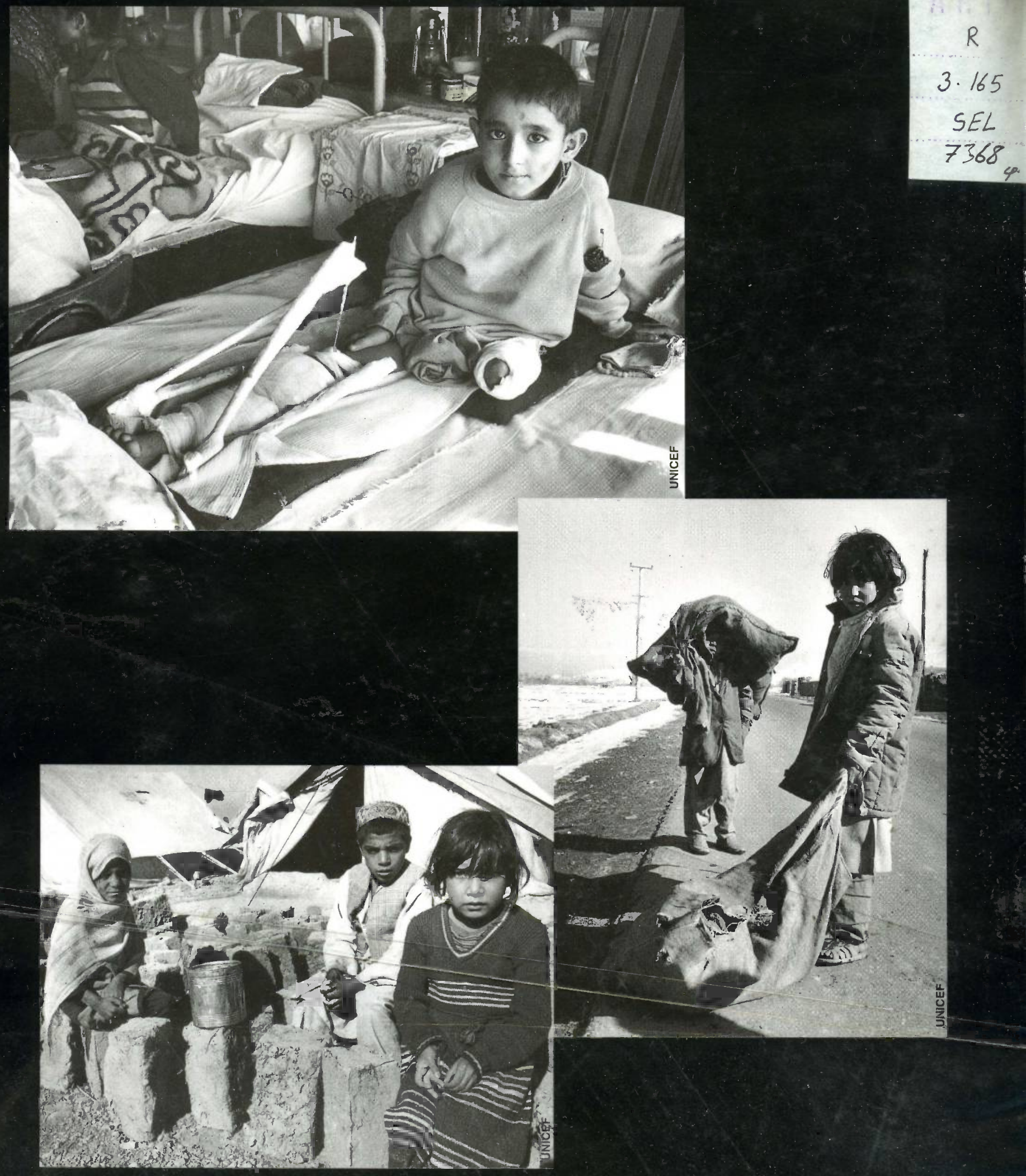

\section{Rädda Barnen}

Save the Children Federation, Inc.

Save the Children (UK)

UNICEF 


\title{
THE IMPACT OF CONFLICT
}

\author{
ON
}

\section{CHILDREN IN AFGHANISTAN}

May 1998

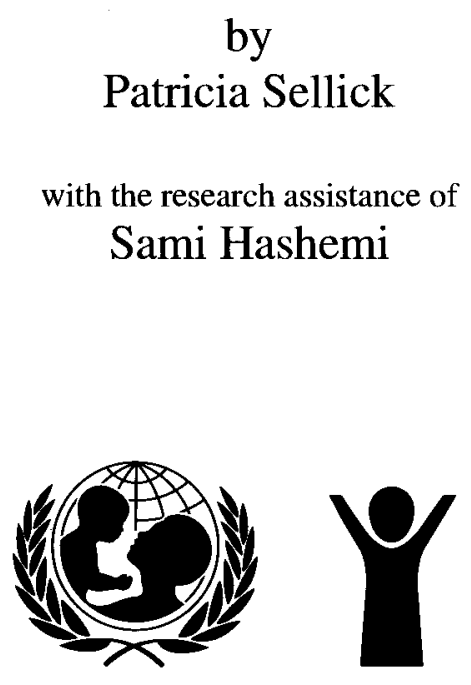

Conducted for:

Rädda Barnen

Save the Children Federation, Inc.

Save the Children (UK)

UNICEF 


\section{CONTENTS}

Report Summary

Acknowledgements

Map

1. Introduction

2. Methodology

3. Survival 16

War fatalities $\quad 16$

Hazardous environments $\quad 17$

Security and shelter $\quad 17$

Financial capacity of parents $\quad 19$

Working children $\quad 21$

Economic necessity and participation in military units $\quad \mathbf{2 3}$

Making a reality of children's rights to survival $\quad 24$

4. Protection 26

Children and gender discrimination $\quad \mathbf{2 6}$

Children and institutions $\quad 29$

Children and disability $\quad 31$

Children and ethnic difference $\quad 32$

Protection from harassment and the forced participation $\quad \mathbf{3 4}$

in military units

Making a reality of children's rights to protection $\quad 35$

5. Development 37

The home $\quad 37$

The mosque and school $\quad \mathbf{4 0}$

Apprenticeships $\quad \mathbf{4 3}$

Volunteering and participation in military units $\quad \mathbf{4 4}$

Making a reality of children's rights to development $\quad 45$ 
6. Participation 47

Children and information $\quad 47$

Children and the media $\quad 48$

Identification with Afghanistan and perceptions of the war $\quad \mathbf{4 8}$

Children as future parents $\quad 49$

Making a reality of children's rights to participation $\quad \mathbf{5 0}$

7. Conclusions and Recommendations 51

Endnotes $\quad 55$

Appendices

I Terms of Reference

II Interview Schedule (Dari; Pashtu)

III Analysis of results

IV Case studies

Additional copies of the report can be requested from:

Rädda Barnen

Room 228, 2nd Floor

Gul Haji Plaza

Jamrud Road

Peshawar N.W.F.P.

Pakistan

Ph: 92-91-840987

Fax: 92-91-840349
Save the Children Federation, Inc.

P.O. Box 1952

14-A, Street 61

F-7/4, Islamabad

Pakistan

Ph: 92-51-279212

Fax: 92-51-279210
Save the Children (UK), Pakistan

194-A, College Road

F-7/3, Islamabad

Pakistan

$\mathrm{Ph}$ : 92-51-279214/5

Fax: 92-51-279216

e-mail: scfuk@infolink.net.pk
United Nations Children's Fund (UNICEF)

Afghanistan Country Office

17-B Abdara Road

P.O. Box 1078

University Town

Peshawar N.W.F.P.

Pakistan

Ph: 92-91-43669

Fax: 92-91-840437
Save the Children (UK) Head Office

17 Grove Lane

London SE5 8RD

$\mathrm{Ph}: \quad 44-171-703-5400$

Fax: 44-171-793-7610

1.illingworth@scfuk.org.uk

The consultant would welcome correspondence related to the report at the following E-mail address: p.sellick@bradford.ac.uk

Edited by: Amanda Sandeman

Designed by: Jennifer Duncan

Printed by: The Army Press 


\section{REPORT SUMMARY}

\section{Introduction}

International concern to improve the care and protection of children in times of war led to the appointment in 1994 of Graça Machel as Expert to the United Nations Secretary General on the Impact of Armed Conflict on Children and the presentation of her report on the subject in 1996. The same concern has prompted regular meetings between four child-focused agencies working in Afghanistan - Rädda Barnen (Save the Children Sweden), Save the Children Federation, Inc., Save the Children (UK) and the United Nations Children's Fund (UNICEF). In order to inform their activities, the group commissioned this research into the situation of children in war-torn Afghanistan.

The development of children in Afghanistan cannot be put on hold until the fighting comes to an end. The need for action is urgent. The research team set out to uncover not only the negative consequences of armed conflict on children, but also the positive resources that children draw on to deal with these consequences and other factors that promote their wellbeing. They assessed which children are especially vulnerable and selected examples of good practice in the field of programming for children. Recognising that longer-term, in-depth research is also required, the team identified further areas for investigation.

The report is organised around the four constituent themes of the UN Convention on the Rights of the Child:

- survival

- protection

- development

- participation.

Making a reality of the rights enshrined in the Convention is part of the mandate of the four childfocused agencies. But in Afghanistan, where the citizens have no recourse to their own state representatives, there are huge barriers to promoting a rights-based approach. However complex the difficulties, the four agencies are committed to finding creative ways of helping the children of Afghanistan break out of the cycle of armed conflict and to assert their undeniable stake in a peaceful future.

\section{Methodology}

Semi-structured interviews with nearly 500 children aged 6-18 were the prime source of information for the research. These were supplemented by focus group discussions with parents and other adults working with children. The interviews were distributed evenly across the five zones of Afghanistan with two-week visits to Kabul, Jalalabad, Herat, Kandahar and Mazar-iSharif. Except in the case of Kabul, interviews were divided between urban and rural settings.

The female consultant was accompanied by a male Afghan research assistant and in each location the team was joined by a female Afghan research assistant. Girls and boys were interviewed in equal numbers. 
The four agencies which commissioned the research specified that particular attention should be paid to children with disabilities, displaced children, working children and child soldiers. These guidelines and the use of focus group discussions gave a bias to the research, so that it does not yield the quantifiable conclusions of a randomised survey, but instead is rich in qualitative findings from particular contexts.

\section{Survival}

Children experience direct threats to their survival from weapons of war which do not distinguish between military and civilian targets. In the face of such direct threats they may continue to live and work in a hazardous environment, or flee in search of security and shelter. The report highlights the risks of mines and unexploded ordnance to young boys in some urban residential environments, to adolescent boys in mined rural areas and to nomadic Kuchi children whose migration routes cross mined areas.

It was striking how in their search for security many children and their families had repeatedly experienced displacement. Internally displaced children were the least likely to know what the future held in store.

After security and shelter, the next concern among internally displaced households was the economic cost of displacement. Both the boys and girls interviewed showed a willingness to contribute to the household economy. It was remarkable and encouraging that, although they were engaged in menial tasks for long hours, children were not homeless or starving. The majority of households did have the wherewithal to make a living: they had assets and skills, and, despite the war and frequently closed borders, the markets continued to function. Displaced households appeared vulnerable in the short-term, but those which had been displaced for longer had developed strategies for survival. However households headed by a person with a disability or a woman continued to be vulnerable: in these households the oldest son had often become an important breadwinner.

As well as depriving millions of Afghans of livelihoods, the war is providing livelihoods for fighters and other beneficiaries of conflict. Economic necessity is one of the engines driving adolescent boys into military units. There is a clear role for international agencies to advocate and support the creation of opportunities for adolescent boys to earn a productive living under the guidance of a skilled adult.

\section{Protection}

Discrimination on grounds of gender has an adverse effect not only on the disadvantaged group, but also on the wider society which is depriving itself of the resources of its excluded members. The research team found a widespread frustration among girls at their exclusion from education. In urban areas there was a similar frustration among women at their exclusion from public employment. All women interviewed were worried by the impact on pre-natal and post-natal care of the Taliban restrictions on female training and employment in the health sector and on female access to health care.

The civic status of women was also seen to have an adverse impact on children living in femaleheaded households. The majority of children who were separated from their families and were interviewed in 'orphanages' were known to have a surviving mother. Both mothers and children, however, insisted on the importance of keeping families together. 
Of the children interviewed, 43 had a disability. There was some evidence that children disabled by war had often suffered many other losses. They and their families seemed to be coping less well with the disability than was the case with children disabled since birth, by disease or by accidents. Discrimination based on disability also created disadvantage for children in households headed by someone with a disability.

Although many Afghans deny that the current conflict is an ethnic conflict, for some children their association with an ethnic group makes them peculiarly vulnerable. The child's group may be championed by a military commander with a personal interest in perpetuating the war. Crossborder minorities may find themselves made the vehicle for the ambitions of the neighbouring state.

An analysis based on gender, disability and ethnicity are indispensable to an overall assessment of vulnerability.

\section{Development}

Children's physical, mental and emotional growth are all affected by armed conflict. However, historically assistance has been directed towards the physical survival and development of children - assistance which promotes their mental and emotional development has been less widespread and is more contentious. To the research team the core issue appeared to be role of the social world and the degree to which it enables survivor populations to manage their suffering, adapt and recover. This entailed a focus upon the collective and not the individual.

The most important site of development for the child is the home. Parents were found to have an acute awareness of their children's suffering and of the stress they themselves were under. They identified economic worries occasioned by war as their main burden, and felt that if this burden were lifted they would be better able to rebuild their own and their children's lives.

It was encouraging to find that not all games and stories had been militarised by the context of war. However, for security, ideological and economic reasons, the opportunities for children to enjoy recreational activities and explore their environment were being curtailed.

A substantial proportion of boys and girls have some access to formal education, often through the mosque, madresseh (religious schools) and home-based religious classes. State-run formal education is closed to girls in Taliban-controlled areas at this time, and across the country is beset by problems of unavailability of textbooks and other equipment, and a crisis in teacher training and salary provision. The interviewed attached a high value to education. Young children saw in it a chance to improve their own future. Adolescent boys and girls saw school as preparing them to contribute not only to their own development but to that of their country.

Another place of learning is the workshop where boys are apprenticed to a skilled adult. Girls were more likely to be learning skills at home.

All in all, the research team was encouraged to find that most children could still point to a positive adult role model. It is the task of agencies working on behalf of children not to supplant but to add to the efforts of parents and other Afghan adults working with children, whether they be the village mullah, the primary school teacher, the skilled male tinsmith or skilled female carpet weaver. 


\section{Participation}

How far adults discussed the war with children varied. However, it was clear that from an early age children discussed the war amongst themselves. They were aware that it intruded upon many aspects of their daily life, ranging from whether it was safe for them to go outside to whether they would have to forgo school and contribute to the household economy. Although radio ownership was widespread, children explained that adults were the main listeners. It appeared that there would be scope for children's programming.

Children's identification with Afghanistan and their perception of the war varied depending on their individual circumstances. The children who most positively identified with their country were those who had been forced to cross the border as refugees. Explanations for the war divided into three categories: the overwhelming response was that leaders were fighting for power and that recruits were coerced to join them. The second category of response was that leaders were fighting for money and that recruits were joining them because they too needed money. The third category of response was that people were fighting for an idea, for Afghanistan or for Islam, and that recruits were joining them voluntarily.

The most articulate respondents to these complex questions were the adolescents. It was disappointing that across Afghanistan the research team found only one initiative by an international agency which was designed to build on the energy and insights of this age group.

\section{Conclusions and Recommendations}

The development of children cannot be put on hold until the permanent cessation of violent conflict. There is therefore a particular urgency to interventions designed to benefit children. This means that agencies working on behalf of children have to be flexible and seize opportunities locally to encourage those factors which promote the wellbeing of children. First and foremost will be safety and security. Next will be support for the efforts of Afghan parents and other adults caring for children, to provide an adequate livelihood for the household, and the routine and example to foster the child's emotional and mental development.

At the same time as providing practical assistance at a local level, agencies have to act in unison at an international level to advocate the prompt resolution of the armed conflict by peaceful negotiation.

Agencies have limited resources and will therefore be selective in their interventions. While an even distribution of assistance should be maintained across the country, the nature of this assistance should be based on a local vulnerability analysis taking into critical account gender, disability and existing conflicts.

This research has confirmed Graça Machel's findings that children are less affected by a sense of hopelessness than adults, and are less polarised in their views. Further research is needed to understand how agencies can better build upon this capacity, and create a climate of optimism. Particular attention should be paid to adolescents, for it is this group which has the potential to lead Afghanistan out of war. 


\section{ACKNOWLEDGEMENTS}

Thanks must go first and foremost to the children and adults who across Afghanistan gave freely of their time to talk with the research team. Although the interviewees have been made anonymous within this report, it should be remembered that each individual spoke with the research team about their personal experience.

Sami Hashemi was an indefatigable assistant throughout the journey. Female research assistants in each location showed courage and commitment to make sure that girls and women had an equal voice with boys and men in this study. Leiluma and Wajiha provided help in Jalalabad and Herat. Shoira joined the team in Mazar-i-Sharif and made an additional contribution to the research through her transcription of the stories and games cited by children.

It is not possible to name all the individuals who provided hospitality and helped open doors for the research team. Instead, below is a list of some of the organisations they came from.

Kabul: Afghanistan Vaccination and Immunisation Centre (AVICEN), Agency Coordinating Body for Afghan Relief (ACBAR), Agricultural and Construction Development (ACD), Aschiana, Norwegian Afghanistan Committee, Save the Children Federation, Inc. (SC-US), Tahia Maskan orphanage, Terre des Hommes (TdH), United Nations Children's Fund (UNICEF), United Nations Office for the Coordination of Humanitarian Assistance to Afghanistan (UNOCHA)

Jalalabad and the eastern zone: Afghan Amputee Bicyclists for Rehabilitation and Recreation (AABRAR), Sandy Gall Afghanistan Appeal (SGAA), Serving Emergency Relief and Vocational Enterprises (SERVE), UNICEF

Herat and the western zone: Afghan Development Association (ADA), Christian Aid, Coordination of Humanitarian Assistance (CHA), Danish Committee for Aid to Afghan Refugees (DACAAR), International Assistance Mission (IAM), International Committee of the Red Cross (ICRC), United Nations Coordination for Human Settlement (UNCHS Habitat), UN High Commissioner for Refugees (UNHCR), UNICEF

Kandahar and the south-western zone: Afghan Development Association (ADA) in Kandahar and Zabul, Guardians, Handicap International (HI), Handicap International Community Based Mine Awareness Programme (HI CBMAP), ICRC, Islamic Movement of Taliban Afghanistan Liaison and Planning Office, Islamic Aid Health Centre, Ministry of Repatriation, Southern and Western Afghanistan Balouchistan Association for Coordination (SWABAC), UNICEF, UNOCHA, World Food Programme (WFP)

Mazar-i-Sharif and the northern zone: Afghan Red Crescent Society (ARCS), Cooperation Centre for Afghanistan (CCA), IAM, Leprosy Control Organisation (LEPCO), Médecins sans Frontières Holland (MSF), Save the Children Fund UK (SCF-UK), SC-US, UNCHS Habitat, UNICEF

Islamabad/Peshawar: Agency Coordinating Body for Afghan Relief (ACBAR) Resource and Information Centre (ARIC), British Broadcasting Corporation: Afghan Education Programme (BBC AED), Rädda Barnen Training Unit, SCF-UK, SC-US, SERVE, UN Comprehensive Disabled Afghans' Programme (UNCDAP), UNICEF, UNOCHA

UK: Bradford University Dept. of Peace Studies, SCF-UK Policy Development Unit

Thanks also to the members of the child-focused agencies group from Rädda Barnen, SCF-UK, SC-US and UNICEF for their support during the research and their comments on the draft report. 


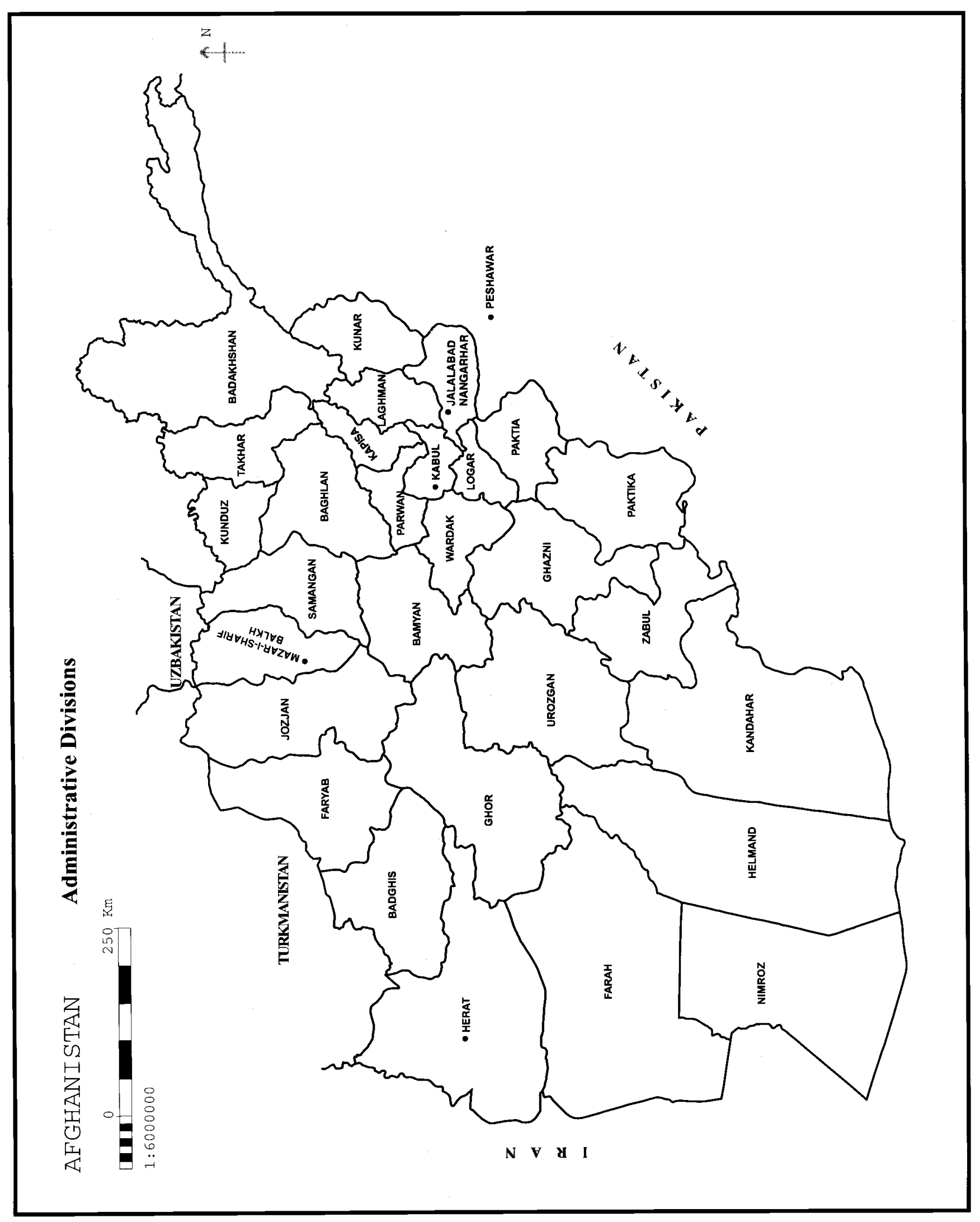




\section{INTRODUCTION}

Four child-focused agencies working in Afghanistan commissioned this study of the impact of conflict on children in Afghanistan. They were three members of the International Save the Children Alliance (ISCA) - Save the Children UK, Save the Children Federation, Inc. and Rädda Barnen (Save the Children Sweden) - and the United Nations Children's Fund (UNICEF). The four agencies seek through their work to make a reality of the rights enshrined in the UN Convention on the Rights of the Child, and have been meeting together regularly to consider the particular implications for their work of the impact of conflict on children. In commissioning this study, this regional working group was inspired by the work of Graça Machel, Expert of the Secretary General of the United Nations on the Impact of Armed Conflict on Children, and her study on the subject published in 1996.

It was recognised that the terms of reference (Appendix I) were ambitious, and that this study was just one stage in a process of improving the agencies' understanding of children's circumstances. The process would also involve action research, as the agencies "learned by doing" in the development of work with children.

Under the UN Convention on the Rights of the Child:

Article 1

For the purposes of the present Convention, a child means every human being below the age of 18 , unless, under the law applicable to the child, majority is attained earlier.

Childhood is a social construct which differs from one society to another. By the age of 18 some young Afghans may be parents, heads of households, military combatants or running their own businesses. Others may be students or confined to the parental home with little decision-making power. This research was an exploration of the situation of all Afghans under the age of 18 , whatever their role in society.

As Graça Machel emphasises, "many of today's conflicts last the length of a 'childhood', so that from birth to early adulthood children experience multiple and accumulative assaults. Disrupting the social networks and primary relations that support a child's physical, emotional, moral, cognitive and social development in this way has profound physical and psychological implications".

Children and increasing numbers of young adults in Afghanistan have no memory of a time when their country was not in a state of war. The armed conflict in Afghanistan has been protracted and no end is yet in sight. What is more, the roots of the war in Afghanistan lie further back in the country's history than a young lifetime, and are not confined to Afghanistan's geographical boundaries. Today's armed conflict is the product of failure to transform these deeply rooted and uncharted conflicts without resort to violence. These unresolved conflicts have arrested the development of health and education services, urban and rural infrastructure, and legislative and judicial systems.

From the findings of this research it could be argued that the war intrudes upon every aspect of civilian life. Children's rights to survival, protection, development and participation are all affected by the continuation of the armed conflict. Some children are still living under bombardment and face direct threat to the right to life; others have survived life-threatening attacks in the past, but still do not enjoy a standard of living adequate for the child's physical, mental, spiritual, moral and social development. 
In this situation all children in Afghanistan can be described as survivors, and it is in their very survival that can be found a nascent sense of purpose, self-esteem and identity. It was the task of this research to explore what has characterised their survival, and to identify those elements of Afghan life which have exhibited continuity and those which have undergone change - it is noteworthy that some changes resulting from the war have opened up opportunities for agencies wishing to work with children. Children were found to have suffered multiple consequences of conflict, but also to have recourse to multiple resources. Any attempt to map these consequences and resources is therefore complex.

The findings are a sum of the experiences of individual children - experiences which have been defined locally and historically, by gender, age, ability and position in the family as well as differing social and economic circumstances. Each child has a different story. This study tries to respect that particularity while at the same time drawing more general conclusions. For example, it was found that children's perception of the reasons for the conflict vary with age, but within the age-groups 6-9, 10-13, and 14-18 and across gender, ethnic and class boundaries, there are noticeable similarities.

The children's stories show that the war has had multiple effects on their lives. The agencies asked the consultant to pay particular attention to the situation of working children, internally displaced children, children with disabilities and child soldiers. However, it was common to find that a child who was displaced also then had to work, or that a young member of a military unit had also been disabled by a mine.

The research team spent approximately two weeks in each of the five zones of Afghanistan. However, they did not spend any time in the remote central region of Hazarajat or the northeastern region of Badakhshan. Each location had its own history and revealed different evidence of the impact of armed conflict. During the period of research there were renewed outbreaks of fighting in the Kabul and Mazar-i-Sharif zones, reminding the researchers that the impact of the conflict changes over time, and varies in intensity from location to location. Nevertheless, across Afghanistan there was a growing disappointment with the outcome of the war against the Soviet occupation (1979-89), and with the subsequent Afghan leaders.

First the leaders were fighting for freedom from the Russians, now they are fighting for power. (Girls aged 13-18, Surkhrud district, Nangarhar province)

Four of the five zones in which the study was conducted were under the authority of the Taliban who have institutionalised a puritanical form of Islam with particularly disturbing restrictions upon women and girls. However, it should not be forgotten that gender discrimination has a long history in Afghan society, and that during the recent years of civil war not only the Taliban, but also other Afghan parties to the conflict, have institutionalised new gender discrimination in the name of Islam. The focus of international agencies must be on the violation of women's and girls' rights and the impact of these violations on children. It would be to divert attention from these violations, if the focus were on the fact that these violations have been perpetrated in the name of Islam. The role of Islam remains and will remain common to the whole of Afghanistan, as well as neighbouring states.

The current restrictions imposed upon women and girls by the various authorities in Afghanistan are alarming because they raise the speculative but disturbing question of the price of a negative peace, i.e. the absence of armed conflict. If one party were to win overall control of the country, and if the armed conflict were to cease, the conflict between discriminatory edicts and practices on the one hand and the human rights of women and girls on the other would remain unresolved. 
This conflict impinged on the research, and was reflected in the responses of the children and adults interviewed.

All children in Afghanistan have suffered directly or indirectly from the war, and will continue to suffer as they grow into adulthood if Afghanistan is prevented from participating in regional economic and trading developments and taking its place as a peaceful member of the international community of states. But the development of children in Afghanistan cannot be put on hold until there is a permanent cessation in the fighting. Factors that promote the wellbeing of children during periods of armed conflict need to be identified and encouraged.

From experience of working with children in a number of war zones, the International Save the Children Alliance has identified some factors which promote the wellbeing of children which seem to be universal:

- safety and security

- sympathetic caregivers (preferably one or both parents)

- familiar routines and tasks (such as school provides)

- interaction with other children (e.g. in play and sports).",

At the same time factors also need to be identified which will enable children, as they grow into adults, to begin to deal with the underlying conflicts that have given rise to the violence. This requires an analysis of the distribution of power which leads to discrimination and violence at the domestic and community levels as well as to national civil war.

This report is organised around the four constituent themes of the UN Convention on the Rights of the Child: survival, protection, development and participation. It aims not only to make a situation analysis of the state of children's rights in Afghanistan today, but also to consider how, within this situation of protracted armed conflict, steps can be taken to make a reality of children's rights in the future. In the section which concludes each chapter examples of good practice, which contribute to making a reality of children's rights, are given. It is a matter for debate whether a rights-based approach is the best way forward within a context where Afghans, unlike citizens of other states party to the UN Convention on the Rights of the Child, have no recourse to their own state representatives. That said, the conclusions of this report are founded upon the undeniable stake that the children of Afghanistan have in a peaceful future. After listening to children across the country with as great an empathy as they could muster, both cognitively and emotionally, the research team were persuaded to take a positive view of those children and their conclusions are therefore optimistic.

Where the word "children" is used this refers to both girls and boys, when only one sex is referred to "girl" or "boy" will be used. 


\section{METHODOLOGY}

The consultant was asked to make a situation analysis and assess children's needs. She was requested to identify examples of good practice in the field of programming for children, and to recommend further areas for investigation. Most important, she was asked to gather her information, as far as possible, from children themselves. Priority was given to the 6-18 age group, 500 of whom contributed through semi-structured interviews, although observations were also made of younger children. The interview schedule for children is included in Appendix II. Focus group discussions were also carried out with parents and other adults working with children.

To assist her in this task an Afghan male research assistant, Sami Hashemi, was appointed and in each location the team was joined by a female Afghan research assistant. Girls and boys were interviewed in equal numbers.

The period of research was four months from June 1997. The interviews and focus groups were distributed evenly across the five zones of Afghanistan: with two-week visits to Kabul, Jalalabad, Herat, Kandahar and Mazar-i-Sharif. In all except the Kabul zone interviews were held in both rural and urban locations.

The four agencies which commissioned the research specified that particular attention should be paid to children with disabilities, displaced children, working children and child soldiers. These guidelines and the use of focus group discussions gave a bias to the research, so that it does not yield the quantifiable conclusions of a randomised survey, but instead is rich in qualitative findings from particular contexts.

The methodology had its limitations: the ethics of research with children are sensitive, and it is a moot point how far these children gave their informed consent when participating in the interviews. As they continued on their journey the research team learned two Dari proverbs which guided them in their questioning.

\section{Don't rub salt in our wounds. (Mothers, Kamaz camp, Balkh province)}

This is a proverb in Dari as well as English. The researchers were wary of giving children and their parents unnecessary pain, by asking them to recount painful past experiences. They did not ask direct questions related to violent experiences, but instead encouraged children and adults to talk about their lives from the starting point of work and free-time, or child-rearing and education, and often the child or adult would then volunteer information related to the war. If the child or adult showed that they wanted to talk, the researchers would show that they were interested; if the child or adult were evidently reluctant to talk they would try and show that they respected their silence.

\section{Only the place where the fire burns knows the heat of the fire. (Sami Hashemi, Research Assistant)}

This Dari proverb highlights a significant limitation of this research. It was not possible for the adults engaged in the research to share fully the experiences of the children. Over the period of research, the research team were influenced by each of the children they met, and were guided by them as to what adaptations they should make in their methodology. From this experience they concluded that there is scope for greater participation by children in future studies, especially if there was a longer term involvement with one group of children. This could include the development of child-to-child research. 
The library search conducted in Pakistan and Afghanistan showed that there was very little information about the lives of children in contemporary Afghanistan. Most of the materials found concentrated on the refugee population in Pakistan. The difference in the availability of information relating to refugee children and the population of children who are displaced within Afghanistan was striking. This difference has also been reflected in the scale of humanitarian assistance that has been made available to each group.

Within Afghanistan a number of studies have been made which are useful contributions to the subject of the impact of conflict on children. Two studies have been made under the supervision of Cindy Dubble for SCF-UK and Terre des Hommes ( $\mathrm{TdH})$ which focus on children working in the streets of Kabul and of Mazar-i-Sharif; these include hour by hour accounts which are a telling description of the daily labours of children. ${ }^{3}$ In Kandahar district, Handicap International has examined the prevalence of polio and war related disabilities. ${ }^{4}$ UNICEF has sponsored a study of the extent to which children in Kabul have direct experience of violence related to war. ${ }^{5}$ These studies are distinguished by their attention to children and the equal participation of male and female researchers.

The research team was guided in the development of its methodology by the assumption that it was necessary to respond to the totality of children's experiences and not to any one particular aspect of those experiences. They wanted to find out not only what were the negative consequences of armed conflict on children, but also what were the positive resources that children had to deal with these consequences. The interview schedule was therefore designed to reveal whether the child had experienced the death of a close relative or the destruction of their home because of war, and also which relatives remained as important caregivers and what activities provided structure to the child's day. Questions about activities were put in the context of whether the children undertook these activities alone or in the company of others. The research team wanted to map the support networks available to children, whether amongst siblings, cousins, other children, parents, adult relatives, or other adults. From the children's responses they hoped to be able to identify those children in the most difficult circumstances and most vulnerable to the negative consequences of war.

There were a number of open questions about complex issues (see Appendix II). These open questions yielded varying responses. The breadth of views put forward by children demonstrated the potential for exploring complex issues such as children's perception of the reasons for war, adult role models, future aspirations, and national identity. The researchers kept to a semistructured interview, which enabled them to omit questions when they did not seem appropriate, and to develop areas of interest appropriate to younger or older children.

Pilot interviews were made among children of different ages in Kabul. Thanks to the suggestions of children, and Afghans who had worked closely with children, the researchers were then able to see how ambitious they could be in touching on the complex issues mentioned above, and also to recognise the significance of a number of social activities they had originally neglected. Story telling was discovered to be important for many children. So too was their participation in special occasions such as picnics, visits to shrines, wedding parties and religious festivals.

The researchers were aware in advance that they would be required to work in different languages and interviews were undertaken in Dari, Pashtu and Uzbek, as well as Afghan sign language. ${ }^{6}$ More difficult, were the different nuances in children's as opposed to adults' language, and time was needed to acclimatise to the children's vocabulary in each locality. 
This was not a survey designed to yield quantifiable data representative of the entire population of Afghanistan. Instead, an attempt has been made to be as transparent as possible about the selection of who was interviewed, and to discuss the particular biases in the sample. Children were often selected because of their connection with an organised activity, whether an NGO programme or a home or mosque-based school. The report needs to be read not for quantifiable conclusions but for qualitative information set within context. Having said this, it has also begun to identify patterns and trends which it is hoped further research will investigate more fully.

The four agencies who commissioned the research specified that particular attention should be paid to children with disabilities, displaced children, working children and child soldiers. This brought a deliberate bias to the sample interviewed since the researchers were deliberately seeking out children from these categories. It was the concern of the researchers to find children wherever they were, and to learn about the range of circumstances in which children live.

In order to enter the children's homes it was vital to have a female researcher. For example, in the city of Jalalabad the Afghan male research assistant interviewed three brothers with hearing impairments. It was not possible for him to enter the compound: the family was poor and had no second room in which to welcome guests. The interview with the boys therefore took place under a tree just outside the entrance. In the meantime the female consultant was able to enter the compound and talk with the family in their one-roomed dwelling.

Peer group interviews of five or six children who were as far as possible of the same age and gender allowed children to feel more at ease, but also risked lending weight to a consensus view. Once the most vocal child had given an answer the others in the group were likely to echo this response. Group interviews could also reveal interesting disagreements, as when one seven-year old boy, a resident of the Mazar-i-Sharif marastoon (orphanage), said that he hoped his own children would grow up to be commanders and the rest of the boys in the group promptly asked him to revise his view.

Children have different attention spans, but no child or adult can maintain the same level of concentration over an hour-long interview. The researchers therefore built in changes of pace and activity. At all times it was made clear that children were not obliged to respond. Often they were keen to continue.

We're not tired, it is our mouths that are doing the talking. (Group of boys aged 8-13, Jalalabad city)

The researchers were limited by the fact that, with few exceptions, they had only one encounter with each child. Sometimes they were helped by an introduction from someone already wellknown to the child, but on other occasions sufficient trust to enable the child to provide information with confidence had to be built up over one interview. Only in one location, the Uzbek speaking enclave of Andkhoy in Jowzjan province, were there difficulties in gaining access to children because of mistrust.

The consultant observed the majority of the interviews, and was able to become an active participant on occasion through her knowledge of the Dari language. Her presence as a foreigner will have added to the artificiality of the interview situation. However, all members of the research team were to some extent outsiders to the children. The interaction between the researcher, as outsider, and the children was critical to their responses. Two female assistants 
proved very popular, and whether by way of a compliment or out of respect children would say by the children turned the tables and when asked what questions they had for the interviewer quizzed the adult about their childhood.

As well as gaining information through interviews, the researchers relied on observation. The economic circumstances of the child were often estimated after observation of the condition of the household furnishings. More critically the researchers were able to observe children's activities which the children had omitted to mention in the interviews. No child mentioned that they played so-called war games in their free-time, but many boys were observed to be engaged in games with toy guns or involving two teams named after opposing parties to the war.

To supplement the information gained from group interviews, several more detailed individual interviews were made. These case studies allow a fuller understanding of the history of the child (see Appendix IV).

In order to gain a greater understanding of a particular aspect of children's experience, focus group discussions were held. For example, discussions were held with teenage boys and teenage girls about the experience of returning to their homes in Zindajan district, Herat province after passing their childhood as refugees in Iran.

Of secondary consideration to the researchers were the many contacts they had with adults. Often the adults acted as gatekeepers for the children. The researchers found that the main obstacle to interviewing children was the interest of adults. Adults wanted to tell their stories. On a number of occasions the researchers had to listen patiently to the litany of the grandmother, or the aspirations of the local commander, before being able to give their undivided attention to the children.

Sometimes the researchers sought additional individual information from individual adults, such as the munchi who organises the roster of boys working washing cars. More often the researchers would meet for discussion with a group of men or women. These adults usually were not strangers to each other and the discussion revolved around their role as parents, or people working with children. Again within each group it was found important to have an understanding of the relationships within the group. For example, some teachers were comfortable speaking in the presence of their headteacher, others were not. Some of these discussions were illuminating with regard to child-rearing practices, and the adults' perception of changes in childhood.

The researchers also sought out examples of elements of good practice in programming for children. They tried to learn how a programme had begun, what obstacles there had been to its development and how these had been overcome. Those children's programmes which have been selected as demonstrating elements of good practice recognise that families and communities have often been fragmented and weakened by armed conflict and "focus on supporting survivors in their efforts to heal and rebuild their social networks - that is enhancing people's ability to help themselves". They have also all striven to ensure equal gender access. 


\section{SURVIVAL}

Article 6

1. States Parties recognise that every child has the inherent right to life.

2. States Parties shall ensure to the maximum extent possible the survival and development of the child.

The first theme to be discussed here is that of survival. Children experience direct threats to their survival from the weapons of war which do not distinguish between military and civilian targets. In the face of such threats they may continue to live and work in a hazardous environment, or flee in search of security and shelter. At the same time they are all preoccupied by the need to buy food. If their parents do not have the financial capacity to provide for them, then children may be obliged to work. This study confirmed the findings of other research ${ }^{8}-$ that those children engaged in long hours of menial labour were most likely to be from families which had been recently displaced, or which were headed by a person with a disability or by a woman.

\section{War fatalities}

\section{Article 38}

1. States Parties undertake to respect and to ensure respect for rules of international humanitarian law applicable to them in armed conflicts which are relevant to the child...

4. In accordance with their obligations under international humanitarian law to protect the civilian population in armed conflicts, States Parties shall take all feasible measures to ensure protection and care of children who are affected by an armed conflict.

Children in Afghanistan die as a direct consequence of the war. They die in aerial bombardments and rocket attacks, from bullet wounds and mine explosions. They may be more vulnerable than adults to these direct impacts of war. It is suspected that mine attacks which an adult can survive will often be fatal to a child, because vital organs in a child's smaller body are closer to the blast and less well insulated by muscle and fat. ${ }^{9}$

Fatalities are often unrecorded nevertheless throughout their journey the research team were reminded by the survivors of those who had died. Of the children interviewed, 290 or nearly sixty percent spoke of a relative (defined as siblings, parents, grandparents, uncles, aunts and first cousins) who had died because of the war. This proportion may be higher than that found in a random sample because of the research team's use of group discussions where children in similar circumstances were gathered. Here are the stories volunteered by a group of five boys, interviewed at a centre for street and working children in Kabul.

My cousin was walking on Bibi Mahro hill with her mother. A mine exploded, she was killed and her mother was injured.

My father was on the way to Charasiab with my younger brother when he was taken away by armed men. His eyes were removed, his legs were cut off, and after months of searching his body was found and buried.

Five years ago a rocket killed my father and his face was completely destroyed.

My cousin was killed by a rocket.

One of my cousins was killed by a mine. When his father went to collect the body another mine killed him.

(Boys, aged 7-11, centre for street and working children, Kabul) 
These five boys had escaped from the fatal consequences of war and could tell the stories, but an escape one day is no guarantee of an escape the day after. These five children, and others like them, have to become survivors day after day. Many of them may be living and working in high risk environments. The risks vary from location to location, and they are generally higher for boys.

\section{Hazardous environments}

In Kabul, residential areas of the city are hazardous because of unexploded ordnance (UXO) and landmines. Boys are more likely to be outside their homes than girls are. They may be playing in derelict areas or trying to glean a living for themselves and their family from what scrap metal is to be found. Save the Children Federation, Inc. collected data from the city of Kabul's ten major hospitals and some health clinics, as well as through visits to selected communities, for the period January-June 1997 . They found that $71.5 \%$ of all UXO victims and $52.6 \%$ of all mine victims were male and under 18 years of age, and just $10.2 \%$ of UXO victims and $5.3 \%$ of mine victims were female and under 18 years of age.

Adolescent boys experience different risks to those of younger boys, and for this reason some data collection for mine victims has been separated by age using a cut off point of 15 years. In their household survey in Kandahar province, Handicap International found that of the males with motor disabilities, $15 \%$ were caused by landmines and an additional $23 \%$ were caused by war. Among the females only $4 \%$ of those with motor disabilities were caused by war, and none were caused by landmines. In this survey the vast majority of the victims were over 15 years of age. The data of mine victims returned to the UN Demining Office in Kandahar shows what the victim was doing at the time of the accident. Males in the 15-18 year old bracket are likely to have been engaged in such activities as irrigation of land, canal cleaning, cultivation, and driving. Younger boys are likely to have been playing, often in groups, or minding animals.

The nomadic Kuchi people, whose pastoral livelihood depends on their animals, are particularly at risk. Although their migration routes are well known, they move across tracts of uncultivated land and the demarcation and demining of hazardous areas on the routes is a formidable task.

When I was younger I looked after sheep. For the last three years I have been able to look after my family's 18 camels. I take them to graze in the bushy areas and lead them to water, in the evening I bring them back and hobble them near the tents overnight. In three years I have only ever lost one camel. My older brother had an accident with UXO and injured his abdomen. He now is only strong enough to look after sheep. My cousin lost his eye in a mine explosion. (Boy, aged 16, Kuchi encampment, Daman district, Kandahar province)

These children, who have had a close escape from the fatal consequences of war, are likely to face other challenges to their survival. The war may have deprived them of shelter or their household's traditional source of income.

\section{Security and shelter}

Article 27

1. States Parties recognise the right of every child to a standard of living adequate for the child's physical, mental, spiritual, moral and social development.

Over half the children interviewed also reported that their homes had been hit or destroyed during the war. Even if the house was not destroyed the child's home was no longer a safe haven, and if 
it was destroyed it could no longer provide adequate shelter. This direct consequence of war then sets in train a history of displacement and additional stresses upon the child and their family.

As Graça Machel points out: "The protection and assistance needs of the internally displaced are similar to those of refugees in nearly all aspects, and yet their situation can be worse, particularly in terms of their legal protection. While refugees have often moved outside the 'war zone', internally displaced persons usually remain within or close to the scene of the conflict, and they are often likely to be displaced repeatedly."10

This was the experience of many children fleeing Kabul after the fighting that broke out in 1991.

We were at home in Karte Naw in Kabul when a rocket landed in our house. My mother was injured and she is still not fully recovered. We left our house and went to the west of Kabul on foot. Fighting continued so the same day we moved with our belongings to Karte 4. After four days in that house we found a truck and travelled to Mazar. From Mazar we went to Herat and then to Iran, where we stayed for one month. We then returned to Mazar and travelled via Pulikhumri back to Kabul. When fighting broke out again in Kabul we left for Kunduz and now we are in Mazar again.

(Boy, aged 11, Kamaz Camp, Balkh province)

Having escaped from the house under direct attack, not everyone survives the flight away to safety.

When we left our house we had to cross the river Morghab, and my brother was drowned. He was ten. (Girl, aged 13, Ghara Kalei camp, Kandahar province)

When we left Morghab we fastened my brother, who was one year old, on the back of a donkey. On the way he got cold, and by the time we arrived in Herat he was dead.

(Boy, aged 10, Rawza Camp, Guzara district, Herat province)

People on the move are first and foremost seeking safety, but they also require adequate shelter. The most memorable experience of a child living in Kamaz Camp was of the big storm that, within a year of its establishment, hit the camp set up for the displaced from Kabul.

The rain came; water entered the tents and washed everything away.

(Girl, aged 8, Kamaz camp, Balkh province)

In the camps for IDPs in the centre of Herat, mothers had organised the limited space meticulously, but they complained that they did not have the means to keep their tents free of mosquitoes and fleas.

IDP fathers from Badghis, who had settled in an abandoned village south of Kandahar, were worried that they would not be able to provide their children with proper shelter during the winter. At the time of the research the main problem was shade from the sun, but in winter shelter would be required from wind and rain.

In 1997 in Kabul the fighting to the north of the city between Taliban and the forces of Massoud had pushed families out of Kapisa, Parwan and Kohestan provinces. The families sheltering in a school in Khair Khana district, Kabul had been told to vacate their lands by the Taliban in December 1996, and had not yet been given permission to return. The children told the research team how their village was bombarded and they crossed the mountains on foot and 
sought refuge in Kabul. In Kabul they had not been provided with camps and had been unable to find affordable rented accommodation. They had left their village with only the clothes they were wearing. There was a well in the schoolyard for water but as for food.

We all have to go out and beg. If we find food for lunch then we are worried about dinner. Sometimes we have food and sometimes we don't.

(Girls aged 10-13, Khair Khana district, Kabul)

In June 1997 families were on the move from Chorbulak Orteppe village, near Balkh.

Houses were destroyed and looted. The women and children fled, and we came here where it was peaceful and we could go to school. (Girl, aged 11, Balkh, Balkh province)

Travelling round the country, the research team gained the impression of a population tormented by the war, with little choice whether they stayed put or moved on. Time and time again people had had to remake their homes. The researchers asked all the child interviewees whether, if the research team were to return in a year's time, they could find the children in the same place. IDP children were the least likely to know what the future held in store for them. Even if their new homes withstood the weather and the test of time, they were still characterised as temporary: IDPs referred to the houses they had built of mud-bricks as tents.

\section{Financial capacity of parents}

Article 27

2. The parent(s) or others responsible for the child have the primary responsibility to secure, within their abilities and financial capacities, the conditions of living necessary for the child's development.

If, after security, the first concern of IDPs was for shelter, they were preoccupied also by the economic costs of displacement. For those IDPs who were not able to salvage possessions, the cost of displacement may be acute. It may become beyond their financial means to move back to their original home, even when they felt it was secure to do so.

The Hada Farm camp on the outskirts of the city of Jalalabad was set up in 1992 for IDPs from Kabul. It is now partly empty, but the remaining residents were keen to talk with the researchers. Of the 17 children interviewed in the camp, the fathers of seven were dead. When discussions were held with a group of six women, only one claimed that her husband was present and in good health, two said that their husbands were sick, and three were widows. Further investigation might well reveal a high incidence of female-headed households among those families remaining in the camp. One woman used to work in a factory, but such opportunities for women to earn a living had decreased since the take-over of Jalalabad by the Taliban. Mothers and children gave as their reason for remaining in the camp their inability to afford to move elsewhere.

Other families displaced from Kabul who have settled outside the camps also do not have the means to return to the capital.

When the fighting started our house in Dashti Barchi in Kabul was looted. We went to the north, came back to Kabul, but again the fighting started. This time we left for Jalalabad. My mother is sick and we do not have enough money to return to Kabul.

(Boy, aged 15, Surkh Rud District, Nangarhar Province) 
Other children have returned to their homes, only to find that their families do not have the resources necessary to rebuild them.

Since we returned from Iran, we have been staying with neighbours and feel ashamed. Everyone asks why we have not rebuilt our home, but our father has no work, and therefore no money to rebuild the house. (Girl, aged 16, Enjeel district, Herat province)

Poverty is a major obstacle preventing parents from securing the conditions of living necessary to safeguard their children's survival. Although neighbours do help out, and many IDPs move in with relatives, IDP families are more likely to be cut off from extended family networks. This contributes to the distress of parents.

Our hearts are not calm as long as we are worrying about other family members left behind in Kabul. (Mother, CTC camp, Herat)

It also increases their financial hardships: not only are they cut off from savings which may have been in the form of capital assets, they are also cut off from people that they would usually borrow from, or begin a financial venture with. As IDPs settle in camps, or in between settled communities, they may find themselves excluded from the traditional sources of financial support open to poorer members of Afghan society. The IDPs were one of the groups targeted by the Group Guaranteed Lending and Savings Scheme (GGLS) run by Save the Children Federation, Inc. in Balkh and Jowzjan provinces. Through the GGLS women gained access to financial capital, were encouraged to save, and also were linked with a group of borrowers. So far there was no evidence that IDP households were less reliable borrowers than other households.

In a situation of displacement adults may also find that they are deskilled.

Each time we move from one area to another, I lose my job. This affects the whole family not just me. I know they are all thinking that their father has no job. I cannot speak with anyone. I pass my time in front of the tent. Twenty years of war would affect a body made of stone, but I am made of flesh and blood...(Father, CTC camp, Herat)

\section{I used to be the director of a government department. Now my children are working on the streets near the Rawza shrine. (Father, Kamaz camp, Balkh province)}

Those adults who have work do not find it pays them enough to support their families. Teachers in Rawza Bagh camp, Herat province described how they went straight from their classes to collect brushwood for fuel.

Families are also facing difficulties in the Taliban controlled areas of Afghanistan because of the bar on work for women. This is especially damaging for female-headed households, and some women are driven to beg on the streets.

The staff of the marastoon (orphanage) in Mazar-i-Sharif described how in August 1997 Balkh television had broadcast the case of two brothers, one of whom was working with the government and was able to provide his children with good clothes. The poorer brother was staying with his wife and children in his richer brother's house. He had found his poverty so galling that he killed his own three children, and then killed himself after informing his neighbours that no one should be blamed, and that he was responsible for his children's deaths. 
Such deaths are exceptional, and the researchers were unable to confirm other rumours of parents trafficking or killing children. However, the spectre of poverty is real, and pressures upon parents intolerable. The scarcity of paid work for adult men, the authorities' bar on work for women, and the long working hours necessary to earn a living wage, all drive parents to encourage their children to supplement the family income by engaging in long hours of menial labour.

\section{Working children}

\section{Article 32}

1. States Parties recognise the right of the child to be protected from economic exploitation and from performing any work that is likely to be hazardous or to interfere with the child's education, or to be harmful to the child's health or physical, mental, spiritual, moral or social development.

First it is important to consider what is meant by 'working children' within the Afghan context. All the children interviewed for this study, with the exception of children living in institutions, identified daily activities which they described as work. Often they found it much easier to talk about work than to say whether they had any free time and if so what they did with it. Work was for them a normal and appropriate activity. The majority took pride in their contribution to the household economy either through productive work such as a paid apprenticeship or household work such as looking after younger siblings, and they appreciated the opportunity to acquire skills that would be useful in their later lives.

This sense of responsibility and willingness to participate in their family's survival was as evident amongst girls as among boys. It is a reflection in the decline in the standard of living of Afghan households of different economic classes that children from comparatively wealthy households also wanted to contribute to their family's income. In a spacious walled compound in Surkhrud district six adolescent girls were interviewed. Their father had not given them permission to go to school, and they did not now expect to leave the compound until they married. Only younger girls were able to visit neighbours and the bazaar. They managed the housework very efficiently between them, to the accompaniment of Hindi music tapes, and had free time for embroidery.

\section{Please find us a market for the embroidery we do at home. We want to earn money because our men are jobless. (Girl, aged 18, Surkhrud district, Nangarhar province)}

Other girls who were attending school also supplemented the family income. In Andkhoy, Jowzjan province, girls were busy with carpet weaving as well as their studies, and in Mazar-iSharif schoolgirls were being paid for making the smocking for the chadri (all enveloping gown) worn by the townswomen. The work done by girls is less visible than the work done by boys, because it is usually performed within the home. Within the house, there was a hierarchy of tasks for younger and older girls, with younger girls being involved with collecting water, washing tea glasses, and caring for small siblings, and older girls being involved with food preparation, breadmaking, cleaning the house and washing clothes.

Small boys were also busy with collecting water and looking after younger siblings, but older boys were unlikely to do any domestic work. In rural areas boys were busy tending animals, cultivating or selling crops, or helping out in the mill. Often they had considerable responsibility. This was one of the stories that a teenage boy told of his life as a shepherd before he lost his foot in a mine explosion. 
Three years ago my brother and I went with about ninety animals a long way from the village. It began raining and thirty animals were swept away. When darkness came I lost the other animals. As I ran back to the village I fell on the uneven ground. My relatives came to help, but about half of those animals belonged to neighbours. After that I always kept the animals near the village. (Boy, aged 17, Mazar-i-Sharif, Balkh province)

In urban areas boys were more likely to be engaged in apprenticeships in bicycle repair, tin smith or metal welding workshops, or casual work selling things on the street, polishing shoes, or washing cars.

The researchers' observations of children at work were during the school holidays. In Mazar-iSharif some boys had taken the opportunity offered by the hot weather and the school holidays to sell cold water on the streets but they would stop once the weather grew cooler and the schools reopened. However, in all other locations the researchers were assured by children that work was often combined with attendance for two to three hours at school. Some of those boys and girls interviewed who were engaged in work under the supervision of an adult explained that the hours of their apprenticeship were adjusted to allow them to attend school classes.

There was also a minority of Afghan children who were working under conditions that were harmful to their education and development. However, even these children were not street children as observed in other country situations. They all had homes and were working to bring home food. ${ }^{11}$

Children in Kabul were engaged in the hazardous task of collecting scrap metal in areas where they were vulnerable to mines and UXOs. Boys all over the country were also observed at work in crowded metal workshops without visors. Children on the street were also vulnerable to harassment and abuse.

One early morning I was in the street and a man asked me to come into his house to burn my incense there. After I had entered the house and burned the incense in the rooms I asked him for payment. He forced me out of the house, and hit me in front of strangers as well as my friends on the street. He was shouting "Get this boy away from me, I don't owe him anything." He knocked the tin of hot coals out of my hand and burned my ankle. (Boy, aged 11, Kabul)

This boy was still suffering from the burn on his ankle when he was interviewed.

Children were also found working in less hazardous circumstances but for excessive hours that allowed no time for study or recreation, and little time for rest. Girls in the Aschiana centres in Kabul described how they disliked collecting paper for fuel and how, even after a long day's work, they still fell asleep at night feeling hungry. Across the country some girls complained of excessive housework, however these girls were all only daughters and had no sisters with whom to share their tasks.

Parents and children valued the chance to work and acquire a skill more highly than time spent begging or selling cheap items on the street. The majority of the children interviewed who were trapped in the performance of such undervalued tasks were IDPs, such as this boy from Badghis who was selling soap and toothbrushes from a cardboard carton.

I only go home at night, and have been on the streets since early morning and have not sold anything. I do this job because my father is away since it is harvest-time back in Morghab and I have to earn money for my mother and two sisters. I don't know how to do anything else. This is what other people do too. (Boy, aged 10, Jarde Walyat district, Herat) 


\section{Economic necessity and participation in military units}

Article 38

2. States Parties shall take all feasible measures to ensure that persons who have not attained the age of fifteen years do not take a direct part in hostilities.

3. States Parties shall refrain from recruiting any person who has not attained the age of fifteen years into their armed forces. In recruiting among those persons who have attained the age of fifteen years but who have not attained the age of eighteen years, States Parties shall endeavour to give priority to those who are oldest.

One of the more hazardous occupations in which children can engage is to join a military unit. Although it is often said that child soldiers are prevalent in Afghanistan ${ }^{12}$ the research team did not find substantial evidence of children under the age of 15 in the armed forces. Of the nearly five hundred children interviewed, only 74 mentioned boys between the ages of 15 and 18 who had been recruited. Numbers were higher in Kabul, Jalalabad, and Mazar-i-Sharif than in Herat and Kandahar. The boys were brothers, cousins or neighbours, and although children were not always able to give accurate ages they did know whether the boys were older or younger than themselves and whether they were still without beards. From this sample, less than ten knew of children estimated to be aged less than 15 who had been recruited. ICRC staff working in the hospital in Kandahar treating war casualties had not noticed children under 15 among the casualties.

Economic necessity is just one of the reasons that pushes boys into the armed forces. Those boys who join a military unit reduce the number of mouths to feed at home. Even if a young man is not receiving any payment in cash from his commander, he and his family know that he will be fed and clothed. The majority of these young recruits mentioned by the adults and children interviewed were taken by force by a local commander, and a smaller minority were volunteers. This phenomenon can be seen in terms of the disproportionate flow of economic resources to the military. In peacetime these resources might be allocated to social services. In the meantime military units which have access to transport, information networks and influence, as well as financial resources, may provide social services. The following case is an example of this:

The interviewee was a beardless teenager who was billeted with the Taliban checkpoint in Qalaat. He had been in a mine accident two years earlier, and since then had not been able to work for his family as a shepherd. He wanted to go to Kandahar to seek help for his foot from the hospital but in the meantime he had joined the military unit. He was being provided with food in return for preparing tea and cooking for the Taliban. The commander had given him a waistcoat, and the boy hoped that he would also be able to give him a lift in a vehicle to Kandahar. The previous year he had worked at the Qul Urdu military base in Qalaat as one of the armed guards. He had carried a kalashnikov despite his disability.

There is much anecdotal evidence that before 1993, under the mujahidin, there had been greater recruitment of very young children but this is hard to substantiate. Another interviewee had joined a mujahidin unit aged six, when he was barely tall enough to reach the pipe of the hubble bubble. He had left the unit addicted to hashish, and then had a series of misadventures involving kidnapping and escape. By the time he was interviewed in Kandahar he was at least ten, back with his family, and wanted to become a motorcycle mechanic. He was working under the supervision of a trainer who had persuaded him to stop smoking. The creation of alternative economic opportunities for boys would be one step towards deterring boys from joining military units. 


\section{Making a reality of children's rights to survival}

While the war provides livelihoods for fighters and other beneficiaries of the conflict, it also destroys livelihoods for millions of others. Security, shelter and the economic means to buy food: these were found to be the keys to survival following a direct attack on the household. The children of those households, which had been displaced by war, showed resilience, but their life now had a temporary character. The war had taken away from them and their parents their ability to predict the future: their home was now temporary, opportunities for work for their parents were casual, and the children were passing their childhood in drudgery. It was amongst the IDPs that the research team found least hope.

\section{It is better to be busy or to be asleep, than to have time to think about the future. (Mother, Hada Farm camp, Jalalabad)}

Set against this disturbing picture, filled with the experience of death, injury and displacement, is the remarkable and reassuring fact that within Afghanistan nearly all children have a home. By 'home' is meant a group of relatives with whom to share food and a material shelter. The very few children who were homeless were found seeking shelter at the mosques. It was also striking that children were not starving. The majority of households did have the wherewithal to make a living: they had assets and skills, and despite the war and frequently closed borders the markets continued to function. Displaced households appeared vulnerable in the short-term but longer term IDPs were seen to have developed strategies for survival. Those who appeared particularly vulnerable long-term were households headed by a person with a disability or a woman. In these households the oldest son may become the most important breadwinner. He and his brothers may also be tempted through economic necessity to join the armed forces. There is a clear role for child-focused agencies to advocate and support the creation of opportunities for these boys to earn a living under the guidance of a skilled adult.

Without ever forgetting those who had died, the survivors were helping themselves regain control of their lives, and counteract the unpredictable forces of war that tormented their households. Children repeatedly proved themselves resourceful and committed to the wellbeing of their own families. Older siblings were often among the prime carers for young children, and older children were also making a significant contribution to sustaining the household economy. Any interventions should be designed to add weight to the survivors' own efforts to build a predictable future.

The Aschiana Centres for Street and Working Children in Kabul are a good example of an initiative which has integrated the survival strategies adopted by families in the development of its own programme of assistance. The first centre opened in 1995 with 100 children in response to the visibility of displaced children working in the streets in Kabul. Family workers made contact with the children and their families. The conditions for entry to the programme were that that the children should be working, not in school, and from displaced families. Priority was given to families who had also suffered war injuries or lost relatives.

The Aschiana Centres in Kabul provide children working on the street with a refuge where they have access to a hot meal, washing facilities and medical treatment, and where they can study for two to three hours. The centres recognise the importance of the children's income to their families, and the meal and other facilities provided compensate the children for loss of income while they are studying. Aschiana staff keep in regular touch with families as well as paying close attention to the progress of individual children. 
Aschiana has been able to expand to open four centres serving 700 children because of a unique partnership with an international agency, Terre des Hommes $(\mathrm{TdH})$. While TdH provides administrative support and manages relations with international donors, the Afghan organisation, Aschiana, designs and develops the programme for the street and working children, and manages relations with the Kabul authorities.

The success of such organisations as Aschiana often relies upon dedicated Afghan individuals who can combine compassion for the children of Afghanistan with the political skill to act as their advocate. To rely on the goodwill and political acumen of an individual may be a precarious base for an organisation, but it is the example of such individuals that will give others the confidence to follow suit. 


\section{PROTECTION}

Article 2.

1. States Parties shall respect and ensure the rights set forth in the present Convention to each child within their jurisdiction without discrimination of any kind, irrespective of the child's or his or her parent's or legal guardian's race, colour, sex, language, religion, political or other opinion, national, ethnic or social origin, property, disability, birth or other status.

2. States Parties shall take all appropriate measures to ensure that the child is protected against all forms of discrimination or punishment on the basis of the status, activities, expressed opinions, or beliefs of the child's parents, legal guardians, or family members.

The second constituent theme of the Convention is that of protection, and in this chapter the issues of gender, disability and ethnicity will be explored, as well as the particular circumstances that separate children from their families and place them in institutional care. The survival rights of the child have largely been discussed in terms of threats to the survival of the household or those adults and children who share shelter and food; Article 2 of the Convention again illustrates the way in which the rights of the child and his or her parents are intertwined. In this chapter it will be necessary to have an understanding of the child and the parents, as well as an additional understanding of the disadvantaged group to which they belong and the advantaged group from which they are excluded. It is in this area of the report that the tension inherent in any dialogue between the Western tradition of individual human rights and the Islamic tradition of the umma or Islamic community will be most apparent.

Discrimination may already have been at work before the child's birth. Discriminatory attitudes and practices that put children born into certain groups at a disadvantage are not necessarily a direct consequence of armed conflict. However, during a period of armed conflict communities and households are more likely to be weakened through death, displacement, disease and loss of economic capacity. This means that children may be deprived of their immediate sources of care and protection. The need for protection increases for all children, and those children who are already at a disadvantage may find their disadvantage exacerbated.

During a period of armed conflict warring parties may assert their role as protectors of particular groups. For example the Taliban explain their gender policies in terms of safeguarding the security of all female Afghans, and all parties to the conflict are increasingly being perceived as the champions of particular ethnic minorities. Those with the power to offer protection may not necessarily be the best guarantors of the group's right to development and participation. Members of the group concerned may have taken no active part either in defining their own interests, or in the identification of those interests with the warring party.

In this scenario children may be at a double disadvantage. They are vulnerable as children requiring the protection of adults, and they may be vulnerable as members of disadvantaged groups, which do not have the power to define their own interests or determine their own development.

\section{Children and gender discrimination}

Without exception, mothers and fathers across Afghanistan said that if they could have only one child then they would choose to have a boy. The reason most often cited was that it was customary for the girl to leave the family when she got married, and that the boy would stay at home and provide for his parents. Mothers and fathers did value their girl child as a second child, 
and mothers often cited the presence of daughters as making their own tasks in the home much lighter. Daughters also had an economic value. Part payment could be made for a promise of marriage to a young girl, who would only join the boy's household after reaching puberty.

\section{When there was an epidemic among our flocks, we raised the money to pay for replacement stock by selling our daughters. \\ (Grandmother, Kuchi community, Daman district, Kandahar province)}

Parents differed from home to home on the value they placed on literacy and other formal education for their daughters. If they did attach value to learning which girls acquired outside the home, it was so that they would become better mothers, be able to contribute to the family income, or be able to contribute to society by joining professions where they would care for children or the sick. While there are variations from home to home and within urban and rural areas, people in Afghanistan, like other people in Central Asia, have internalised cultural roles for girls and boys that last from birth to the grave.

\section{My son will bury me and my daughter will weep. (Father, Kurgan Teppe, Tajikistan)}

These gender roles were not invented by the Taliban, but what the Taliban have done is elaborate their particularly rigid interpretation of this tradition, institutionalise the gender roles, and make the state responsible for the punishment of transgressors. The extent of the initial public support for their movement can be explained by the fact that the movement is structured around co-opted elements of Islam and traditional Pashtun culture which people had internalised already.

Other parties to the conflict have adopted similar policies. Recruits are rallied behind these policies and the measure of control over women and girls has become a measure of the parties' success in establishing their authority. For example, when the forces of Abdul Malik took control of Mazar-I-Sharif in May 1997 one of his first moves was to impose additional constraints upon the employment of Afghan women in international offices and on coeducation.

Kabul women understood that as the Taliban experienced setbacks at the frontline, they would reassert their authority over the civilian population by issuing new and stricter decrees. At the time of the research team's visit to Kabul the Taliban were losing ground to Massoud's forces, and women complained of increased harassment.

Taxis carrying women passengers are being stopped more frequently. Six women were in one taxi, and the driver had agreed to lie and say he was a relative. Still the women were asked to get out of the car. They were all wearing the full chadri with their faces covered but one was wearing sandals without stockings. She was beaten.

(Female health worker, Kabul)

Here there was an apparent conflict between the taxi driver, who was willing to break the rules and transport women who were not accompanied by a male relative, and the zealous Talib who stopped the car. However, it was against the woman without stockings that the Talib used his authority to legitimise violence. Incidents of girls as young as eleven years old being harassed for not wearing the chadri have also been reported

Discrimination does not have an adverse effect only on the disadvantaged group. A society based on exclusion is depriving itself of the resources of its excluded members. One of the most contested sites for the imposition of Taliban gender policies is the health sector. 
Article 24

1. States Parties recognise the right of the child to the enjoyment of the highest attainable standard of health and to facilities for the treatment of illness and rehabilitation of health. States Parties shall strive to ensure that no child is deprived of his or her right of access to such health care services.

The Convention on the Rights of the Child also identifies the importance of appropriate pre-natal and post-natal for mothers. Midwives working at the Malalei hospital in Kabul were worried by the increasing restrictions imposed by the Taliban authorities on women's access to health care, and deeply concerned that there were no women being trained to be future health personnel.

This girl wanted to be a nurse.

I had enrolled at nursing school when the Taliban took control of Herat. The Taliban did not force women to leave the school they just said that we could only study if we stayed in the hospital twenty four hours, and did not go back and forth to our homes. My parents would not agree to this. I didn't want to live in the hospital and nor did any of the other female students. (Girl, aged 18, Herat)

Female staff of a Health Centre in Kandahar explained how few female health personnel were left in the city. Other qualified women had left for Pakistan, Germany and the USA during the war.

Female staff of an Afghan NGO working for people with motor disabilities were frustrated by the strict rules they had to endure as they go about their work. They could not travel to work in the company of an unrelated man, they had to wear the full chadri and occupy separate premises from the male staff. This latter rule has meant that the international NGO, which supported the Afghan NGO, has had to finance substantial structural changes to Kandahar hospital building.

In September 1997 the Taliban announced a policy of centralising female health care in Kabul in one hospital and preventing women from going to their nearest hospital. A similar proposal was under consideration in Kandahar. Already female health personnel were not able to make home visits. The implications of such policies for children's access to health care were atrocious. Given the tradition of seclusion of women in Afghan society, it is of vital importance that mothers and children can attend health centres near their homes, and that female health personnel can also go to their homes. It was only after considerable effort by the international assistance community that the Taliban reversed their decision to centralise health care for women in Kabul, and gave their permission for women to be admitted once again into Kabul's other hospitals.

Article 18

1. States Parties shall use their best efforts to ensure recognition of the principle that both parents have common responsibilities for the upbringing and development of the child.

These policies prevent women from looking after their own health and that of their children, and ensure that Afghanistan remains near the bottom of the world rankings for maternal and infant mortality. The civic status of female-headed households highlights the way in which women have been confined by custom in a role where they are powerless to take responsibility for their own welfare and that of their children. It is upon the basis of these gender roles entrenched in custom that the Taliban and other parties to the conflict assert their role as the protectors of women.

The main fatalities in war are men aged 15 or more. Many of these are fathers, and it is the custom that the paternal relatives take on the care of any surviving children. This cultural practice has been reinforced in Taliban edicts that have proscribed the employment of female staff. 
Assistance to widows should be done through their blood relatives without employment of female surveyors. (Annex 1 for all International and National Agencies from the General Department for the Preservation of Virtue and Prevention of Vice, June 1997)

A mother's subordinate position to paternal male relatives can create disadvantage for the child. A child may find itself living in a household where the male relative does not have its best interests at heart.

I used to live with my parents in the same house with my paternal uncle and aunt. My aunt and mother fought and my uncle used to beat my mother. Even when we moved to another house my uncle used to come and argue with us. My father was killed while on duty at a military checkpoint. My seven brothers and sisters and I are still living with our mother but are dependent on my uncle. (Girl, aged 9, Kabul)

Both children and widowed mothers agreed on the importance of keeping families together. When asked what kind of life he would like for his own children, one apprentice-boy working in a tinsmith's workshop in Jalalabad said that he did not want his children to be separated from their family. His own father was dead and he was the eldest of five children under eleven.

Another boy's mother was determined not to remarry, fearful that she would not be able to keep her children with her. Her eleven-year-old son had been injured by a mine and she had four daughters. She was fortunate in that she had paid employment at a hospital in Kabul.

\section{Children and institutions}

The majority of Afghan children who are in 'orphanages' have a surviving mother. No interviews were held with mothers of children who were already in institutions, but interviews with children echoed the apprentice-boy's preference for the family remaining together. Institutions for children, or marastoon, were visited in Kabul, Herat, Kandahar and Mazar. The situation of the Argandob institution in Kandahar province was a little different because, unlike the other institutions which were government run, it had been founded as a madresseh, a religious school which also took in boarders. The Argandob institution was receiving support from the World Food Programme (WFP). Only in Kabul were girls resident. It would be interesting to investigate further what happens to the sisters of resident boy 'orphans'.

The standard of care varied between the different institutions. However, it was striking that in none of them were the children engaged in activities that they described as work. Unlike children still living with their families, who had responsibilities for the care of younger siblings or domestic or agricultural tasks, the children in the marastoon had no responsibilities beyond keeping their dormitories tidy. In Herat, children had been allocated garden plots to tend on the initiative of UNICEF. In Mazar and Herat they had the opportunity to attend the mainstream school as well as classes within the marastoon. In Kabul there were no such opportunities. The higher the standard of care, the more attention seemed to be paid to which children were admitted. In Herat and Mazar-i-Sharif, where the staff took a personal interest in each individual child, there was a higher incidence of children with neither father nor mother. In Kabul the admission criteria appeared more lax and fewer children had lost both parents. The histories behind the children in the marastoon reveal how children become separated from their families and some of the challenges faced by children living in institutions.

After the death of its parents a child may be put in the care of an elderly relative, and thus it may experience the loss of its prime caregiver twice over. 
My mother died when I was six months old. My father left for Iran because of the fighting and from the age of six my grandfather took me in. I lost my leg when a mine exploded and soon after my father was killed in Iran by an electrical accident. My grandfather continued to look after me until his death, when he said none of my other relatives wanted me. Through the help of the international agency SERVE I was found a place in the marastoon.

(Boy, aged 15, Balkh province)

The boy may lose his property rights.

My father had four wives. My mother died as well as two others, and the surviving wife was not kind to me. She asked me to work in the cold and did not allow me to sit by the wood stove.

When my father became sick, I came with him to Mazar where we stayed with my paternal uncle and that is where my father died. My sister stayed on with the uncle, two other children continued to live with their stepmother, and I came to the marastoon. My uncle takes the production of the land that I should have inherited from my father.

(Boy, aged 10, Balkh province)

At least in the marastoon the children found companionship with each other. They swapped stories of their misfortune, and older boys described their peers as brothers.

Only in Kabul were there girls in residence. Three of the six girls interviewed had neither parent, and the other three had only their mother. They lived in near squalor and were subject to the strict surveillance of the Taliban administration: no lessons had been held in the period September 1996-May 1997. The girls found some entertainment through games with each other and a female caregiver on duty in the evening told them stories. This was also the person they talked to if they had a problem. Those children whose mothers were still alive were in contact with them.

The researchers found very few unaccompanied children separated from both parents who were not being cared for by an adult who, by law or custom, was responsible to do so. Where family were non-existent, another benevolent adult had sometimes stepped in. In a carpet shop in Herat the researchers found three brothers stranded far from their native home in Bamyan and being cared for by the shop-owner. The shop-owner had paid the expenses of their father's medical treatment and funeral, and included the three brothers in all family events.

Our family were agricultural labourers in Bamyan. When there were floods our mother tried to save our possessions from the house, but she became sick. We were unable to get medicine for her and she died in Bamyan. After mortgaging our land we went via Mazar and Qala ye Naw to Herat. Our father worked in the city as a barrow-pusher, he too became sick. Our oldest brother, who was working in a brick factory came into the city and took him to the doctor, but it was too late, he died before he was X-rayed. (Brothers, aged 9,13 and 17, Herat city)

All three brothers were suffering from open sores from the bite of the sandfly leishmaniasis, and one had suffered injuries from an overturned oil-lamp. The younger two children hardly talked. They said that they felt themselves to be alone in the world.

Greater, perhaps, than the poverty of hunger is the poverty of being totally alone. 


\section{Children and disability}

Article 23

1. States Parties recognise that a mentally or physically disabled child should enjoy a full and decent life, in conditions which ensure dignity, promote self reliance and facilitate the child's active participation in the community.

It was part of the Soviet tradition to medicalise disability, and to treat children with disabilities within specialised institutions. The withdrawal of the Soviet occupiers and the ensuring war have acted both as a brake on the development of state-run institutions and as an incentive to humanitarian agencies to set up independent institutions. At the same time some humanitarian agencies, notably UN Comprehensive Disabled Afghans' Programme (UNCDAP), have been pursuing another community based model of social care; experience from other war-torn areas shows how the disruption of war can offer opportunities for creative experiments in integration. ${ }^{13}$ It was of interest to the researchers to find out what were indigenous understandings of disability, how far the Soviet tradition had had an impact, and under what conditions children with disabilities were now growing up. Since a significant and visible minority of people with disabilities have been disabled through the war, it was also of interest to know how far the cause of the disability determined social attitudes and the child's living conditions.

Many of the children interviewed were introduced to the researchers because they were participating in an established programme, and could be expected to be benefiting from their participation. Thus there is a particular bias in these findings. This bias can, however, only in part explain the overall positive impression of inclusion which extended to those children with disabilities that did not have contact with an established programme. While the child with a disability, whether sensory, motor or mental, might still feel isolated, no child that we met appeared to be rejected. Instead there was much evidence of empathy from family members.

The family of one teenage girl with a hearing disability is such a case. The girl lost her hearing in a rocket explosion when she was two years old. When her family moved from Kabul to Jalalabad in early 1997 her father learned of the work of SERVE hearing impairment project. SERVE was not able to employ female teachers and girls were not allowed to come to the centre due to restrictions placed by the authorities. Undaunted, her father enrolled himself in the course to learn sign language, and taught his daughter at home. Now aged 13 she was able to express herself more fluently than ever before and her father could help her bridge her isolation from the hearing world.

The words quoted below illustrate the difficulties parents face, especially when there are few practical steps they can take to improve their child's situation. These words were spoken to members of the Save the Children Federation, Inc. family visiting team by the mother of a fourteen-year-old boy who had lost both of his legs above the knee from a landmine accident three years before. They are quoted here because they poignantly illustrate the need to consider not only the child with the disability, but also the caregiver.

I am cheerful on the outside, for my son's sake. But on the inside I am finding all this too difficult to bear. When my son is depressed and lying on the floor, I will sometimes pick up a pillow and lie down next to him to feel what he is feeling with him. I try to be cheerful so he doesn't feel guilty for my grief. Only God knows my pain, only God... (Mother, Kabul)

Children themselves may become caregivers for siblings. This was the case with the ten-year-old girl who was staying in the orthopaedic ward of Kandahar hospital where her younger sister was being treated after falling fallen from a balcony. The ten-year-old and six-year-old shared the hospital bed. 
A number of children were growing up with responsibilities for adults suffering from mental illness.

My father has lost his mind. Relatives are looking after him, but if he wanders off we all help look for him. I regularly take him clean clothes. (Girl, aged 14, Balkh province)

My brother became frightened in the dark. He was speechless, and then began to cry. We took him from shrine to shrine to try and heal him. After a while he felt better and he joined the local military unit. Each night he would come home, and be afraid of people that none of the rest of us could see. My father is away at the moment, and my brother has got hold of a big knife with which he threatens anyone who makes him angry. None of us can get the knife from him. (Boy, aged 15, Balkh province)

Responsibilities within the family are passed from one generation to the next. Some children were growing up knowing that they would become the main carer for a sibling with a disability after their parents grew infirm. The parents of one boy, who was born with cerebal palsy, and the parents of another boy, who had a mental disability and hearing problem since falling into a well at the age of two, were asked who would care for their child when they were elderly or had died. They replied with apparent complete confidence that the child's brother would grow up to take over this duty.

There are other consequences for children if there is someone with a disability in the household. Traditionally if the father died and his sons had not yet attained the age of majority, his brother would take charge of his property. In discussion with the Kuchi the brutal conclusion was reached that children might be better off financially if their father died outright, because then their guardian would have to maintain their property intact. If the father were disabled, he would have to pay his brother for the service of looking after his property, and thus diminish his children's inheritance.

Of the children interviewed 43 had a disability and 28 of these were mobility disabilities. The disabilities were attributed to war (17), disease (12), birth complications (9), and accidents (5). The sampling was not randomised and so these numbers do not reflect distribution across Afghan society, but give an indication of the basis for these research conclusions. When comparing the circumstances of children who had been disabled by war with the other disabled children, it was noticeable that children disabled by war had often suffered other multiple negative consequences of war.

Examples of these contrasting circumstances were found in AABRAR, a Jalalabad organisation which trains people with disabilities to ride bicycles. Within the group of trainees interviewed were boys who had suffered from polio and two boys injured by a rocket and a mine. One interviewee was seven years old and had lost his left leg in a rocket attack. The same attack had killed his father and two other members of his family. In contrast, another eleven-year-old boy, who suffered from polio, had all his family alive.

\section{Children and ethnic difference}

Article 30

In those States in which ethnic, religious or linguistic minorities or persons of indigenous origin exist, a child belonging to such a minority or who is indigenous shall not be denied the right in community with other members of his or her group, to enjoy his or her own culture, to profess and practise his or her own religion, or to use his or her own language. 
Gender and disability are individual characteristics. Ethnicity is the characteristic not only of the individual child but also the group with which the child lives. Women and girls have acted as an interest group, for example women in Herat demonstrated to protest the closure of the public baths to women in Herat, and disabled peoples organisations are just beginning to establish themselves across the country. However, ethnic groups have a much longer and more visible tradition of political organisation and militancy. This makes the child of an ethnic group peculiarly vulnerable. The child's group may be championed by a military commander with a personal interest in perpetuating the war. Cross border minorities may find themselves made the vehicle for the ambitions of the neighbouring state.

In the very few instances where the research team was not able to have access to children the reasons were due to the mistrust engendered by poor relations between ethnic groups. In Herat, the researchers were advised against visiting homes in the Shi' a quarter because there had been a spate of arrests of leading members of the Shi'a community in the preceding days, and any interviews by outsiders might put other members of the community at risk. In Andkhoy, an Uzbek enclave in Jowzjan province, the researchers were limited in their access because of the heightened suspicion of strangers as the Taliban made significant advances in the northern zone.

The rumours of the worst atrocities associated with the war invariably included reference to the ethnicity of the perpetrator, as though only people of another kind could perpetrate such inhumane actions.

Children are repeatedly exposed to the following kind of stories where the two sides were clearly identified in ethnic terms, and one side was clearly blamed for all the ills that ensued:

When the bombardment by those heathen Uzbeks started we left on foot with only the bags we could carry. Three months afterwards I was still frightened when a plane went overhead. When we reached the river, the waters were so high some people were swept away. We wanted to bring our animals with us, but they could not cross the river. We were trapped between the mountains: on one side were the Taliban and on the other side the Uzbeks. (Mother, Rawza Bagh camp, Enjeel district, Herat province)

The population of Badghis that were put to flight were Pashtu speakers and seen by the Uzbek forces as possible hosts for the invading Taliban.

In Maryam School in the Said Abad district of Mazar, which is largely populated by Hazara, when asked why people were fighting, one child said that the Taliban wanted to get all Afghanistan for the Pashtun. In Kamaz camp, IDP children from Kabul saw the war as a fight against the Hazara.

Afghanistan has a long history of population exchanges, but the country's recent conflict has produced particularly large population displacements. Afghans will bridle at the suggestion that the current conflict is an ethnic conflict, and the majority of children's interpretations show a different understanding. The majority of children interviewed understood the war as a fight between leaders who wanted power and money, and who recruited fighters either by force or for payment.

The armed conflict and the displacement that it has engendered has provided opportunities for many encounters between children of different groups. These confrontations with other cultures may begin on an uncertain footing, for example the parents of children from the Morghab farms of Badghis province who moved to Herat were wary that if they let their children go to school they would become like the Heratis. They saw the Heratis as having very different attitudes and ways. 
When asked what message they had for other children in Afghanistan, the children in Rowza Bagh camp asked the researchers to let other children know the conditions they were living in. "Find out more about Afghanistan" was one of the repeated messages that children sent. Other messages made no reference to enemies, but were addressed by children to other children regardless of their ethnicity:

\section{Do not fight!}

Do not touch UXOs!

Beware of mines!

Help parents, and care for younger brothers and sisters!

Don't be jobless!

Have enough food and good health!

As Graça Machel concluded: "in a world of diversity and disparity, children are a unifying force capable of bringing people to common ethical grounds. Children's needs and aspirations cut across all ideologies and cultures." 14

\section{Protection from harassment and the forced participation in military units}

From the above examination of groups of children requiring protection it can be seen that certain children have stronger links to their family and to the wider society than others. The civic status of women means that children in female-headed households may find their mother is unable to act as a strong advocate on their behalf, and may even have to abandon them. Disability also places additional strains upon the whole family. Lastly, the child's ethnicity may make it a target.

Gender, disability and ethnicity are just some of the aspects which construct personal identity. A better understanding of how these factors influence the position of the child within society, and affect the strength of the group to which the child belongs, would help in identifying the most vulnerable members of society.

If we turn to the engine of war, and examine the pattern of harassment of households by military commanders, and the forced participation of children and adolescents in military units, there are indications that it is these most vulnerable members of society who are being forcibly recruited. The northern area is home to many diverse groups. This interviewee is Hazara.

My brother went to Pakistan in 1984, because the leader of the Harakat party wanted him to fight. My brother didn't want to fight. The Harakat party found him in Pakistan and again put pressure on him to fight against the Russians. Instead he worked in a bakery and went to school. All this time my mother had stayed in Hazarajat. She wanted to see her son and so travelled to Pakistan in 1989. Together they were travelling back to Hazarajat when they were attacked by thieves. When my mother saw the thieves tie her son's hands behind his back her heart failed. My brother had to carry her dead body to Hazarajat.

(Girl, aged 18, Said Abad district, Mazar-i-Sharif)

Families in the Dehdadi district of Balkh province described how they had taken the decision to move from one village to another when they were harassed by the local commander. The head of the shura (district council) was alleged to be acting in co-operation with the commanders by providing lists of households with young men who would not be able to put up any resistance. Young men were taking refuge in the city of Mazar-i-Sharif, or further afield, to avoid recruitment; however this then left their families prey to commanders' demands for contributions such as cash or food for troops. 
Mothers in the area said they felt powerless as long as they were facing armed men, however they also acknowledged that all the men carrying arms were known to them and were husbands, fathers, or cousins of members of the same community. If this were the case, there would appear to be scope for women to influence their menfolk and dissuade them from recruiting young boys. At the same time women would have to develop networks to include boys living in femaleheaded households. Such an idealistic, local approach does have examples of success in some areas where the muy safid (white-bearded elders) of the village have reached agreements with the local commander to regulate conscription. ${ }^{15}$ The resulting agreements were close to the spirit of the Convention on the Rights of the Child.

\section{Making a reality of children's rights to protection}

The researchers found very few children who were totally alone. The poverty of human relationships is as significant for the wellbeing of the child as the poverty that is measured by food or housing. In developing programmes to strengthen the child's right to protection, it is with the group to which that child is already linked that the agencies should work. A better understanding is required of the ways in which the child is delinked from the group. In the case of children who end up in institutions, the numbers are so small it ought to be possible to reverse the trend, and to trace families and re-establish links for some of the children. The institutions themselves should be converted to serve another function so that they do not act as magnets for 'orphans'. In the case of children who are forcibly recruited to military units numbers are far greater, and the reversal of the trend requires painstaking work to strengthen the status of these children's families within the wider group.

The researchers found no reliable evidence of sexual abuse. Given the nature of the study, a series of one-off encounters with groups of children, this is not surprising. A different kind of study would be required to highlight such a sensitive problem.

An underlying theme within this chapter has been the danger that the protection offered to a child could become somewhat smothering. The families of disadvantaged children, and in particular their mothers, need to be empowered so that they themselves can define their interests and then make accountable those who they select to forward those interests.

Another theme has been the confinement of disadvantaged groups to limited areas of space. Women and girls have been denied access to public space. Boys in institutions have less freedom to come and go than boys growing up in their own families. People with disabilities are also restricted in their movement. Ethnic groups become ghettoised, and choose to live together for fear of the outsider. The extension of the public space in which children and their families can move with confidence would be a measure of the extent to which their right to protection is upheld.

One example of an indigenous tradition of community responsibility for the wellbeing of its disadvantaged members and civic structures to protect and empower them, was found in a village in Enjeel district, Herat province. The village had a benevolent fund which could be used to cover medicine and funeral expenses. The arbab (village leader) held the money collected from the traditional Muslim donations of zakat (alms) and oshr (tithe). He then lent the money to a carpet seller, and profits from the sales of carpets went to the benevolent fund. Recently the representatives of the UN Comprehensive Disabled Afghan Programme (CDAP) had worked with the villagers to address the problems of those among them who had disabilities. A decision was taken that in future people with disabilities should be helped from the fund, and that where possible they should be helped to set up their own business initiatives. Already one disabled person had been able to set up a shop with assistance from the fund. 
Those in control of the fund were from the village and claimed to know who was most needy in the village. However, more investigation is needed of the traditional means of redistributing wealth within communities and the prejudices and priorities which control distribution of wealth not only within the village but also within the household.

In Balkh and Jowzjan provinces Save the Children Federation, Inc. has developed a Group Guaranteed Lending and Savings Scheme (GGLS) where the participants are women. Gradually the GGLS is proving that economic power can encourage a shift in relations within the household, and also could open public space to women. Initially the programme was home-based, now the women were walking to the office to make applications for loans, pay back and receive loans, and hold group meetings. In discussion the women explained how far afield they travel to market their produce. Some went as far as Ghazni to seek out better prices for their carpets. 


\section{DEVELOPMENT}

Article 39

States Parties shall take all appropriate measure to promote physical and psychological recovery and social reintegration of a child victim of: ... armed conflicts. Such recovery and reintegration shall take place in an environment which fosters the health, self-respect and dignity of the child.

This chapter focuses on how children in Afghanistan learn, and how this development is affected by the war. Already the challenges to parents of providing the necessary security, shelter and economic means for their children's physical survival have been discussed. Attention has also been drawn to the discrimination that may jeopardise the child's physical health, and place children and their families in insecurity or at an economic disadvantage. It is at this physical vulnerability that assistance has been directed in the past. Assistance that will promote the child's mental and emotional development has been less widespread and is also more contentious.

After the explosion of interest in the effects of 'trauma' in the aftermath of NGO interventions in Rwanda and Bosnia its relevance to non-western societies is increasingly being questioned. Instead the importance of attention to broader social, emotional, economic and developmental needs is being reaffirmed. Throughout this research emphasis has been on the child as part of a social world, in which problems and joys are intimately associated with those of other childrenwhether siblings, playmates, classmates or workmates - and adults, the most important of whom are parents. It is one of the great strengths of Afghan society that the vast majority of its children are still enlaced in strong social networks. When the child is in extreme distress it is not alone but surrounded by this social world. There is a danger that interventions which encourage an individualised approach and build an institutional capacity based on this approach will weaken these networks. Gradually lessons are being learned from other war-torn societies, which point the way to a community based approach.

"People can be helped by letting the community get back together again, helping people rebuild their houses, and getting the markets and trading going again - the things that make lives meaningful. These are the important things that can allow people to leave behind the past and make life meaningful again. The problem is that concepts and techniques, structures and organisations which are alien to the tradition of those people can interfere with this process of moving forward."16

"The core issue is the role of a social world, invariably targeted in war and yet embodying the capacity of survivor populations to manage their suffering, adapt and recover: this means a collective, not individualised, focus."17

\section{The home}

Children's first and most important place of learning is the home. Within the home parents, with help from siblings, grandparents and others, are potential carers and role models. For this reason the research team held discussions with parents, asking them about their observations of children's behaviour and what problems they faced in rearing their children. Both mothers and fathers were keenly aware that the war affected not only their capacity to provide for the material needs of their children, but also for their mental and emotional needs. They recognised the spiritual effects of the war - bereavement, traumas and hatred, feelings of revenge - and they were deeply concerned as to the problems these effects could cause in the next generation. 
It was clear that parents had their own pain as well as being witness to that of their children. Their reactions depended on the intensity of their experiences and their closeness in time. In Rawza Bagh camp, established in December 1996, mothers were still too preoccupied with their own experiences to talk about observed changes in their children. First they wanted to narrate what they had left behind: houses, farms, shops, orchards and worst of all:

Several children were lost on the way: there was one seven-year-old who could not keep up. Another mother tied her child to a donkey, and after a while she heard no sound and realised the child had fallen off and was no longer there.

(Mothers, Rawza Bagh camp, Enjeel district, Herat province)

Only after telling of their own painful experiences were parents able to describe their children's memories.

Eight months after the terrible journey, our children are still frightened. My ten-year-old wakes and says that the Uzbeks are coming. He clings to me and won't stay alone in the house. (Mother, Rawza Bagh camp, Enjeel district, Herat)

In the neighbouring CTC camp, where IDPs from Kabul had been living for five years, they were still haunted by lingering memories. A father described how a rocket had hit his house, burying two children alive. He had escaped with his wife and two other children to Herat, but his wife was still mentally disturbed. The researchers asked people how they tried to find peace of mind under such circumstances. Women in the camp said that they visited shrines, dispelled bad dreams by telling them to water, burned incense and read sura from the Quran. Some would seek assistance from a mullah or an older woman with religious wisdom.

The researchers visited women in Enjeel district, Herat province whose worst experiences of the war had been during the time of the mujahidin fighting against the Russians ten years earlier. One woman reflected on why she hit her children. Her husband had been killed in the war, and she felt that, if her husband were there to share the responsibility of their upbringing, or if there was a school near by so that the children were out of the house, she would have more patience with her children. She regretted her actions and knew the children were not to blame.

Women had also observed their children beating each other. One boy, who was four when his father was killed, repeatedly beat his sister. Again the mother attributed his behaviour to his direct experience of the war. Another woman told of a boy aged 12 who was frightened to return to his home because he had seen his two brothers killed there.

At the same time these women were also aware of the indirect effects of the war upon their lives. They cited economic worries as their main burden. The priority given by both mothers and fathers to economic worries confirms the emphasis placed on the family unit and the creation of productive livelihoods in the "Draft strategic framework for international assistance in Afghanistan" prepared by the UN Inter-Agency Mission to Islamabad and Afghanistan in October 1997. ${ }^{18}$

Midwives in Kabul had given the same message: they made an association between children with low weights at birth, and the economic stress suffered by their mothers. They quoted the following Dari proverb:

Richness makes you ready to dance From poverty comes frailty 
The greatest problem facing fathers is that they are absentee parents: forced to seek work far from their families or detained at the front or in prison. Even fathers who were with their families identified the difficulty of finding enough time to spend with their children. Urban families in Herat and Kabul had enjoyed two wages from both husband and wife; now only the husband could go out to work and he therefore had to work longer hours in order to maintain the level of the family's income. In Mazar-i-Sharif women were not barred from work at the time of research, but parents explained that they were both obliged to work longer and longer hours because of inflation and falling levels of income.

Article 31

1. States Parties recognise the right of the child to rest and leisure, to engage in play and recreational activities appropriate to the age of the child and to participate freely in cultural life and the arts.

Mothers said that if they were happy they would spend more time caressing their children, singing and joking, and helping the older children to read and make things. Urban parents reminisced about the way in which on Fridays and Saturdays they used to go for picnics, receive guests and visit other families. They were able to take their young children to green places and to other homes. Now they are trapped in their own homes.

One activity that does persist within many homes is storytelling. The storyteller's imagination can transcend the pain engendered by war and give solace. Stories were told by grandparents and older siblings as well as by parents. These stories were not wholly preoccupied with the armed conflict; some were traditional stories of the prophets, kings and queens, beggars and students whereas others were popular tales such as the jokes of Mullah Nasreddin. Many younger children listened to fairy stories with heroic female animal characters and strong happy endings. Storytelling time was also filled with the family history. Here adults might pass on information about members of the family who had taken part in armed conflict, but the histories were as likely to be a narration of a journey or the building of a new house.

One ten-year-old boy said that his mother told him stories to relieve the pain of his injuries. He had lost a leg, a part of his finger and damaged his intestines. He and three of his brothers were injured when a mine exploded in the backroom of their Kabul home.

Storytelling was not confined to the family. In Mazar-i-Sharif the boys in the marastoon told each other stories and jokes until late at night, and boys aged 8-10 in Kamaz camp told each other tales of the adventures they had when working around the Rawza shrine. This latter group said that adults did not have time to tell them stories, so they made up their own.

A fifth of the children interviewed were never told stories. This was one indication for the research team of a home in which there were very limited resources for the child's mental and emotional development.

Not all children had the free time for games however the majority of children were able to quote games they enjoyed now or had enjoyed when younger. The most often quoted games were traditional. Young boys played ursai, which involved trying to knock down one's opponent while all the time hopping on one leg, and marbles. Young girls made dolls out of scraps of cloth, and played five stones, hopscotch and rhyming games. Few children had access to toys. Sometimes IDP children remembered that these were among the possessions they had left behind when displaced. In Andkhoy, Jowzjan province, where there had been less disruption, older children said that they had passed on their toys to younger siblings 
Boys continued playing to an older age than girls. In their teenage years they would still have free time to go swimming in the canal, or to play football. If they were fortunate enough to have a ball it usually belonged to the group. Girls soon began using their free time for creative tasks such as embroidery and sewing. These tasks could often be done while sitting in a group and could be accompanied by storytelling.

For security, ideological and economic reasons the opportunities for children to enjoy recreational activities and explore their environment were being curtailed. In many residential areas of Kabul the hazard of mines deterred children from playing outside. As well as issuing edicts banning the playing of music, the flying of kites and the playing of chess, the Taliban have issued edicts forbidding girls and women from going on picnics.

\section{I have not been on a picnic since 1995 and the time of Ismail Khan. (Girl, aged 9, Gozara district, Herat province)}

In the north, television was an important source of recreation. In other areas, the authorities had banned television, and only a few families with the money and the security protection to risk setting up a satellite TV could watch. Hindi films were especially popular and boys and girls, men and women gathered in front of the television set.

Some children found most of their time was taken up by work. This was especially true among poorer families in both rural and urban areas.

\section{In between going to school at the mosque I look after the animals and help my father. I carry to the fields food and any tools he may need. Because we are farmers we have no free time.} (Girl, aged 10, Enjeel district, Herat province)

Although the stories they narrated demonstrated that some children were still free to roam in their imagination, children, both boys and girls, described themselves as being physically trapped inside the home. Those children who were going out of the home were often forced to do so by economic necessity, and were spending their days working in the streets or fields.

\section{The mosque and school}

Article 28

1. States Parties recognise the right of the child to education, and with a view to achieving this right progressively and on the basis of equal opportunity, they shall, in particular:

a) Make primary education compulsory and available free to all;

b) Encourage the development of different forms of secondary education, including general and vocational education, make them available and accessible to every child, and take appropriate measure such as the introduction of free education and offering financial assistance in case of need;

c) Make higher education accessible to all on the basis of capacity by every appropriate means;

d) Make educational and vocational information and guidance available and accessible to all children;

e) Take measure to encourage regular attendance at schools and the reduction of drop-out rates.

Article 29

1. States Parties agree that the education of the child shall be directed to:

a) The development of the child's personality, talents, and mental and physical abilities to their fullest potential;

b) The development of respect for human rights and fundamental freedoms, and for the principles enshrined in the Charter of the United Nations; 
The development of respect for the child's parents, his or her own cultural identity, language and values, for the national values of the country in which the child is living, the country from which he or she may originate, and for civilisations different from his or her own; The preparation of the child for responsible life in a free society, in the spirit of understanding, peace, tolerance, equality of sexes, and friendship among all peoples, ethnic, national and religious groups and persons of indigenous origin;

One acceptable location to which both boys and girls can go is the mosque. Lessons are also held for boys in the religious schools or madresseh. Girls and boys may study the Quran in the home of a male or female teacher. Girls attend until about the age of ten, boys for longer. In these centres of learning, children meet with their peers, and have the attention of an adult who is not their normal caregiver. Academic development varies: they often acquire the basics of literacy. In discussion with adults who had gained formal educational qualifications they all said that they had first learned to read and write through religious studies of the sipara (thirty Arabic verses of the Quran) that were still being taught by religious teachers. These Afghans, who progressed to formal secondary and university education, are proof that the mosque, the madresseh and home schools can act as a bridge to formal academic learning. These religious study classes are paid for by their parents either when the child attends the class or as part of the parents regular contribution to the mullah, exacted from all members of the community. They appeared to be a useful example of the ability of the community to contribute financially to children's education, and to have as strong a foothold in rural areas as urban areas.

UNICEF has for some time been aware of these traditional private initiatives and noted that little information has been collected from them. ${ }^{19}$ In Mazar-i-Sharif the government education department had been distributing primary level textbooks for Dari language and mathematics to the mosque schools. It would be interesting to know more about the nature of the curriculum and ways in which it could be extended to meet the children's developmental needs. In discussion with mullahs and religious teachers the researchers found a willingness to extend and improve the curriculum they could offer.

I have started a school for the children here. My own training is as a mullah, and I only know how to teach religious studies. I know that these children cannot all grow up to be mullahs, if they had stayed in Badghis they would be learning how to farm, but I feel it is better to teach them something than nothing. If I knew how to teach them something else I would. In the future there will be too many mullahs and no farmers, and then God will have to feed us. (Mullah, Kandahar province)

The Convention on the Rights of the Child argues that, with a view to achieving the right of the child to education progressively, States shall make primary education compulsory and available free to all. The majority of children in Afghanistan never enter state sponsored primary education. The minority who attend primary school begin at the age of 6 or 7 and study for between two and three hours per day for as many years. They are predominantly boys. The primary school is therefore not the place where most of children's learning takes place. One of the reasons for the low support for primary education, both from the remaining state structures and the parents, is that primary education is associated with the policies of the Soviet period. Education became a politically contested area, in which those associated with the modernising Soviet style government and the traditionalists and nationalists battled for young minds. This made primary education an area fraught with difficulties. The Afghan Development Association (ADA) has 
faced opposition to its school building programme in Zabul province, but over time has been able to convince parents of the benefit of primary schooling. In one area parents first destroyed a school, and then three years later petitioned ADA to refurbish it.

The way in which the Taliban have insisted upon their opposition to schools for girls has again politicised the education sector, and underscored its gender inequity. However, the research team found that the Taliban were merely making public the sentiments of many fathers. When we asked girls the reason why they were not in school some said that their fathers had not given permission and would not give permission even if the schools were to reopen. The majority of these girls wanted to go to school. The insistence by the Taliban that girls' schools should remain closed has diverted advocacy efforts from the longer term task of changing the minds of fathers.

There is of course an exceptional minority, and since the imposition of Taliban rule across four fifths of Afghanistan, some parents have taken considerable risks either to open home schools or permit their daughters to attend a home school nearby. In the heart of Kandahar two unmarried sisters who were former government school teachers had their own parents' permission to open their home to give daily classes to thirty girls.

Within the Taliban administration itself there were also found to be supporters of girls' schools. This was the case in a small town in the south-western zone where a home school served seventy girls in a building provided by a member of the Taliban administration, and in Herat where the tent schools in the IDP camps have permission to teach girls. Those who can afford to are also making use of the dwindling educational opportunities available to Afghan girls in Pakistan.

Young children saw school's value as improving their own future.

If we don't study we will become porters.

(Boy, aged 12. Jui Haft district, Jalalabad city, Nangahar province)

In her enthusiasm to go to school, this interviewee had overcome a double disadvantage as a girl with a disability:

My father said that I was too old to go to school, but I insisted. My younger sister was going at the time. Then the school refused me because I was physically too small. Finally I was admitted and studied for two years before the Taliban came.

(Girl, aged 13, Enjeel district, Herat province)

It was striking that those adolescents who were attending secondary school saw the purpose of their education as to contribute to the development not only of themselves but also of their country. In the Faride Balkhi School in Balkh a group of 14-16 year-old girls aspired to be teachers, doctors and engineers in order to serve their country. At the Karte Sulh School in Said Abad district of Mazar-i-Sharif a similarly aged group of boys described their country as underdeveloped, and were committed to rebuilding it. In Herat teenage girls, who had had no access to school since the Taliban take-over, saw themselves as having been denied the opportunity to help their country. A number of older girls were present at the Qul Urdu shrine in Herat for Wednesday prayers, and they had come to pray for the schools to reopen.

Although half the children interviewed during the course of this research were attending schools which offered more than religious studies (this includes government and non-governmental schools, madresseh and home-schools), this is not a fair reflection of educational opportunities in Afghanistan. The numbers are high partly because the research team deliberately sought out girls attending home-schools in each of the Taliban controlled areas. Among those interviewed who 
were not in school, the reason most often cited by girls for non-attendance was lack of permission either from parents or the authorities or both. Setting aside the problem of permission for girls to attend schools, economic problems were the reason most often cited for failure to attend. Even if families could afford to send their children to school, many children in Afghanistan simply do not live within walking distance of a school. Those that do attend complained that the teachers were often absent and that they had no textbooks or other school equipment. Because of the war and displacement many children have had disrupted schooling and were not studying the grade equivalent to their age. All teachers said that children's concentration was poor.

If a wind comes and shakes the tent, or we hear firing, both the teachers and pupils feel frightened. (Teacher, CTC camp, Herat)

My tent is next to the school tent, and I sit outside and listen. I can hear that the pupils do not remember their lessons from one day to the next. The teacher is very patient but with no result. (Father, CTC camp, Herat)

Many working children also had other responsibilities which distracted them from schooling. Teachers described how children put their heads on the desk, heavy with sleep and hunger. The teachers themselves were worried. They too had economic problems: in a school for boys in Balkh the teachers had not received their salary for four months. One possible explanation for a situation where only three female teachers were present was that all the male teachers were heads of households who could not afford to go unpaid.

Despite these shortcomings, children were generally very positive about school. It was the one place that was dedicated to children. There they could meet their peers and have the attention of an adult from outside their family. When asked for a role-model, many children chose a favourite teacher.

If you don't like school, then what are you going to like?

(Boy, aged 12, Qargheyee district, Laghman province)

\section{Apprenticeships}

The third place of learning that the research team identified was the workshop where children and adolescents learned a skill under the supervision of an adult. The majority of the participants in these workshops were boys, but tailoring courses were also being taught for girls. Many girls also learned a skill at home such as carpet-weaving.

The research team became intrigued by the gap between the children's expectations of what work they would do as adults and the realistic options. Some children kept a parallel set of expectations.

If we attend school and study, we can become doctors and teachers, otherwise we will become carpet weavers. (Girls aged 11-13 in private religious studies class, Jowzjan province)

The gap appeared to narrow with age, and with adolescence the childish dreams of being an engineer, a pilot or a doctor had faded, and they were replaced with other hopes. The message from a group of teenage boys working in a metal workshop in Kandahar to other children in Afghanistan was:

Study well, don't be like us and carry the hammer! Be independent and don't be under pressure from other people! 
Apprenticeships appeared to provide many adolescent boys with an income, a mentor, a peer group and meaningful daily routines and purpose. However, hours were long and this was the community's only service targeted to adolescent boys. Some adolescent boys were often making a significant financial contribution to the household but were excluded from decision making. Others prematurely became head of household because of the death of the father. This was the group which appeared to have the most to offer to Afghan society.

\section{Volunteering and participation in military units}

It was adolescent boys who were most likely to volunteer to participate in military units. When the young recruit becomes a fighter of his own free will, then the question must be asked as to why he came to the conclusion that he should fight. What value system does he have, and how did he learn it? Learning takes place from a very early age. Much of the child's sense of right and wrong will have been formed before the child was of school-going age. Even if the child went to school he would spend only two to three hours of each day there. Much criticism has been made of the textbooks developed by the mujahidin with international assistance in which even seemingly politically neutral subjects as arithmetic were taught using examples such as one kalashnikov plus one kalashnikov equals two kalashnikovs. However, school is of less significance than home as a place of learning. In order to educate a generation that will not volunteer to perpetuate the conflict, attitudes need to be formed in the home.

It is by an attack upon the home and members of his family that a boy's strongest feelings for vengeance are going to be aroused, and it is by the example of his father, older brothers, cousins and uncles that he will set most store. Young boys were reported to have left the IDP camps of Rawza Bagh, Enjeel district, Herat in order to fight and revenge lost lands and members of their families in the Morghab.

It was encouraging to find that most of the children interviewed participated in special occasions such as wedding parties, picnics and Eid celebrations, which had not been militarised. It was also encouraging to find that many children were told stories by adults and that the imaginative domain had not been completely filled by war. The formal education sector can only provide secondary support to parents. It can deliver literacy and numeracy, and teach children the social skills required for group work and leadership, but it cannot replace good parenting.

From discussions with children and parents it appears that less value is now being set on fighting. There is disappointment that the struggle against the Russians has degenerated into an intraAfghan war. Very few respondents talked in terms of an identifiable enemy. The exceptions were those groups who perceived that they had been victimised because of their ethnicity or religion.

For those boys living as boarders in the madresseh, the situation was different. Their values were inculcated by their teachers. Armed with an ideology, they appeared better prepared to join the armed forces than those boys who joined because of economic necessity or forced recruitment. This is one group of Afghan boys who may find it easier to interpret and cope with violence and suffering, because they do have a commitment to an active involvement in a political cause.

I volunteered to fight for Islam and went to Kabul with the Taliban. I was there only twenty days, my older brother would not let me stay longer. He has already been injured and his hand is now paralysed. (Boy, aged 17, madresseh student, Kandahar province) 
The BBC Afghan Education Programme has plans to develop more children's programming. This would create a space in radio broadcasting that would not be occupied by news of the war, and it would supplement the storytelling that is already happening in the home.

Only in Mazar-i-Sharif were any initiatives found which targeted adolescents. The NATURE youth group supported by UNCHS (Habitat) is an example of how the energy of adolescents could be channelled. However, priority should be given across the country to more consultation with adolescent girls and boys to identify appropriate activities in which they could be engaged.

All these programmes add to, rather than supplant, the efforts of parents to bring up their children. They instill a much needed sense of security either through the establishment of a safe place or through routine. The pity is that they are so few and far between. 


\section{PARTICIPATION}

Armed conflict is not the monopoly of the recruits, the commanders or the arms suppliers. Everyone else in Afghanistan is involved either as a victim or beneficiary of the conflict. Children have a vital stake in the conflict as members of the generation that will live on to inherit the warravaged country. Already it has been seen how closely children were involved in the day to day work of providing for the household's livelihood. It has also been seen how the war intruded on every aspect of civilian daily life. It was therefore a major question for the researchers to find out how far children had the opportunity to discuss the war and its consequences. This chapter is dedicated to the theme of participation.

\section{Children and information}

\section{Article 13}

1. The child shall have the right to freedom of expression; this right shall include freedom to seek, receive and impart information and ideas of all kinds...

A Kabul parent described a conversation she heard between her three-year-old daughter and a fiveyear-old when there was the sound of a plane going overhead. The three-year-old said they should go down to the basement, the five-year-old said they need not bother because it was a government plane.

There is evidence that children younger than those that were interviewed for this research are already making their own interpretations of events related to the war. Older girls in Qalaat, Zabul province were aware that helicopters were bringing back Taliban casualties from the frontline. All children observe their parents and those adults around them reacting to news of the war.

\section{When her brother or father comes from Kabul our mother always cries because they bring} news of the war. (Girl, aged 10, Balkh province)

Some childen will have been privy to information directly connected with the war.

\section{When Haji Qadir was the commander we had a gun in the house.} (Boy, aged 12, Surkhud district, Nangahar province)

When asked whether any adults discussed the war with them, three fifths of the children said yes. Usually this was a male member of the family. Certainly the children discussed the war among themselves. Younger boys, but not girls, were observed incorporating war experiences in their play. Older boys passed on information about the war to both their younger brothers and sisters. Within the marastoon it was also the older boys who were the children's main sources of information about the war.

The extent to which children were told about deaths of close relatives and death in general varied from family to family. Some parents claimed that it was not usual to talk about death with young children, and that they would instead be told that the deceased was on a long journey to Iran or Pakistan and would come back one day. Others deliberately talked with their children about the dead person and how the death had happened. In a group of Kuchi girls aged 8-11 a mine had killed one girl's father just three days before the interview. Another interviewee said that her mother had discussed with her the death of another interviewee's father. The group then explained that it was usual for the widow to stay in her tent for the mourning period. Children were often observers at rites of mourning, which were structured around the gender roles. 
Children had experience of death not only through war. Many children mentioned grandparents who had died from natural causes and younger relatives who had died in traffic accidents, falling from balconies or into wells. When asked to say how many brothers and sisters they had, they would mention those who were no longer alive. These deaths were part of their family histories, and had been shared with them.

\section{Children and the media}

Article 17

States Parties recognise the important function performed by the mass media and shall ensure that the child has access to information and material from a diversity of national and international sources, especially those aimed at the promotion of his or her social, spiritual and moral wellbeing and physical and mental health.

Radio ownership was widespread. Only the very poor, and particularly the recently displaced, did not have a working radio. However, usually it was the adults who listened. Some older children followed the news themselves, and a very few saw the radio as a source of information about the wider world.

\section{I have heard from the BBC that men went to the moon. Is this true? (Boy, aged 15, Argandob district, Kandahar province)}

A few children listened to children's programmes broadcast from Iran and Pakistan. Perhaps there would be more young listeners if there were children's programmes within the BBC Afghan service.

\section{Identification with Afghanistan and perceptions of the war}

On the strength of this information the research team wondered how children interpreted the world around them. The team were especially interested to understand children's understanding of their own place in the world, and their perception of the war. Already this report has shown the richness of Afghan children's human relationships. How far did this extend? Did it extend beyond the family and immediate circles of neighbours and the community in which the child played studied or worked? Children from ethnic minority groups were seen to identify themselves with that group, often because they had been the victims of attack, but did any children identify with Afghanistan?

Those children who have the clearest perception of their country are those who have had to cross the border as refugees. A six-year-old sitting next to the consultant on the public bus from Kabul to Jalalabad struck up conversation by asking: "Which do you prefer Pakistan or Afghanistan?" She was clear that life in Afghanistan was good whereas in Pakistan it was bad. The majority of the families living in Rawashan, Herat province had returned from Iran. One boy had attended school to grade 6 in Iran but after that, because he was Afghan, had not been able to continue his schooling despite petitioning several departments. On his return to Afghanistan he had been able to get admission immediately. The point he was making was not about the quality or availability of the education, but the discrimination based on nationality that governed admission.

Both in Pakistan and Iran refugees often enjoyed a higher standard of living. These children from Rawashan fled their village when all except the house belonging to the arbab (village leader) was destroyed. Over the last three years they had returned. 
Life in Iran was better than here. We had good food, running water, electricity, transportation, a hospital to hand, no dust, good weather. We left our village when we were very small and when we came back here we thought that our village would be like Iran, but when we arrived we learned differently. I saw a cow here for the first time, and now I spend my time looking after animals. (Boys aged 11-17, Enjeel district, Herat province)

When in Iran we prayed to God to help us set Afghanistan free. We listened to the radio, and when we heard bad news about the village we felt sad. Most of the time there was very little news. Life was better in Iran, but here we feel more free.

(Girls aged 14-17, Enjeel district, Herat province)

Teenagers would remember the fight against the Russians. Younger children have had to find other explanations for the more recent fighting. In response to the question, "Why do you think people are fighting?", children gave three categories of response. The overwhelming response was that leaders were fighting for power, and that recruits were coerced to join them. The second category of response was that leaders were fighting for money, and that recruits were joining them because they too needed money. The third category of response was that people were fighting for an idea, for Afghanistan, for Islam, and that recruits were joining them voluntarily.

They are fighting for power and when they lose they escape by plane and poor people are killed and wounded. (Boys aged 13-17, Mazar-i-Sharif, Balkh province)

This is the record of a discussion which took place in a workshop in Jalalabad between two boys aged 14 and 15 , as to whether groups could have mixed motives.

- The Taliban are fighting to establish an Islamic government.

- In fact we don't know what they are fighting for, it may be for their private benefit.

- Do you think this is true of the Taliban as well?

- Yes, all of them.

\section{Children as future parents}

When asked to close their eyes and imagine what kind of life they would like to give their own children, the children interviewed gave overwhelming priority to education. By education they meant they wanted their own children to learn, to read and write and to have a skill. They attached value to the ability of their children to earn their daily bread and to be able to help rebuild their country. This response was given more frequently than the hope that their children would grow up in peace and security.

Next among their responses were wishes for a good economic situation, food, clean clothes and shoes. A high proportion of displaced children mentioned the need to give their own children a home.

Some children also wanted to provide their children with a playground and toys.

A smaller group of responses wished that their children would be happy, become nice people, and help their parents and their neighbours.

Individual children expressed the wish for their own children not to be separated from their family, and hoped that they as parents would be in a good mood and talk with their children. 


\section{Making a reality of children's rights to participation}

Childhood is a social construction, and the age at which children achieve majority and take part in decision-making depends upon each society's norms. However, all children below the age of majority need to be prepared to take an active and informed part in decision-making. Children need information appropriate to their age and ability. More can be done to make sure that children do have access to information.

Ensuring the inclusion of all children, whatever their abilities, in this information exchange can be a laborious and specialist task that needs dedicated specialists. Through its hearing impairment project, SERVE is making it possible for children, isolated from the social world by deafness, to communicate. SERVE has developed an Afghan sign language and is also using this sign language to teach literacy. At the centre the children begin each day by using the sign language to tell the other members of the group about an event that has happened to them. Outreach workers visit the children in their homes and work with the families to help them help their child. Adolescents are encouraged to learn skills and join apprenticeship schemes. During their visit to Jalalabad the research team was impressed by the skill and patience of the locally employed outreach workers. The challenge for such a programme is to multiply the number of trained staff so that they can provide similar opportunities for hearing impaired children in all parts of Afghanistan.

Most children do not have to get over the hurdle of deafness before gaining access to information. The radio can be an important source of information about the outside world. Better still it could be used as a medium for children to express their views and inform each other of initiatives they have taken within their community. In July children with disabilities from all over Afghanistan visited Kabul to participate in a sports tournament. All credit should go to the agencies who took up the logistical challenge of transporting and accommodating the children. One participant who the research team met after his return to Jalalabad said that what impressed him most was not the opportunity to participate in the bicycle race, but the chance to exchange views with children from other parts of Afghanistan. Radio debates between children could be arranged on local and national networks with much greater ease than this sports tournament.

Many children face the hurdle of learning to read. This raises the further question of what materials are available for the literate members of society. There is a dearth of reading material, especially material accessible to the reader who has just gained literacy skills.

The research team found no youth groups in Afghanistan except for in Mazar-i-Sharif. Although many adolescents are already fully employed in paid work, many of them do have free time, and hanker after opportunities to prove themselves within their society. On the strength of interviews with this age-group, it appears that separate consultations with the adolescent girls and boys would yield ideas as to how they could act together to change their environment.

Parallel to efforts to give the population under the age of 18 a voice in the development of Afghanistan must be advocacy on behalf of this population by agencies. This advocacy will be most effective if it is based on inter-agency collaboration. A useful precedent has been set in Kabul where child-focused agencies meet on a regular basis. These include UNICEF, international NGOs and Afghan NGOs. 


\section{CONCLUSIONS AND RECOMMENDATIONS}

Whatever the future political developments that occur in Afghanistan, the children in Afghanistan, by the very fact that they are children, have a call on the four child-focused agencies that commissioned this report. They also have a call on the wider international community which has given its support to the UN Convention on the Rights of the Child. It is therefore imperative that ways are found to provide for the survival, protection, development and participation of Afghan children in the Afghanistan of the future.

This report has shown that the lives of children affected by the armed conflict in Afghanistan are characterised by uncertainty. Agencies too have to be prepared to adapt their programmes to changing security situations and to changing power structures. They have to plan for different scenarios with the aim of maintaining a long-term commitment to the children in the particular target community with which they choose to work until the point where their support is no longer necessary.

Gender discrimination, which begins at birth and besets the girl child through to womanhood, is preventing half the population from participating fully in the development of Afghanistan.

Particular attention should also be paid to the position of adolescent boys. Economic necessity, coercion and volunteering have been identified as the engines behind the continued involvement of adolescent boys in war. Poverty alleviation, the protection of vulnerable groups and education for peace are required to stop them.

At the same time all parties involved should act in unison at a regional and international level to put their weight behind efforts to secure a negotiated cessation to the fighting. Otherwise the armed conflict will continue to wreak havoc in every aspect of daily life.

Above all interventions should be designed to build a basis for optimism. This requires that they are built upon an understanding of the indigenous capacities and adaptive styles that Afghans have developed to cope with uncertainty, and the dissemination of examples of initiatives which have promoted the wellbeing of children.

\section{Recommendations}

1. Interventions on behalf of children in Afghanistan should be characterised by:

- Support for the efforts of Afghans who are working to relieve the suffering of children.

- Urgency because the development of children cannot be put on hold until there is a permanent cessation in the fighting.

- $\quad$ Flexibility in order to take advantage of changed and changing conditions.

- Long-term commitment because finding creative solutions to conflict situations within a community takes time.

- $\quad$ Advocacy at an international, regional and local level to ensure that those engaged in internal war, as well as those who benefit from its continuation, reach agreement on its termination and commence building a sustainable peace. 


\section{Every effort should be made to ensure that assistance is distributed evenly across regions.}

- $\quad$ Although the situation in each of the five zones visited is qualitatively different, children in each zone could benefit from interventions based on the criteria outlined in 1. above.

- Every effort should be made to disseminate good practice from one region to another. The most effective agents for change are individual Afghans with influence in their own community and the ability to act as an example to others.

- $\quad$ Recent internally displaced persons (IDPs) require help to survive if they have lost their assets and been cut off from their traditional networks of support. They need to be tracked across the country and their needs assessed with as little delay as possible.

- $\quad$ There is an urgent need to meet the survival needs of the inhabitants of Kabul.

- $\quad$ The conditions in certain urban centres, as well as some rural areas, still offer more opportunities to provide support to both girls and boys, women and men.

- In the Jalalabad zone it is possible to take advantage of the easier access to training facilities and documentation resources in Pakistan and the possibility of the exchange of experiences with the refugee population.

- $\quad$ Fewest agencies were found to be working specifically with children in Kandahar. In this zone long-term commitment is required to promote conditions favourable to the development of initiatives on behalf of children.

\section{Resources should be committed to research with children.}

- $\quad$ Action research would allow agencies to benefit from the lessons of experience in order to document good practice as well as learn from mistakes.

- The potential for greater participation by children in carrying out research should be reviewed. Child-to-child methods should be explored, particularly when working with adolescents, in order to gain a deeper knowledge of their responses to the complex questions relating to perceptions of reasons for war, adult role models, future aspirations and national identity.

- $\quad$ The principle of informed consent should be a basis for all research with children.

- Use of the appropriate language requires a knowledge on the part of researchers not only of official languages as taught in schools but also the local language as spoken by children.

- Longitudinal studies would allow for confidence between the researchers and the children to be built up over time. There is a range of issues which it was not possible to address through itinerant research, but which require the collaboration of agencies with deep local knowledge. These are issues relating to physical and sexual abuse, child prostitution and trafficking, and children in prisons.

- Greater understanding of the concept of childhood and the roles of children and young people in Afghanistan is required.

- Dialogue should be developed between the upholders of the Western tradition of individual human rights and the Islamic tradition of umma or Islamic community. 


\section{In their day-to-day practical operations international agencies working on behalf of children should:}

- $\quad$ Cooperate and avoid independence of action which can be a serious limitation to their effectiveness as advocates on behalf of children.

- Foster alliances with Afghan grassroots. If members of the community act as interlocutors with the authorities and make demands upon the indigenous authorities this reinforces a process which will contribute to the development of local accountability. It follows that there should be Afghan leaders and organisations who will act as leaven in their local community, and who will advocate the rights of children.

- Plan for the long term, and include staff and project participants in scenario planning so that they share a sense of the future.

- $\quad$ Analyse their impact on recipient communities.

- Develop a transparent exit strategy which is agreed with beneficiaries for when their assistance is no longer necessary.

\section{An analysis of vulnerability is critical to the design of interventions and should include:}

- Gender to ensure that any intervention takes account of the social roles of girls and boys, men and women, and does not support one group of people to the detriment of the other. Gender discrimination affects all members of the family, particularly in the case of children living in female-headed households. Women and girls should therefore have equal access to services of the same quality as men and boys.

- Disability to ensure that children with disabilities, and children living in households where there is a person with a disability, are involved in, not excluded from, programmes. While some agencies are already beginning to work intensively with certain groups of children with disabilities, a disability analysis needs to be applied at all levels of any programme of intervention, not merely to specialist projects.

- Conflict to ensure that conflict is neither created nor perpetuated in the provision of assistance. This involves mapping the divisions within the community, identifying the indigenous resources for managing conflict and identifying ways of coping with possible sources of friction, for example the influx of displaced people.

- $\quad$ Opportunities for members of vulnerable groups to define their own interests and determine their own development.

- Impact monitoring with respect to gender, disability and conflict. Indicators will have to be developed: one possible indicator is access to public space.

\section{Particular attention has to be paid to the views of adolescents.}

- $\quad$ Adolescent girls are the most secluded group within Afghan society.

- $\quad$ Adolescent boys are potential combatants and require alternative economic opportunities involving skills training and adult mentors.

- Both adolescent boys and girls are the next generation of parents and require preparation for this role. 


\section{Assistance to children should be part of a community-based approach.}

- $\quad$ Every effort should be made to ensure that the child is not separated from its family. Where children are living in institutions, every effort should be made to find and trace families and re-establish links and support the reunification if appropriate.

- The pressure on families should be reduced by creating individual and family-based productive livelihoods to help Afghans survive the current period, and to strengthen the family economy in a sustainable manner. This may mean that a programme to assist working children in fact provides economic opportunities for their parents.

- Alongside efforts to enhance people's abilities to help themselves, there should be investments in education, health and other social services, which families on their own are unable to provide.

\section{All educational programmes should be designed to:}

- $\quad$ Add to, rather than supplant, the efforts of parents to bring their children up. This means identifying the stresses which parents are under, and working to alleviate them, so that parents have more resources to devote to their children. A primary stress identified by the research was economic worries.

- Instil a much needed sense of security either through the establishment of a safe place or through routine.

- Supplement and enrich the educational activities in which children are already engaged. This would include dialogue with those responsible for the alternative education system based around the mosque, and discussion about how far this system could act as bridge to the formal education sector.

- Encourage the demilitarisation of children's imaginative domain. Already the key role of storytelling has been identified.

- Enhance and extend the formal education sector by identifying measures to increase the skills, status and morale of teachers and the availability of textbooks.

- $\quad$ Support those adults who provide adult role models applicable in peacetime, particularly to adolescents.

\section{Programming should create a climate of optimism.}

- $\quad$ Children are less polarised in their views than adults and their views should be made known.

- Terrain, culture and political conflict combine to hinder communication across Afghanistan. In order to mitigate this effect, efforts should be made to disseminate examples of good practice in programming for children, to provide inspiration and to create a climate of optimism.

- $\quad$ Radio ownership is widespread in Afghanistan. However, adults are preoccupied mainly with news of the armed conflict. If radio broadcasts were to encourage discussion of the invisible effects of the war, and to garner views of non-combatants, including children, listeners might be given a greater sense of their own participation in the future of their country. The radio could also broadcast news of initiatives which are making positive changes in the lives of children in Afghanistan. This good news could inspire some listeners to try and make similar initiatives within their own communities. 


\section{END NOTES}

1. Machel, Graça, Expert of the Secretary General of the United Nations, The Impact of Armed Conflict on Children, Briefing Notes on the Final Report A/51/306, p2

2. International Save the Children Alliance, Working Group on Children Affected by Armed Conflict and Displacement, Promoting Psychosocial Wellbeing among Children Affected by Armed Conflict and Displacement: Principles and Approaches, Working Paper No 1, November 1996, p7

3. Dubble, Cindy, Needs Assessment of Children Working in the Streets of Kabul, report prepared for Terre des Hommes, June 1996; Dubble, Cindy, Needs Assessment of Working Children in Mazar-iSharif, report prepared for Save the Children (UK), August 1997

4. Handicap International, A Household Survey in Kandahar Province, Afghanistan: Disability Prevalence, Rehabilitation Needs, Oral Polio Vaccine Coverage, June 1996

5. Gupta, Leila, report under preparation for UNICEF

6. SERVE's Hearing Impaired Project, Afghan Sign Language, 1995

7. Machel, Graça, ibid, p11

8. Dubble, Cindy, ibid

9. Abramson, Bruce, The Impact of Landmines on Children: Children's Rights in the Age of Landmines

10. Machel, Graça, ibid, p16

11. Dubble, Cindy, ibid

12. Brett, Rachel and McCallin, Margaret, Children: the Invisible Soldiers, Rädda Barnen Save the Children - Sweden, 1996

13. Hastie, Rachel, Disabled children in a society at war, a casebook from Bosnia, Oxfam UK and Ireland, 1997

14. Machel, Graca, ibid

15. CARE representative, Ghazni province, personal communication

16. Bracken, Patrick and Giller, Joan, The effect of war and post-traumatic stress disorder: a critical appraisal, presented to the conference "Rethinking the Trauma of War", Save the Children UK, May 1996

17. Summerfield, Derek, Trends in research and practice: who is leading whom?, paper presented to the conference "Rethinking the Trauma of War", Save the Children UK, May 1996

18. UN Inter-Agency Mission to Islamabad and Afghanistan 19 September - 15 October 1997, Draft strategic framework for international assistance in Afghanistan, UN New York, October 1997

19. UNICEF, Situation analysis of Afghan children and women, January 1992, p99

20. Hunte, Pamela, Social Communications and Afghans: continuity and change, report prepared for UNICEF, January 1992 


\section{APPENDIX I: TERMS OF REFERENCE}

\section{Background}

Afghanistan ranks 170 out of 174 according to the 1995 UNDP Human Development Index and bottom of the 130 countries on the UNDP Gender Development Index. Over 1.5 million people have been killed, including 300,000 to 400,000 children during 17 years of war.

The conflict has caused inestimable and widespread devastation to the economic, financial and social infrastructure. With very few human, capital or financial resources, the capability of local authorities to undertake the responsibilities of government, let alone investment in the social sector or any attempt at rehabilitation, is currently negligible. The ongoing fighting, or threats of fighting, continues to result in the bulk of existing resources being used for warfare or war readiness.

Violations of the Convention on the Rights of the Child (ratified by Afghanistan in March 1994) and the Convention on the Elimination of all Forms of Discrimination against Women (signed in 1980) are widespread, and many of these violations have now been institutionalised in directives issued by the Taliban authorities.

The situation for children continues to be among the worst in the world. About 3-4 million children are estimated to have died in the past 17 years from malnutrition and disease.

Malnutrition continues to affect 15-20\% of all children under 5 years old. Preventable diseases like diarrhoea, measles and acute respiratory infections contribute to an estimated 268,000 deaths annually of children under five years old, the equivalent of $50 \%$ of infant and child deaths, and one in four children will die before they reach the age of five. The largest cause of disability is thought to be polio, and more than one fifth of childhood deaths are caused by vaccinepreventable diseases. Many girls are currently not allowed to go to school as determined by political decree.

Afghans' lives since the start of the war have been characterised by multiple social and psychological problems. They have been exposed to a variety of traumatic stresses, one cause of which has been landmines. Afghanistan is one of the most heavily mined countries in the world with an estimated 10 million mines having been laid. Most Afghan children have witnessed and experienced the violence of war. Many of these children have endured both mental and physical suffering, having never lived in a stable family environment, having lost family members, become orphaned or been disabled by mines.

The situation for women is similarly very poor. The maternal mortality rate of 1,700 per 100,000 live births ranks Afghanistan as the second worst in the world; less than one in ten births are attended by a midwife; the TT2 coverage is $31 \%$; the literacy rate for women is officially listed as $15 \%$ but this figure is out of date and could now be as low as $3-4 \%$. Access by women to the meagre services that do exist is limited and often totally denied through a combination of cultural mores and, in some regions, political pressure or decree. The conservative views of the Taliban movement pose serious problems for women and girls particularly regarding employment, education and mobility. In addition, there are an estimated 700,000 widows in the country of which some 30,000 live in Kabul. 
At least 500,000 Afghans have been internally displaced within Afghanistan during the past two years; an estimated one million IDPs are at present dislocated within the country, the largest concentration of which, some 110,000 people, are living in camps around Jalalabad. Due to fighting since 1992, about half of the two million people living in the capital Kabul have fled the city and a further 250,000 were made homeless. Around 140,000 have been displaced from towns and villages to the north of Kabul since the beginning of 1997 due to the resurgence of fighting in this area.

\section{Children in Conflict Working Group}

A group of child-focused agencies working in Afghanistan, including Save the Children UK (SCF-UK), Save the Children Federation, Inc (SC-US), Rädda Barnen and UNICEF, has been meeting on a regular basis throughout 1996 to discuss issues relating to Children in Conflict. The aims of the group are to share information on children, to raise awareness of the issues confronted by children affected by conflict and to devise strategies to address the effects of conflict on children.

The Graça Machel study to the United Nations titled "The Impact of Armed Conflict on Children" highlights the need for humanitarian agencies to focus on children and support them in the realisation of their rights. The agencies in the Working Group are committed to helping Afghan children and their families realise these rights even in the face of conflict. However, time constraints and limited expertise make it difficult for the member agencies to devote full attention to the creation of a plan of action.

\section{Considerations}

- the conflict has had multiple physical, social and emotional effects on Afghan children. Among the most important concerns of the Working Group that are to be the primary focus of the proposed study are child soldiers, disability, displaced persons, landmines and UXOs, and working children;

- more detailed information on the situation of children is required, both in order to plan appropriate interventions, to advocate for children in conflict and to contribute to an international body of knowledge on children in conflict;

- to appropriately address the needs of Afghan children the most vulnerable groups need to be identified and targeted;

- experiences of agencies working in other conflict situations should be used to assist in the development of strategies to address the needs of Afghan children;

- the member agencies of the Working Group need additional capacity to carry out a situation analysis and needs assessment vis-à-vis children in conflict.

\section{Proposed Study - Objective}

It is therefore proposed that a consultant be employed to carry out a needs assessment and a situation analysis of the effects of conflict on the rights of the child in Afghanistan as understood in the Convention on the Rights of the Child, with specific reference to child soldiers, disability, displaced persons, landmines and UXOs, working children and the social effects of the war. 


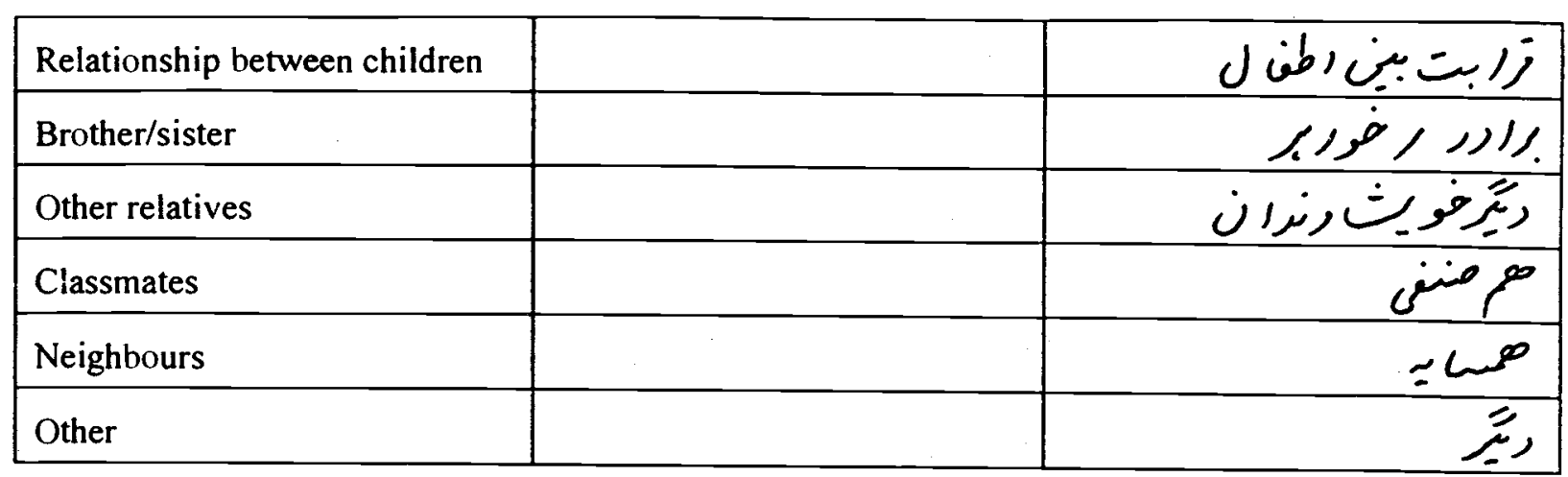

Other observations:

-

eg adult present, mood and concentration of children, interruptions, social and economic circumstances

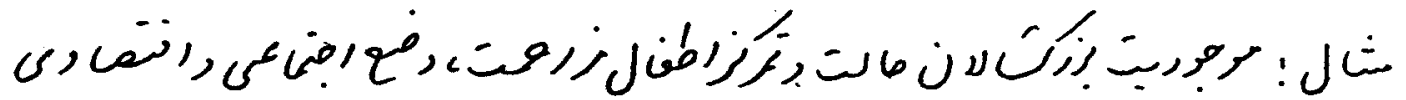

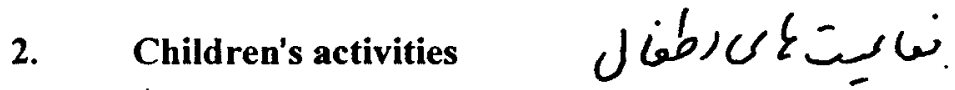

The interviewer should choose which set of questions to begin with

Education if children are studying

Work if children are working

(

Freetime if children are not studying or working 
ENGLISH - DAR VERSION

Children in Conflict, Questionnaire

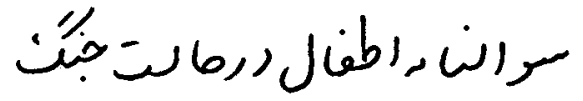

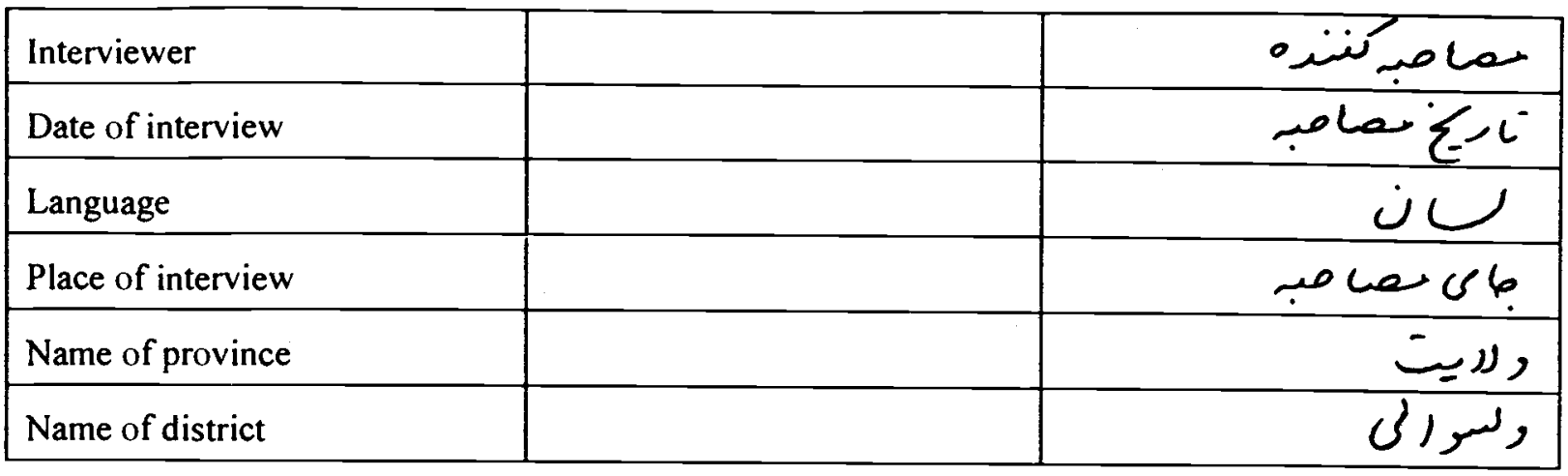

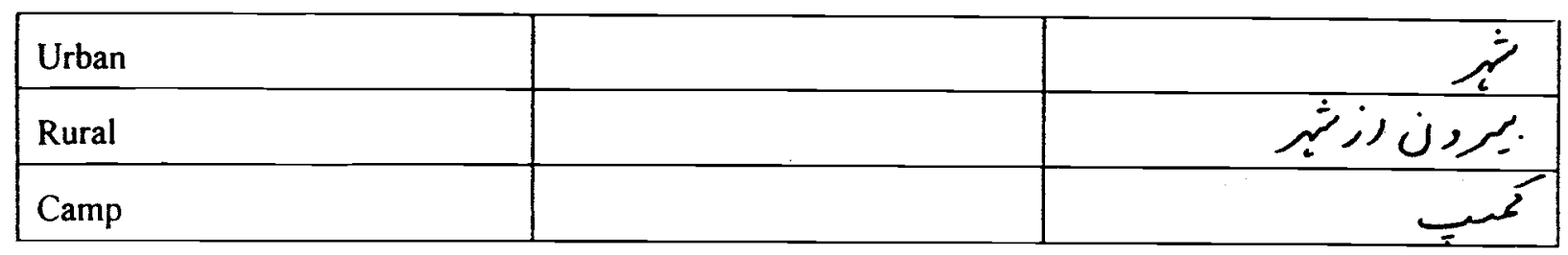

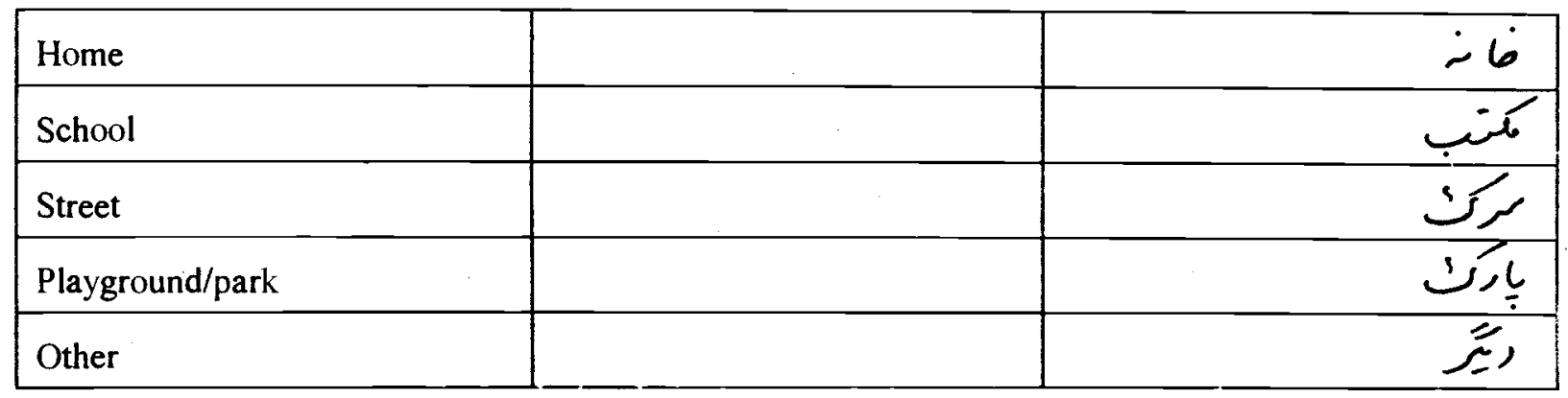

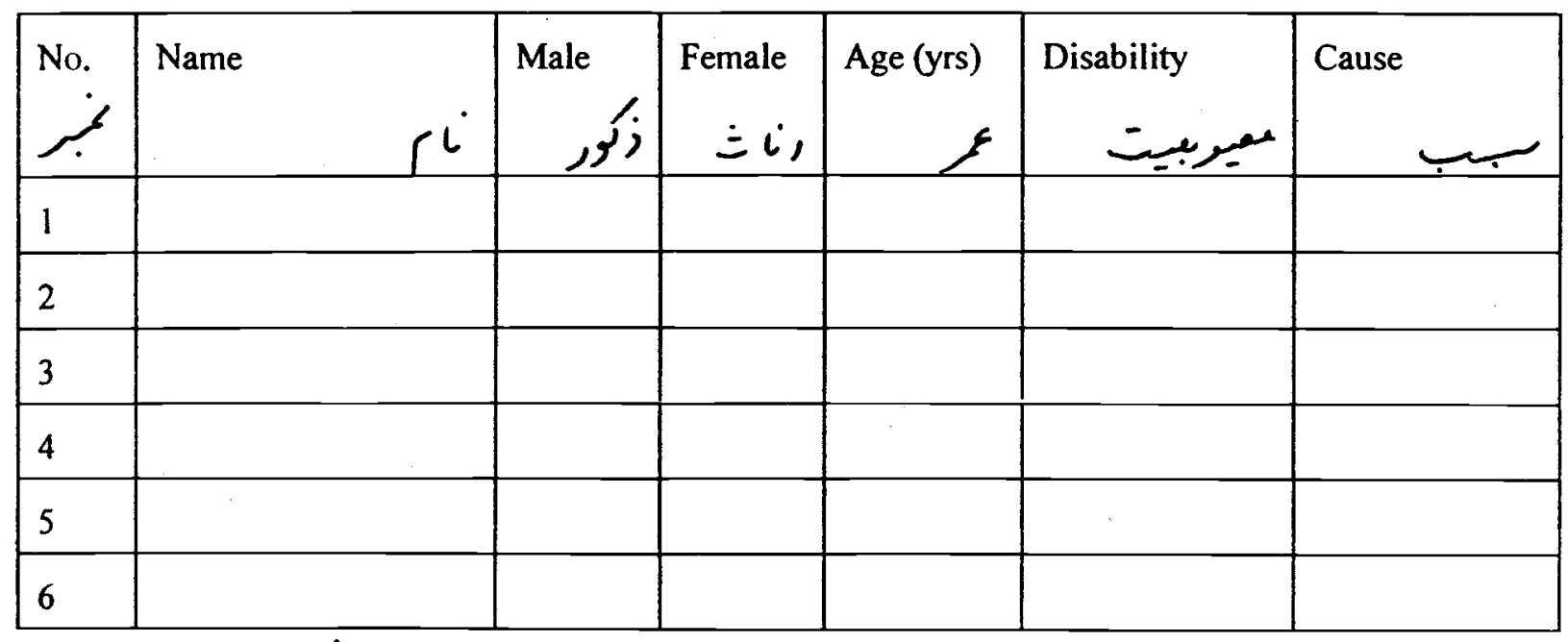

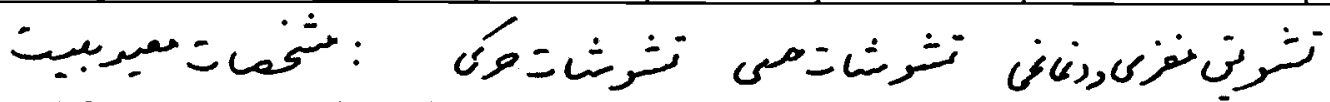

Disability please specify: mobility impairment, sensory impairment, mental impairment

"Cause please specify: war, disease (eg polio), birth complication (eg cerebral palsy), other

This question may be asked later in the interview to avoid anyembarassment to child

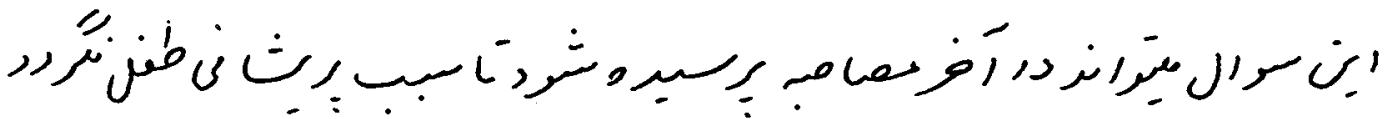


2.2 Work

What kind of work do you do in the house?

\begin{tabular}{|l|l|l|l|l|l|l|l|}
\hline Child no. & 1 & 2 & 3 & 4 & 5 & 6 & \\
\hline $\begin{array}{l}\text { Wash dishes/clothes, cook, } \\
\text { sweep }\end{array}$ & & & & & & & \\
\hline Collect water & & & & & & & \\
\hline Child care & & & & & & & \\
\hline Carpet weaving & & & & & & & \\
\hline Other & & & & & & & \\
\hline
\end{tabular}

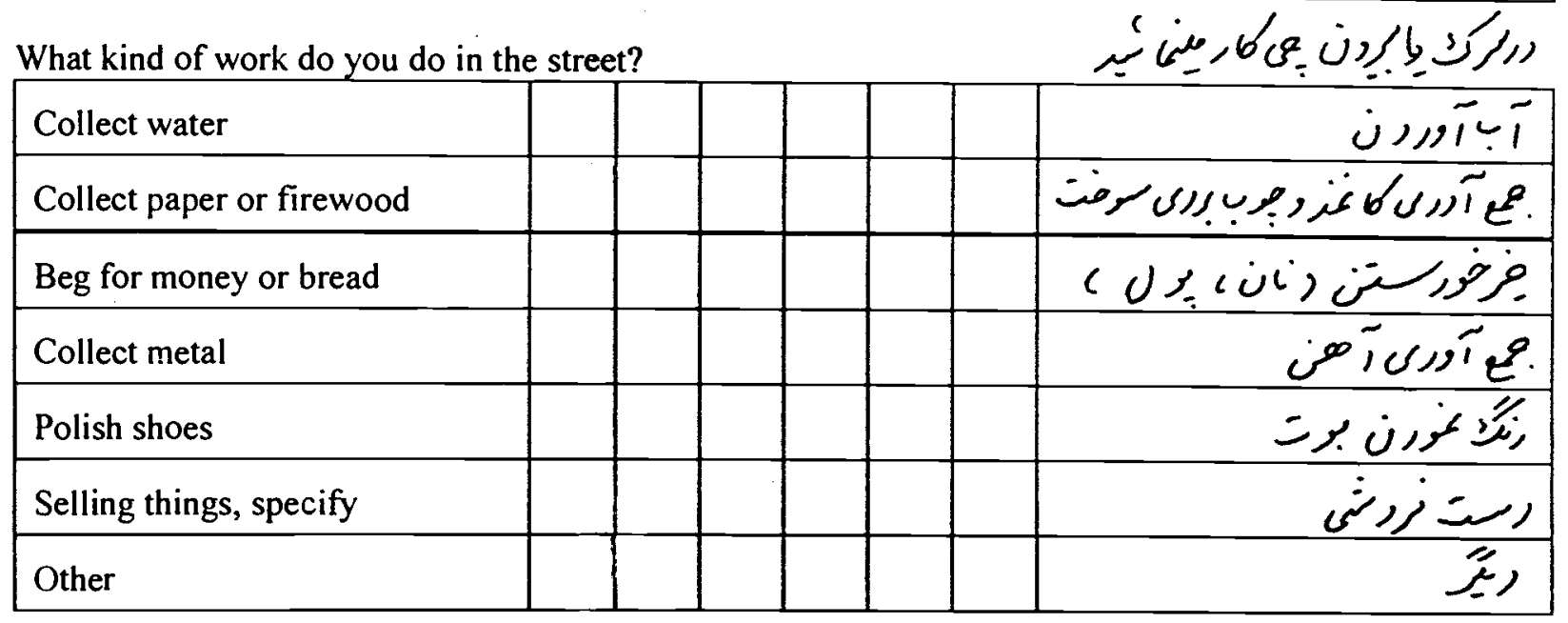

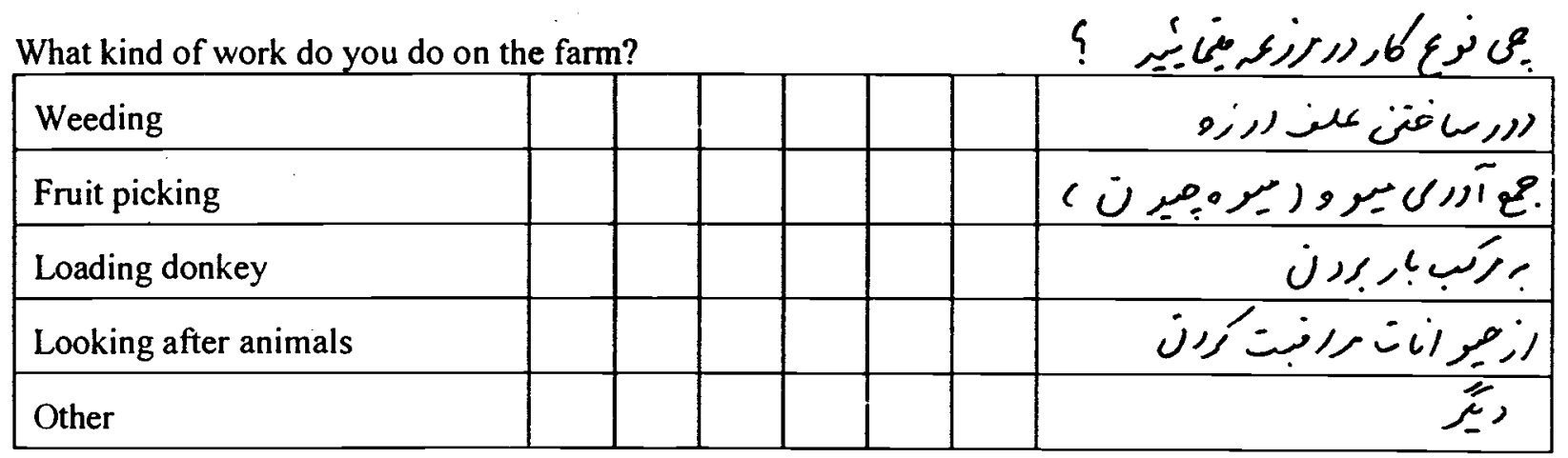

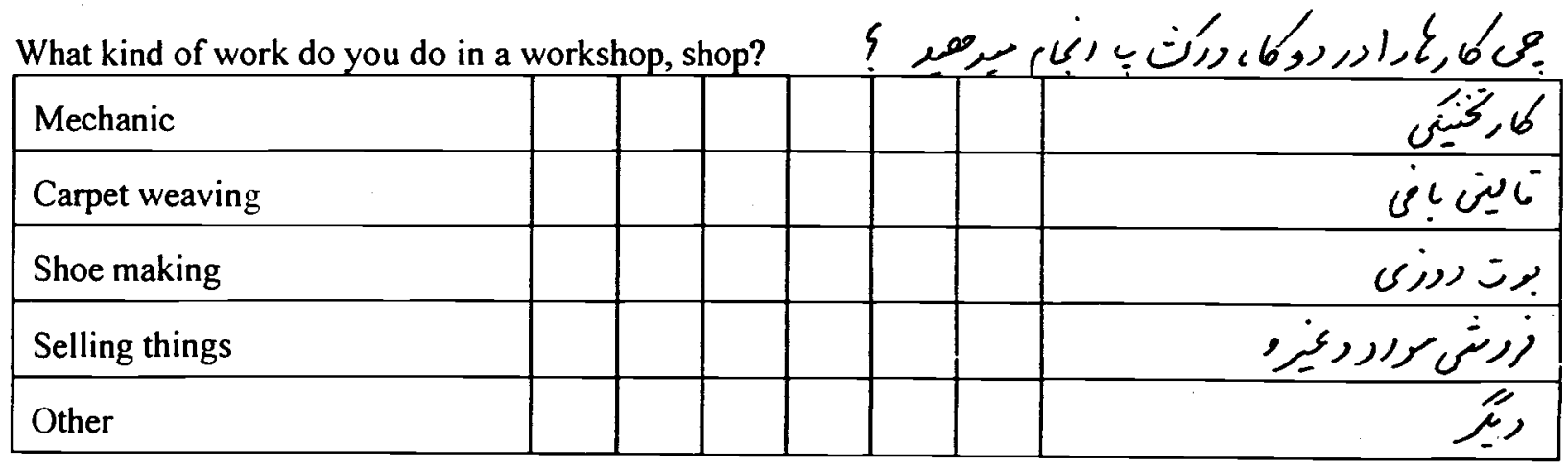


2.1 Education

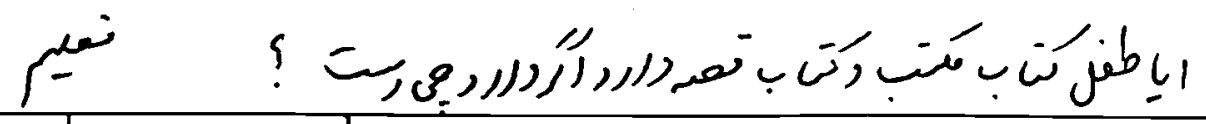

\begin{tabular}{|l|l|l|l|}
\hline Child no. & Years in school & Now in school? & $\begin{array}{l}\text { Does the child have any school or story books at } \\
\text { home? } \\
\text { If yes, what are they? }\end{array}$ \\
\hline 1 & & & \\
\hline 3 & & & \\
\hline 4 & & & \\
\hline 5 & & & \\
\hline 6 & & & \\
\hline
\end{tabular}

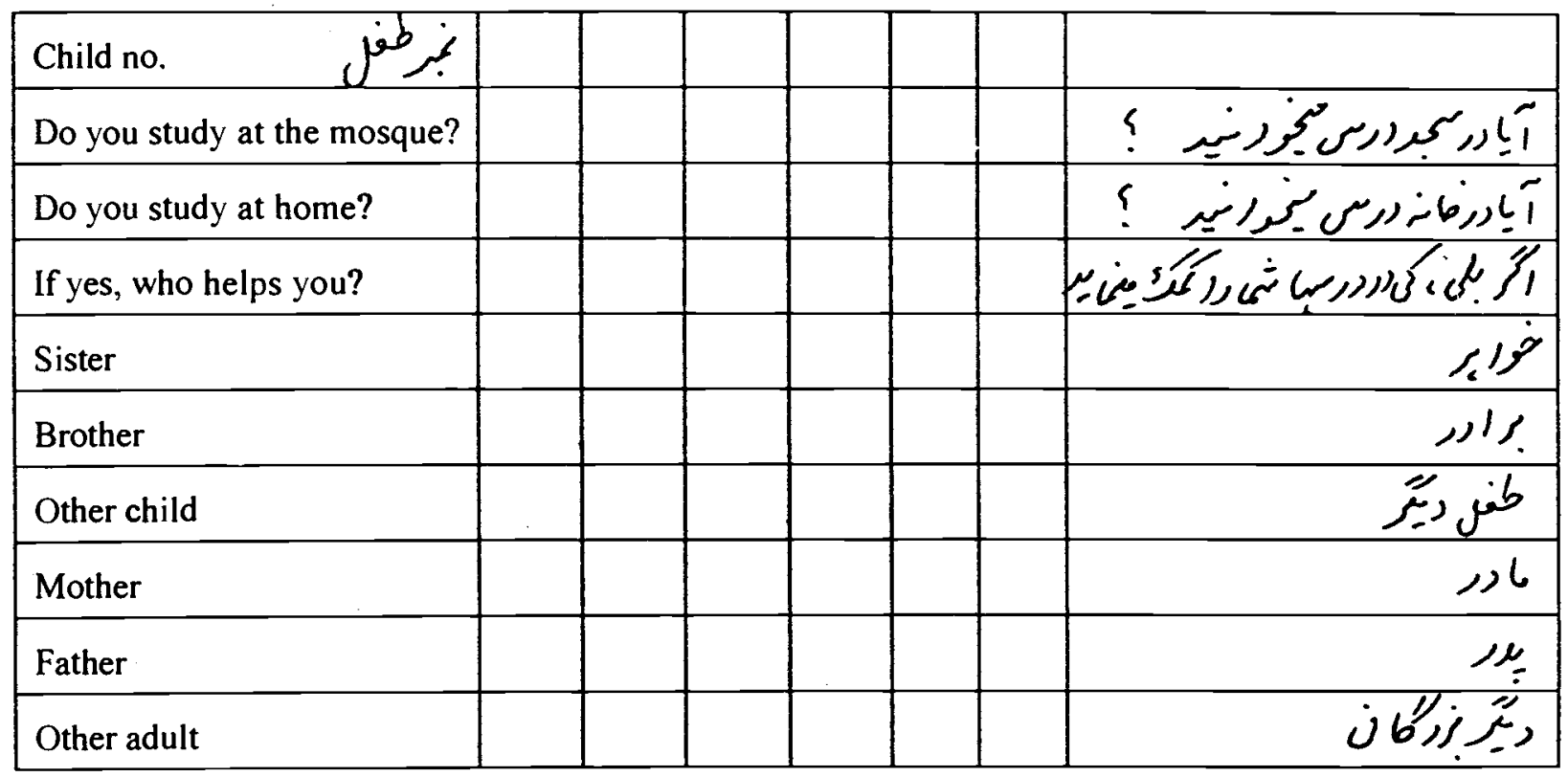

If you stopped attending school, what was the reason?

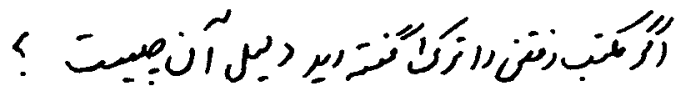

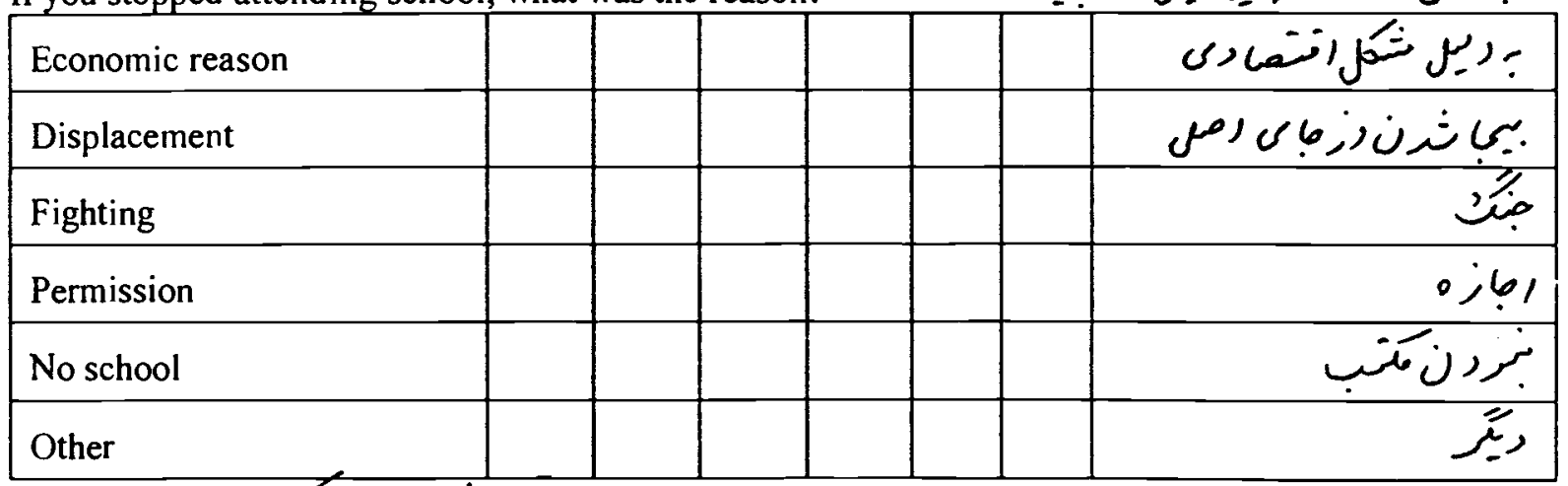

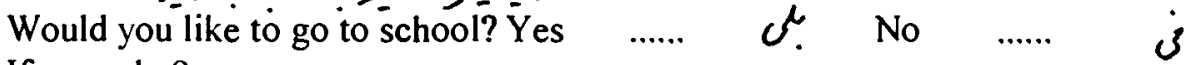
If yes, why? 
2.3 Free time

\begin{tabular}{|l|l|l|l|l|l|l|r|}
\hline Child no. & 1 & 2 & 3 & 4 & 5 & 6 & $j$ \\
\hline Do you have any free time? & & & & & & & \\
\hline
\end{tabular}

What games do you play?

$$
\begin{aligned}
& 5
\end{aligned}
$$

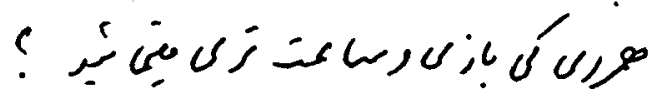

Who do you play with?

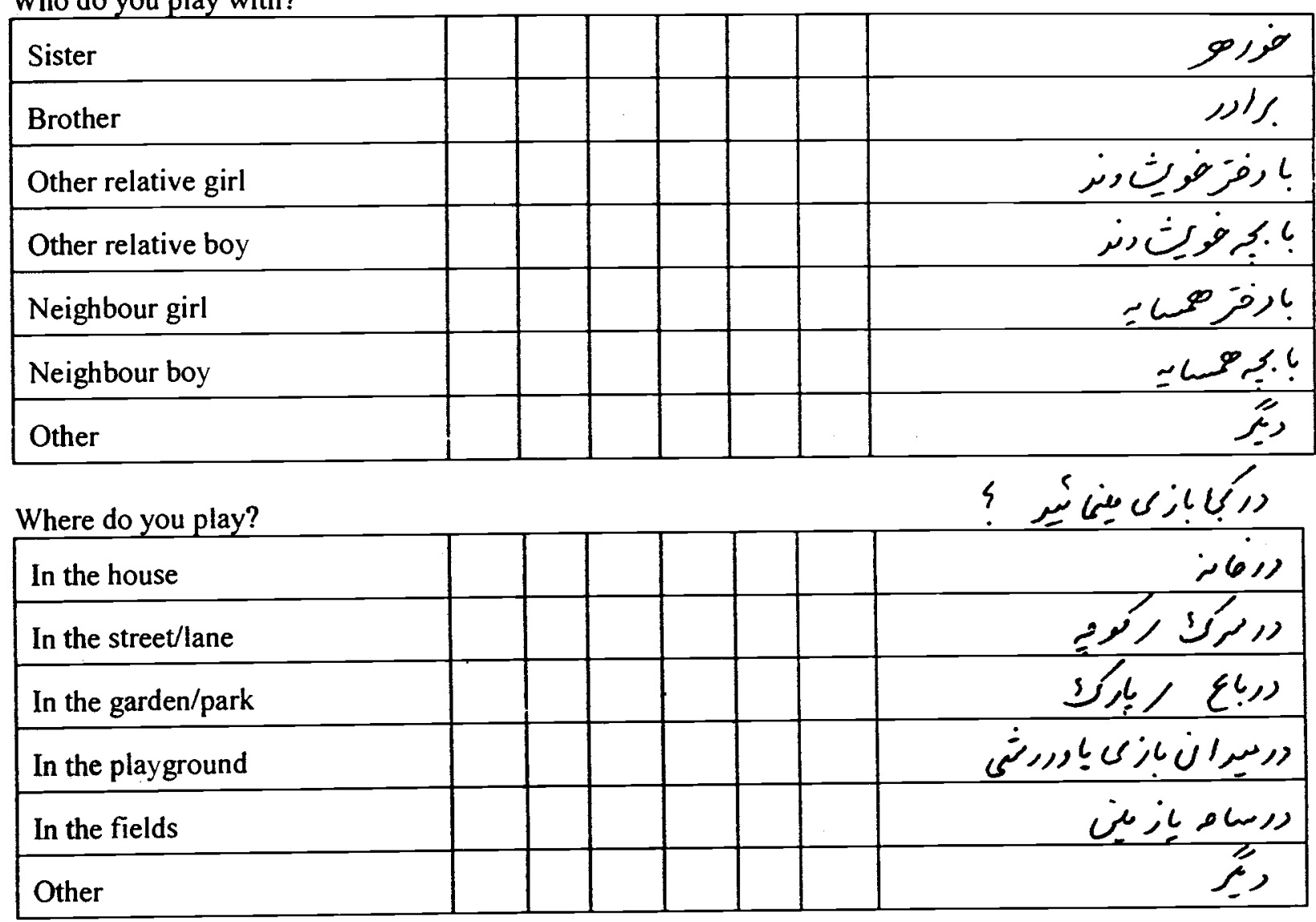

What games did you play before the war?

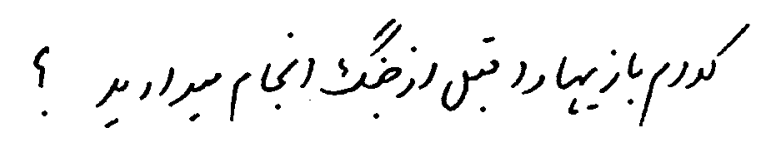

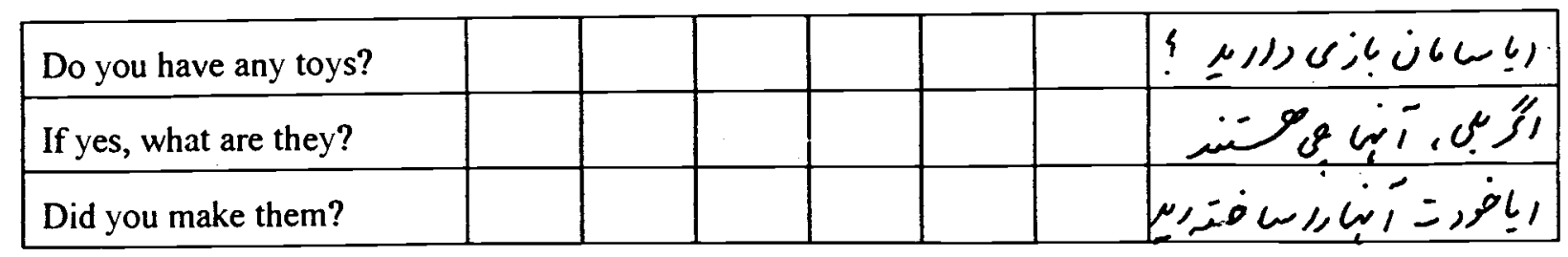




\begin{tabular}{|c|c|c|c|c|c|c|c|}
\hline Child no. & 1 & 2 & 3 & 4 & 5 & 6 & بر طنز \\
\hline $\begin{array}{l}\text { Do you earn money for your } \\
\text { work? }\end{array}$ & & & & & & & $؟ \underline{\mu}$ \\
\hline $\begin{array}{l}\text { How much money do you earn } \\
\text { each day? }\end{array}$ & & & & & & & 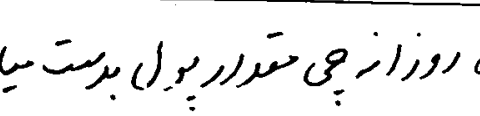 \\
\hline
\end{tabular}

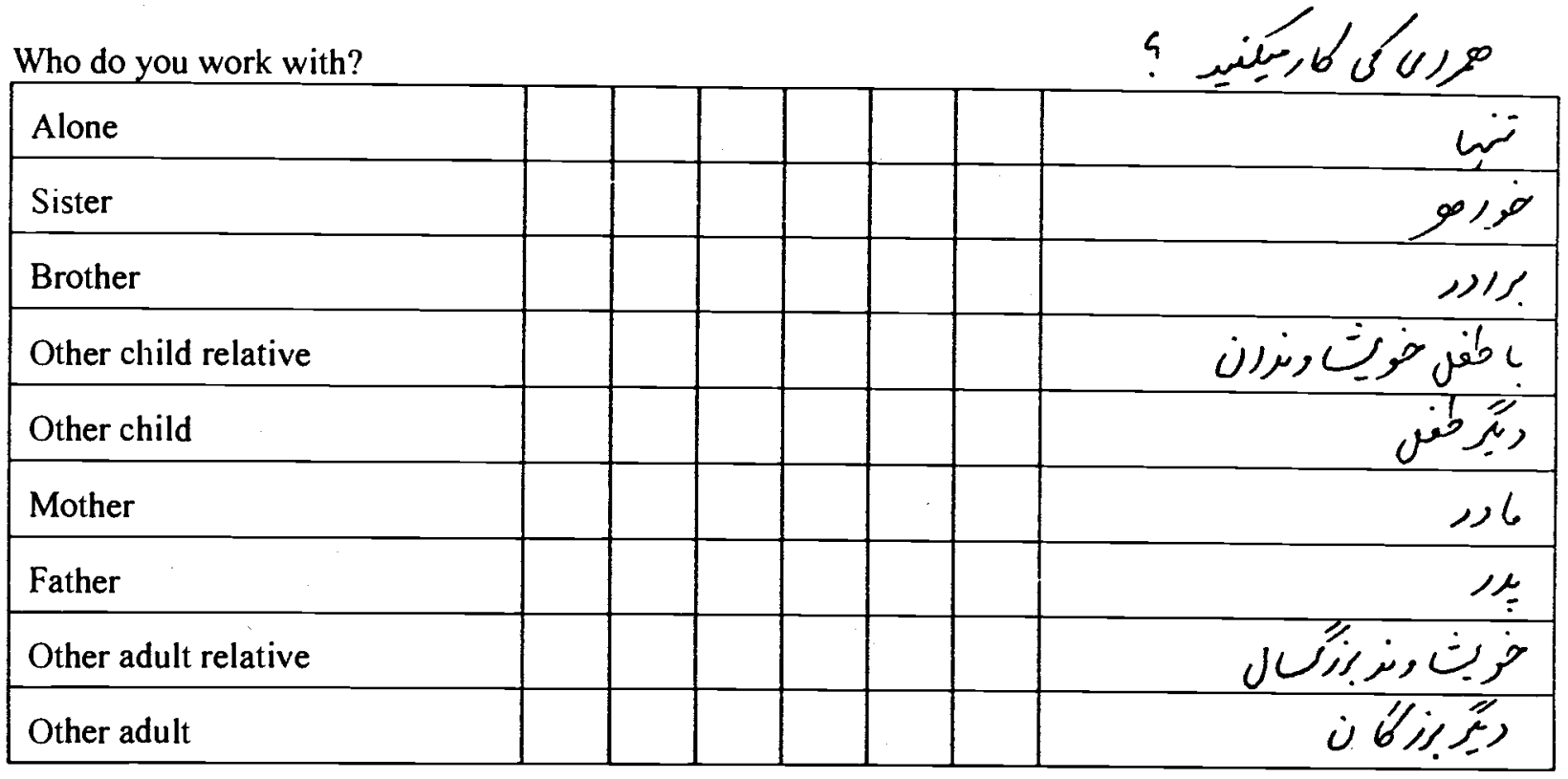


3. Past

Can you tell me an unforgettable story from your life?

(For individual interview only)

$$
\text { (U) }
$$

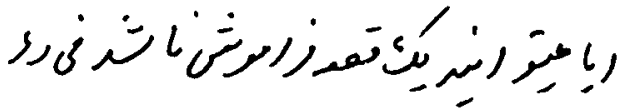

$$
\begin{aligned}
& \text { r }
\end{aligned}
$$

4. Family and living situation:

\begin{tabular}{|c|c|c|c|c|c|c|c|c|c|c|}
\hline & $\begin{array}{l}\text { Father } \\
\text { present } \\
\text { and } \\
\text { healthy } \\
\text { heals }\end{array}$ & $\begin{array}{l}\text { Father } \\
\text { present } \\
\text { but } \\
\text { sick } \\
\text { ielle }\end{array}$ & 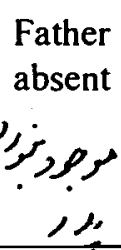 & $\begin{array}{l}\text { Father } \\
\text { dead } \\
=\text { عرنرم, }\end{array}$ & $\begin{array}{l}\text { Mother } \\
\text { present } \\
\text { and } \\
\text { healthy }\end{array}$ & 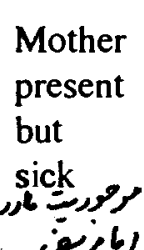 & 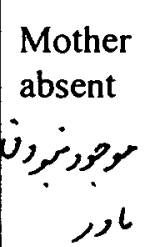 & $\begin{array}{l}\text { Mother } \\
\text { dead } \\
=\text { عنررمر }\end{array}$ & 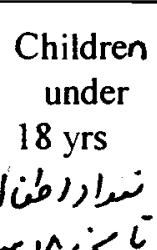 & 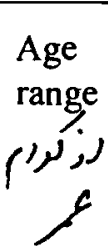 \\
\hline 1 & & & & & & & & & & \\
\hline 2 & & & & & & & & & & \\
\hline 3 & & & & & & & & & & \\
\hline 4 & & & & & & & & & & \\
\hline 5 & & & & & & & & & & \\
\hline 6 & & & & & & & & & & \\
\hline
\end{tabular}

w isisis

\begin{tabular}{|c|c|c|c|c|}
\hline Child no. & $\begin{array}{l}\text { Have you } \\
\text { ever been a } \\
\text { refugee? } \\
940646 \\
94,2,4\end{array}$ & $\begin{array}{l}\text { Have you } \\
\text { ever been } \\
\text { displaced? }\end{array}$ & $\begin{array}{l}\text { Are you still } \\
\text { displaced? }\end{array}$ & 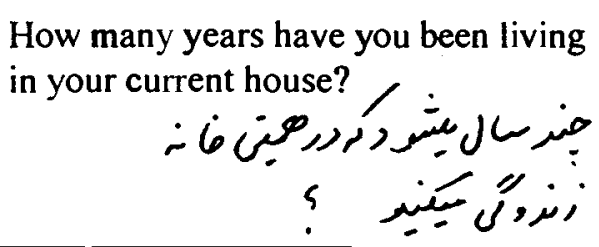 \\
\hline 1 & - & & & \\
\hline 2 & & & & \\
\hline 3 & & & & \\
\hline 4 & & & & \\
\hline 5 & & & & \\
\hline 6 & & & & \\
\hline
\end{tabular}


Do adults ever tell you stories?

\begin{tabular}{|c|c|c|c|c|c|c|}
\hline 1 & 2 & 3 & 4 & 5 & 6 & \\
\hline & & & & & & קונן \\
\hline & & & & & & 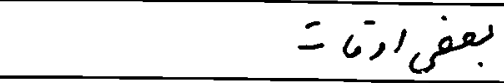 \\
\hline & & & & & & 'b' \\
\hline
\end{tabular}

If yes, who tells you stories?

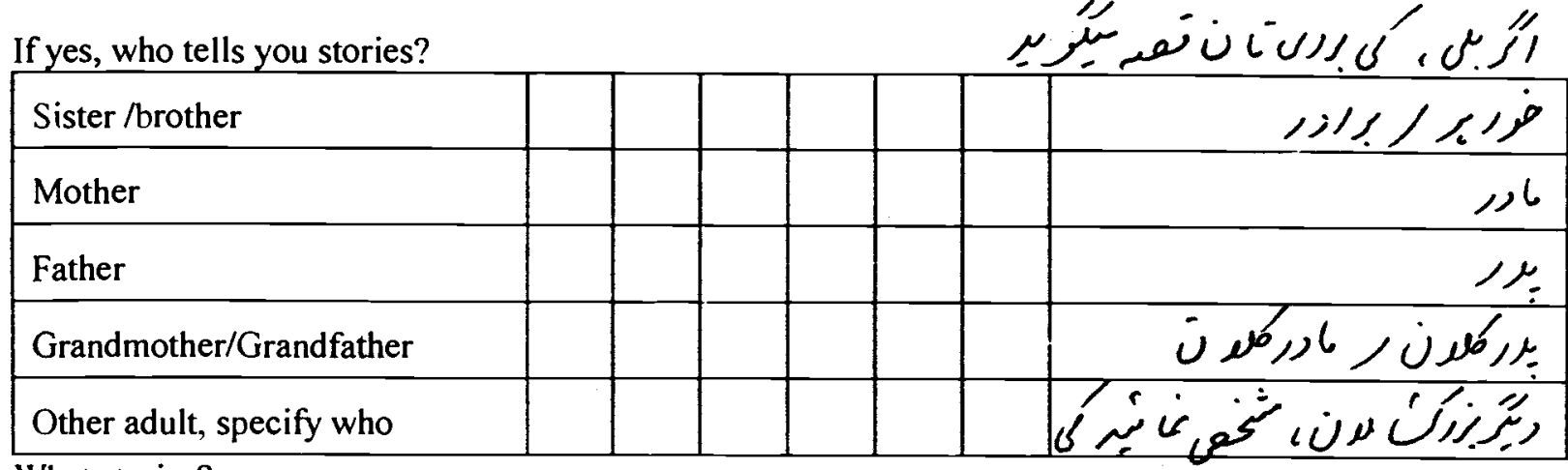

What stories?

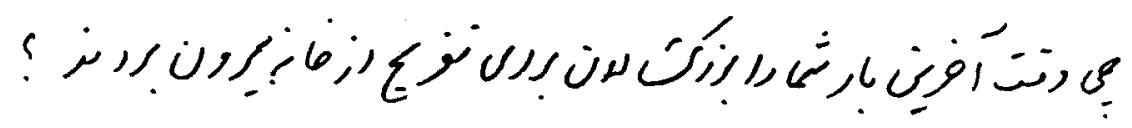

When was the last time adults took you outside the house for a picnic?

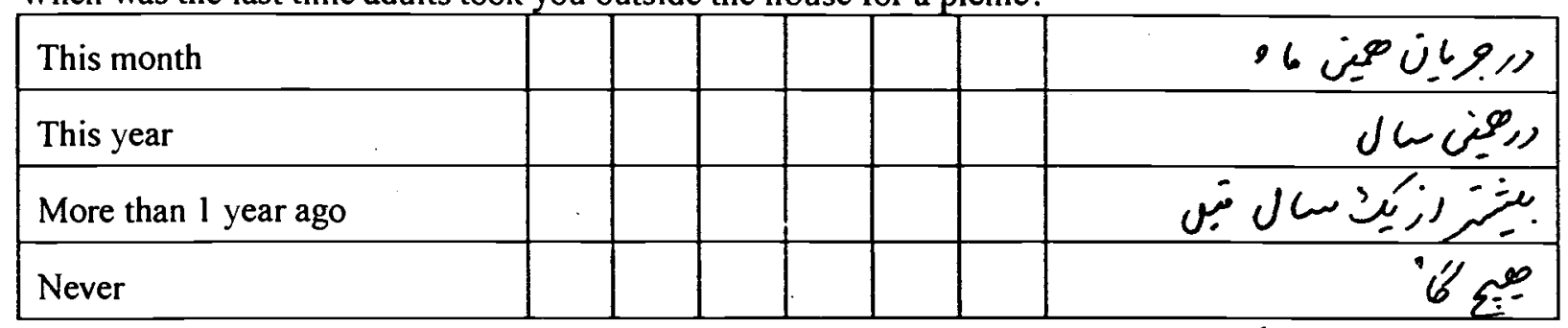

Where do you go during the twoEids?

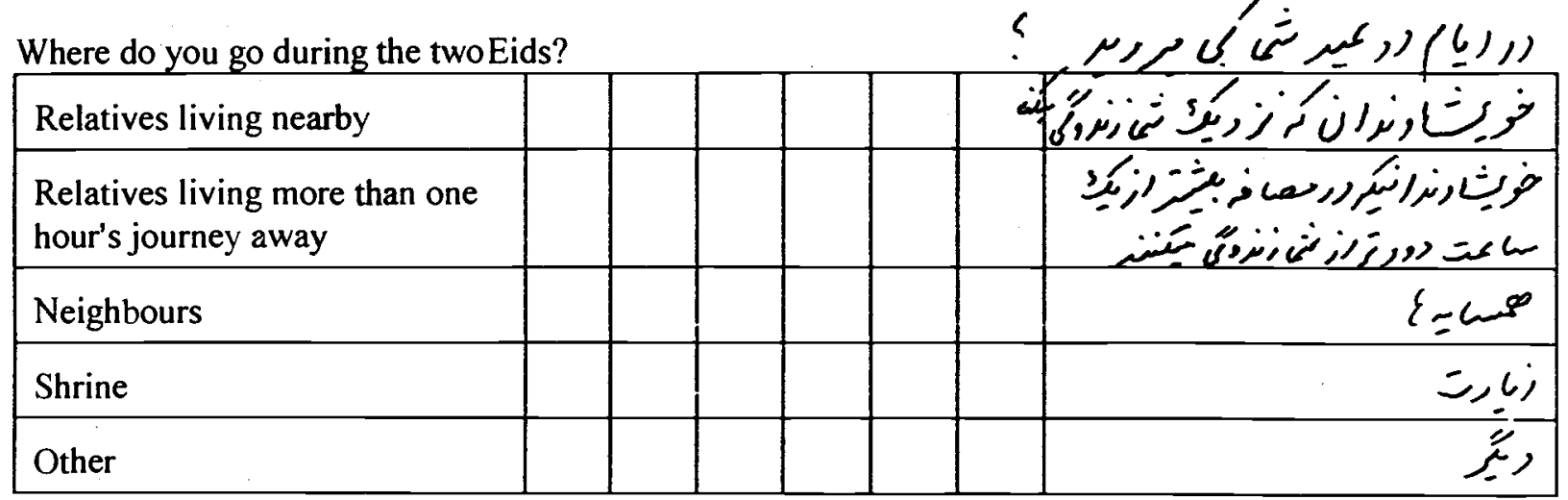

When was the last time you went to a wedding party?

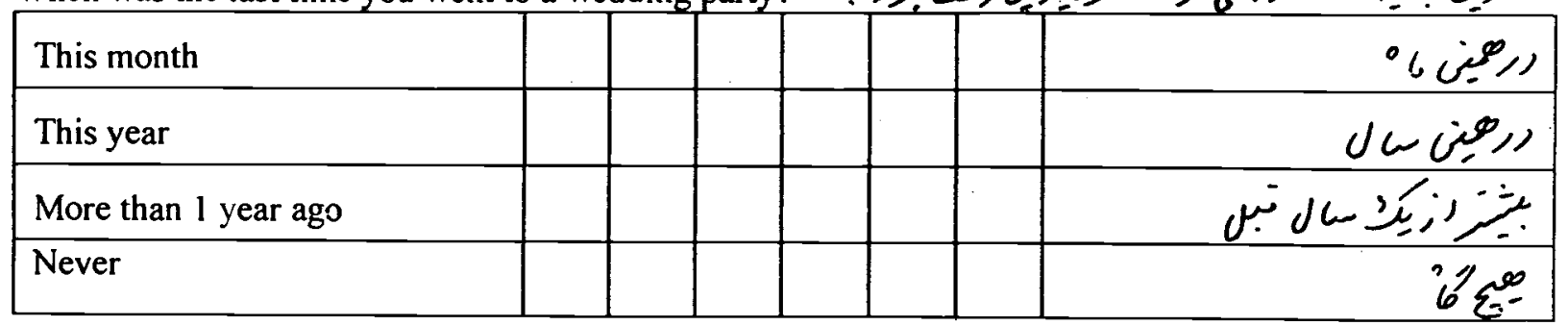




\section{Methodology}

The emphasis of the study will be on compiling qualitative information on the subject matter outlined in paragraph 4 above, and to include a series of case studies, interviews with children, adults and agency representatives, and a library search.

\section{Output}

The consultant will work to the following terms of reference:

6.1 To produce a written report on the effects of conflict in Afghanistan on the psycho-social well-being of children, with special reference to child soldiers, disability, displaced persons, landmines and UXOs, and working children. The report will include:

a) a situation analysis

b) a needs assessment

c) an investigation of current and planned programmes with special reference to identifying and recommending types of effective interventions to benefit traumatised children.

This report will be used for distribution and advocacy within Afghanistan and internationally. A presentation of the results and observations of the study will be made by the consultant to the supporting agencies.

6.2 To recommend priority issues to be considered for further in-depth studies.

6.3 To recommend future steps for the gathering and dissemination of information on the abovementioned topics for the purpose of advocacy and future programme interventions.

6.4 To recommend possible areas of project implementation

\section{Travel}

Visits should be made to all five regions - north, south, west, east and central - covered from Kabul, Jalalabad, Mazar-i-Sharif, Herat and Kandahar, ensuring both rural and urban representation in each region. 
5. War

\begin{tabular}{|c|c|c|c|c|}
\hline $\begin{array}{l}\text { Child } \\
\text { no. } \\
\text { زبر }\end{array}$ & $\begin{array}{l}\text { Have any of } \\
\text { your relatives } \\
\text { died during the } \\
\text { war? }\end{array}$ & $\begin{array}{l}\text { Do you know of any } \\
\text { children injured by the } \\
\text { war? }\end{array}$ & $\begin{array}{l}\text { Has your own home } \\
\text { ever been destroyed or } \\
\text { hit? }\end{array}$ & $\begin{array}{l}\text { Do you know of any } \\
\text { children who have } \\
\text { become soldiers? } \\
\text { Specify age }\end{array}$ \\
\hline 1 & & & & \\
\hline 2 & & & & \\
\hline 3 & & & & \\
\hline 4 & & & & \\
\hline 5 & & & & \\
\hline 6 & & & & \\
\hline
\end{tabular}

Do adults talk with you about the war?

\begin{tabular}{|c|c|c|c|c|c|c|c|}
\hline Child no. & 1 & 2 & 3 & 4 & 5 & 6 & برقون \\
\hline Mother & & & & & & & ا \\
\hline Father & & & & & & & ב! \\
\hline Other female relative & & & & & & & توزي \\
\hline \multicolumn{8}{|l|}{ Other male relative } \\
\hline \multicolumn{8}{|l|}{ Teacher } \\
\hline Other adult & & & & & & & 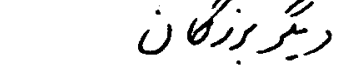 \\
\hline
\end{tabular}




\begin{tabular}{|c|c|c|c|c|c|c|c|}
\hline Child no. & 1 & 2 & 3 & 4 & 5 & 6 & كز \\
\hline Do you have a radio? & & & & & & & إِرות \\
\hline Do you listen to Sharia & & & & & & & 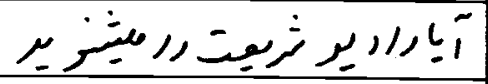 \\
\hline New Life New Home & & & & & & & 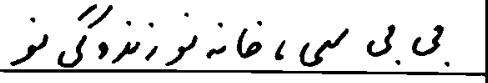 \\
\hline BBC News & & & & & & & امباربق كى مع \\
\hline Pakistan radio & & & & & & & را \\
\hline Other? & & & & & & & Ё \\
\hline
\end{tabular}

6. Future

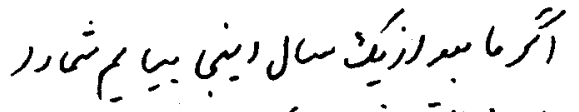

If we came back in 1 year's time would we find you here?

\begin{tabular}{|c|c|c|c|c|c|c|c|}
\hline Child no. & 1 & 2 & 3 & 4 & 5 & 6 & كخر طنر \\
\hline Yes & & & & & & & 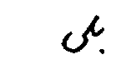 \\
\hline No & & & & & & & 3 \\
\hline Don't know & & & & & & & كمرر \\
\hline
\end{tabular}

Who would you like to be like when you are older?

When you have children, what kind of life do you want to give them?

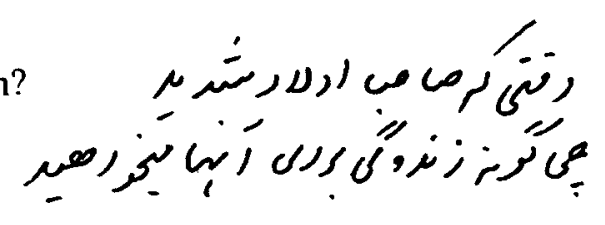

We are now going to Kabul, Jalalabad, Kandahar, Herat, Mazar, what message do you have for children there?

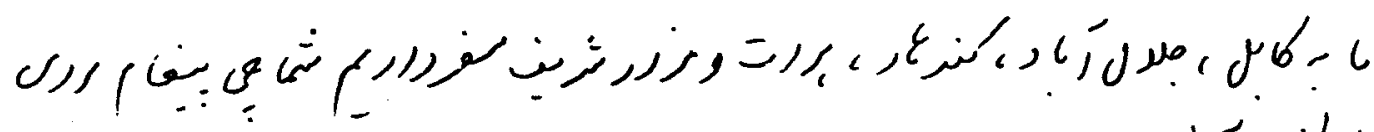

$$
\begin{aligned}
& \text { s }
\end{aligned}
$$




\section{APPENDIX-II ENGLISH - PASHTO VERSION}

Children in Conflict, Questionnaire

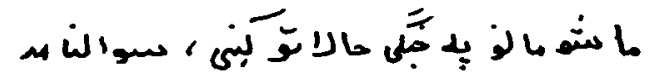

\begin{tabular}{|c|c|}
\hline Interviewer & 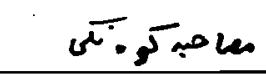 \\
\hline Date of interview & رساحجى مند \\
\hline Language & د ماجيى زبه \\
\hline Place of interview & 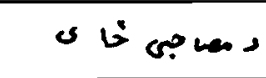 \\
\hline Name of province & $r \neq \tau 1 s, s$ \\
\hline Name of district & د, لسو'ل لز م \\
\hline
\end{tabular}

\begin{tabular}{|l|l|r|}
\hline Urban & & \\
\hline Rural & & sis s \\
\hline Camp & & s. \\
\hline
\end{tabular}

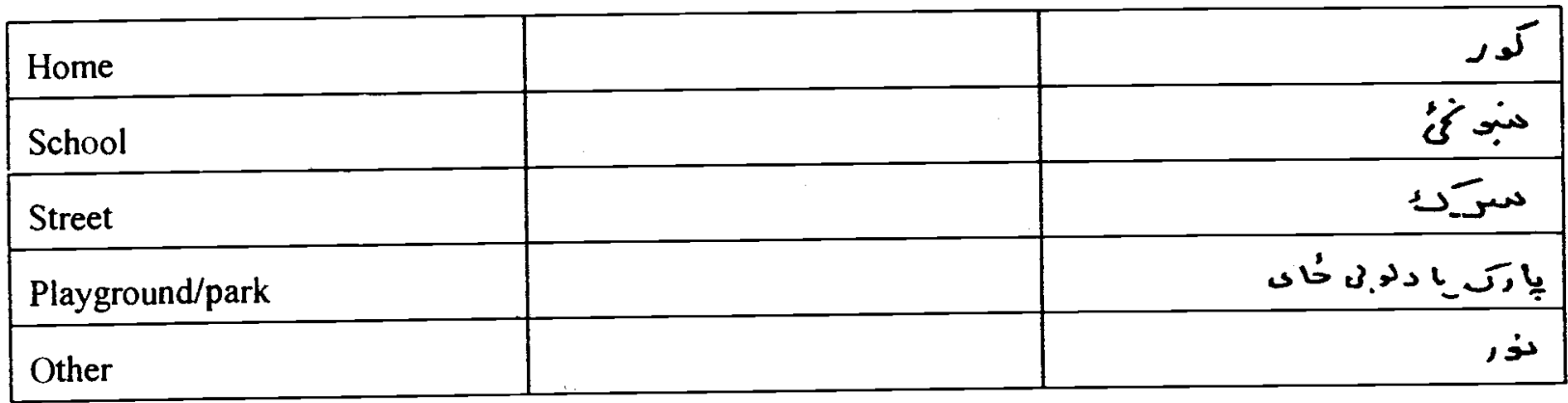

\begin{tabular}{|c|c|c|c|c|c|c|}
\hline No. & ل & $\begin{array}{l}\text { Male } \\
\qquad \stackrel{i}{=}\end{array}$ & 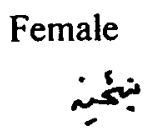 & $\begin{array}{r}\text { Age (yrs) } \\
\text { sم }\end{array}$ & 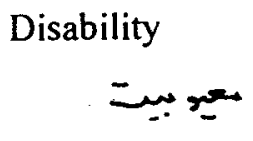 & 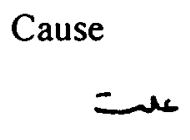 \\
\hline 1 & & & & & & \\
\hline 2 & & & & & & \\
\hline 3 & & & & & & \\
\hline 4 & & & & & & \\
\hline 5 & & & & & & \\
\hline 6 & & & & & & \\
\hline
\end{tabular}

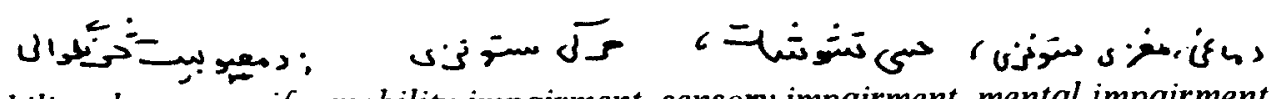
Disability please specify: mobility impairment, sensory impairment, mental impairment

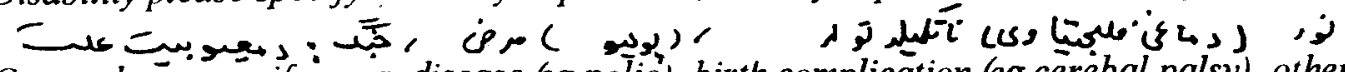
Cause please specify: war, disease (eg polio), birth complication (eg cerébal palsy), other

This question may be asked later in the interview to avoid anyembarassment to child

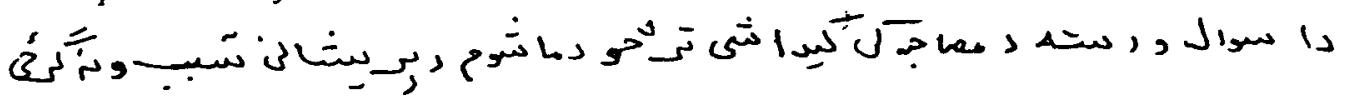




\begin{tabular}{|c|c|}
\hline Relationship between children & 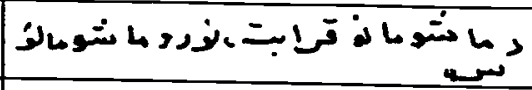 \\
\hline Brother/sister & و, \\
\hline Other relatives & ذُر خلصان \\
\hline Classmates & ن ines \\
\hline Neighbours & ن \\
\hline Other & 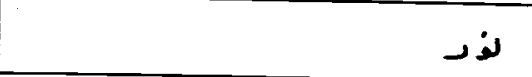 \\
\hline
\end{tabular}

Other observations:

eg adult present, mood and concentration of children, interruptions, social and economic circumstances

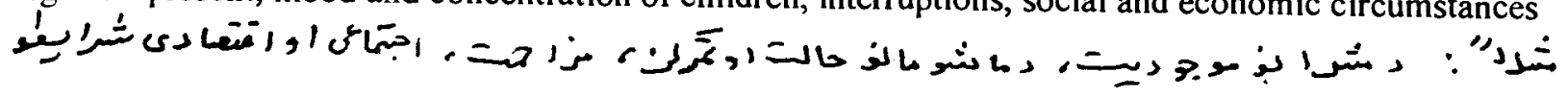

\section{Children's activities $\quad$ is}

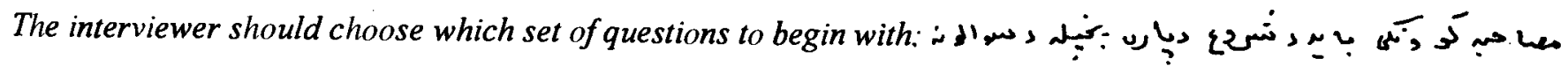

Education if children are studying

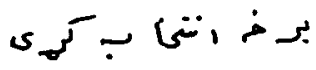

Work if children are working

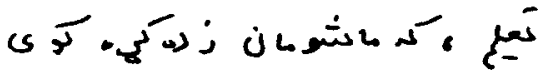

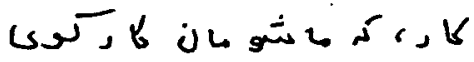

Freetime if children are not studying or working

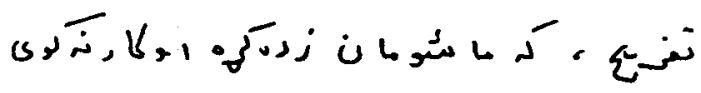




\begin{tabular}{|c|c|c|c|}
\hline $\begin{array}{l}\text { Child no. } \\
\text { داستُدك نمبح }\end{array}$ & $\begin{array}{l}\text { Years in school } \\
\text { هنبو, غة كلد ה: }\end{array}$ & 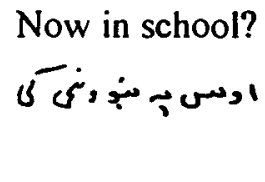 & 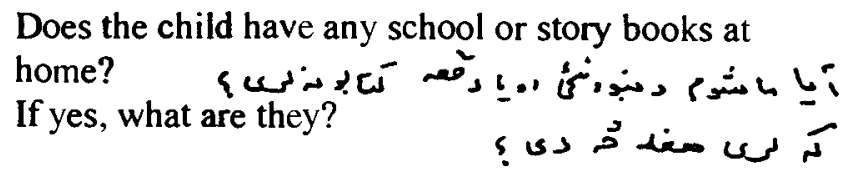 \\
\hline 1 & & & \\
\hline 2 & & & \\
\hline 3 & & & \\
\hline 4 & & & \\
\hline 5 & & & \\
\hline 6 & & & \\
\hline
\end{tabular}

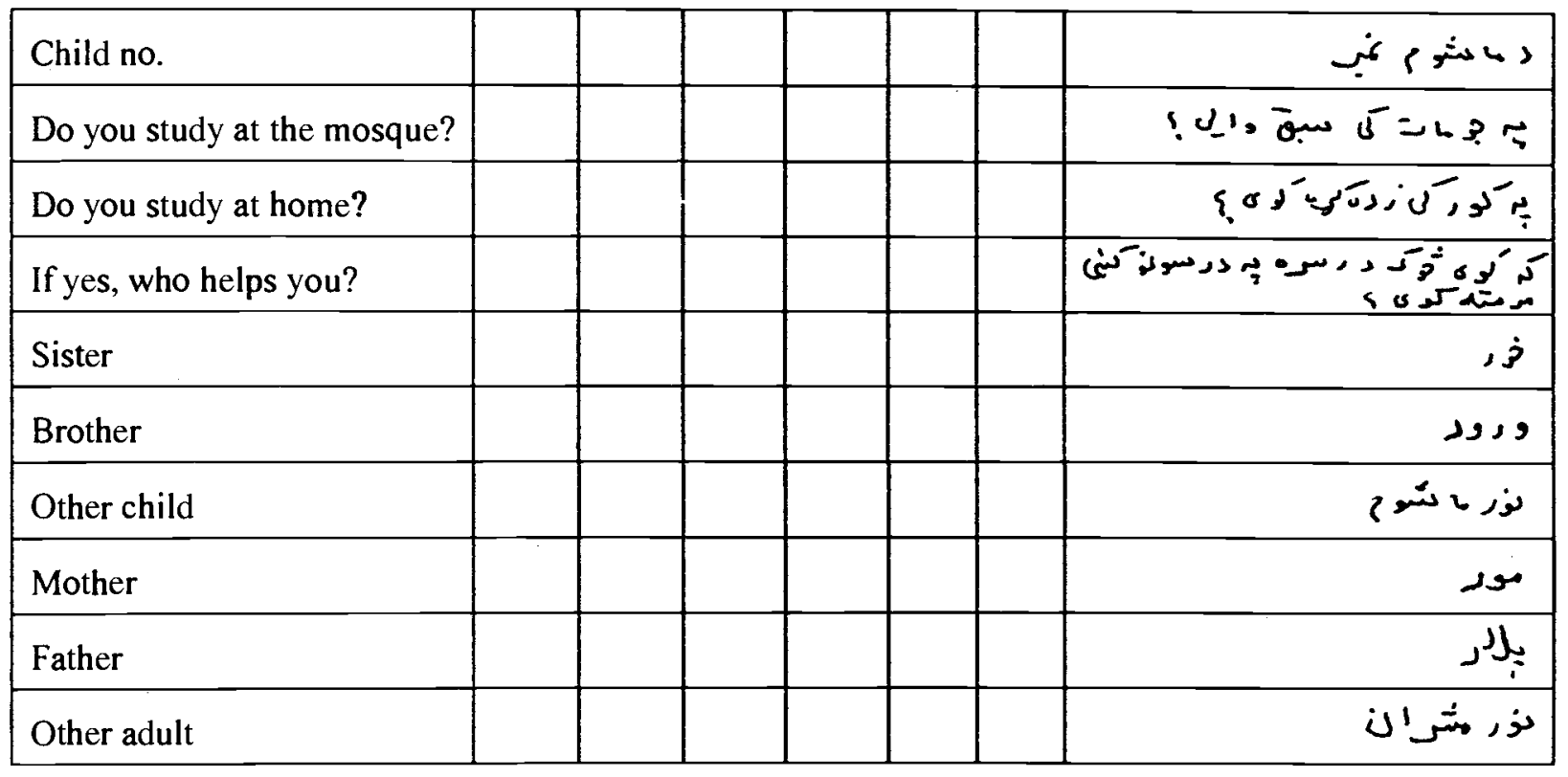

If you stopped attending school, what was the reason?

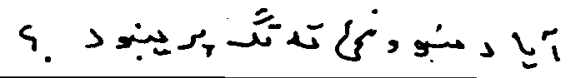

Economic reason

\section{Displacement}

Fighting

Permission

No school

Other

\begin{tabular}{|l|l|l|l|} 
& & & \\
\hline & & & \\
& & & \\
& & & \\
& & & \\
\hline
\end{tabular}

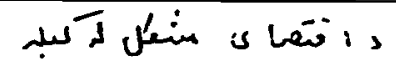

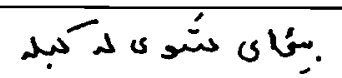

\begin{tabular}{|c|}
\hline \\
\hline اجذه \\
\hline 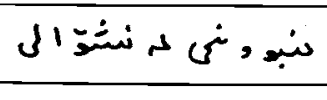 \\
\hline
\end{tabular}

Would you like to go to school? Yes No If yes, why?

$$
\text { ك }
$$


2.2 Work $\perp 6$

What kind of work do you do in the house?

\begin{tabular}{|c|c|c|c|c|c|c|c|}
\hline Child no. & 1 & 2 & 3 & 4 & 5 & 6 & ر هاشتو م نمب \\
\hline $\begin{array}{l}\text { Wash dishes/clothes, cook, } \\
\text { sweep }\end{array}$ & & & & & & & 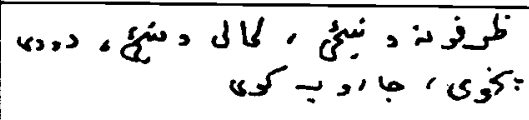 \\
\hline Collect water & & & & & & & I \\
\hline Embroidery & & & & & & & 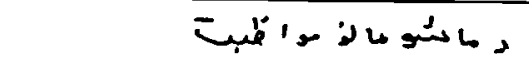 \\
\hline Carpet weaving & & & & & & & تا لَّن \\
\hline Other & & & & & & & لخد \\
\hline
\end{tabular}

What kind of work do you do in the street?

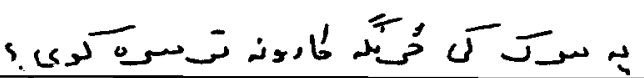

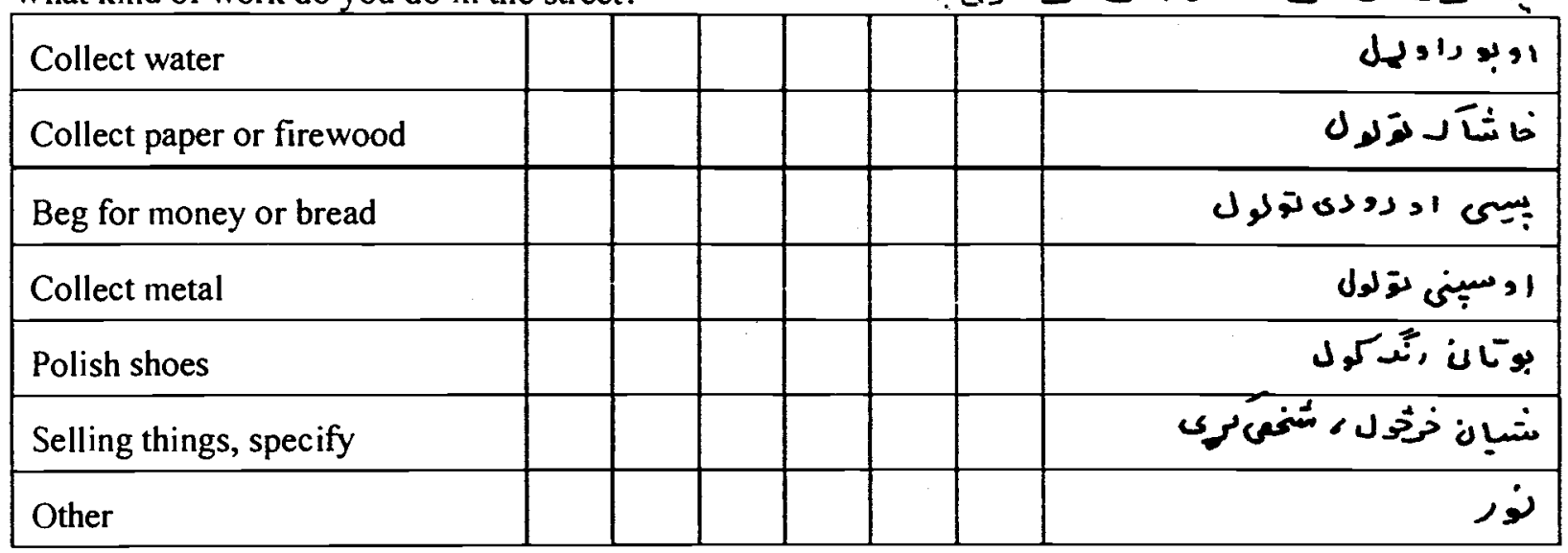

What kind of work do you do on the farm?

(2)

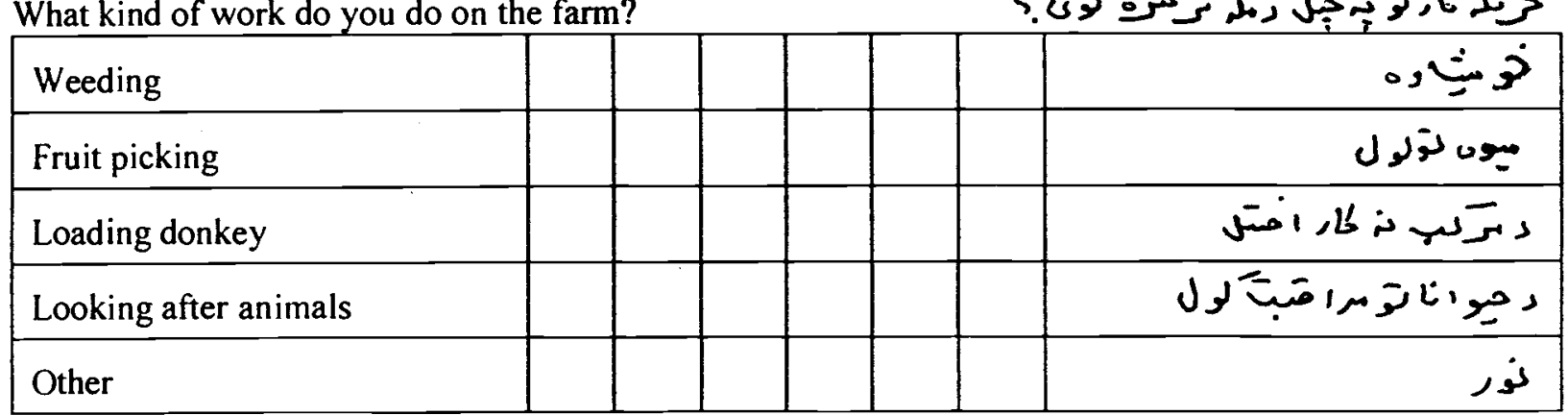

What kind of work do you do in a workshop, shop?

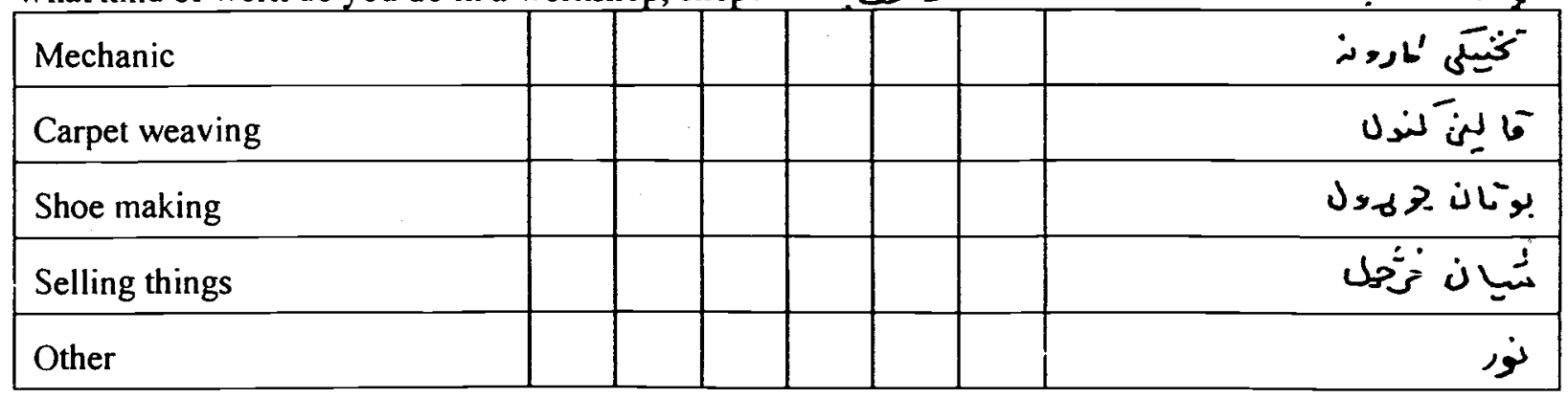




\begin{tabular}{|c|c|c|c|c|c|c|c|}
\hline Child no. & 1 & 2 & 3 & 4 & 5 & 6 & دا شَّوم غنبر \\
\hline $\begin{array}{l}\text { Do you earn money for your } \\
\text { work? }\end{array}$ & & & & & & & 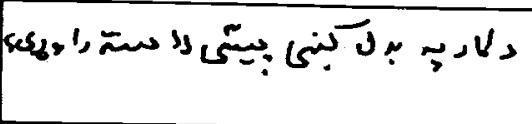 \\
\hline $\begin{array}{l}\text { How much money do you earn } \\
\text { each day? }\end{array}$ & & & & & & & 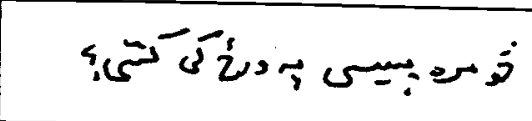 \\
\hline
\end{tabular}

Who do you work with?

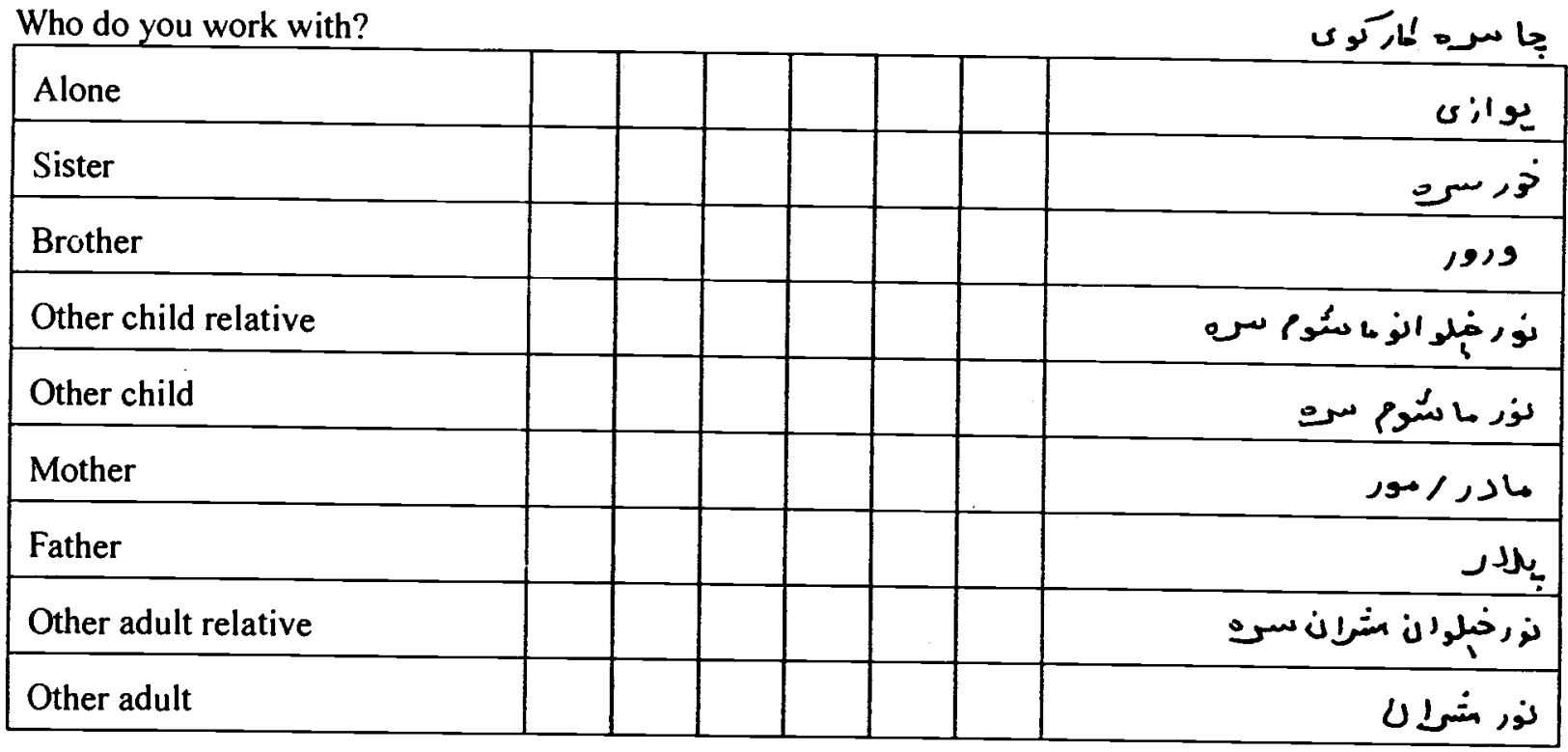




\begin{tabular}{|c|c|c|c|c|c|c|c|}
\hline Child no. & 1 & 2 & 3 & 4 & 5 & 6 & دس شَّح منبــ \\
\hline Do you have any free time? & & & & & & & 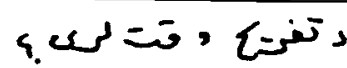 \\
\hline
\end{tabular}

What games do you play?

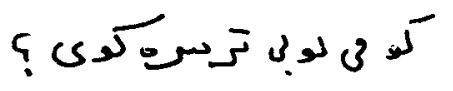

Who do you play with?

(ج)

Sister

Brother

Other relative girl

Other relative boy

Neighbour girl

Neighbour boy

Other

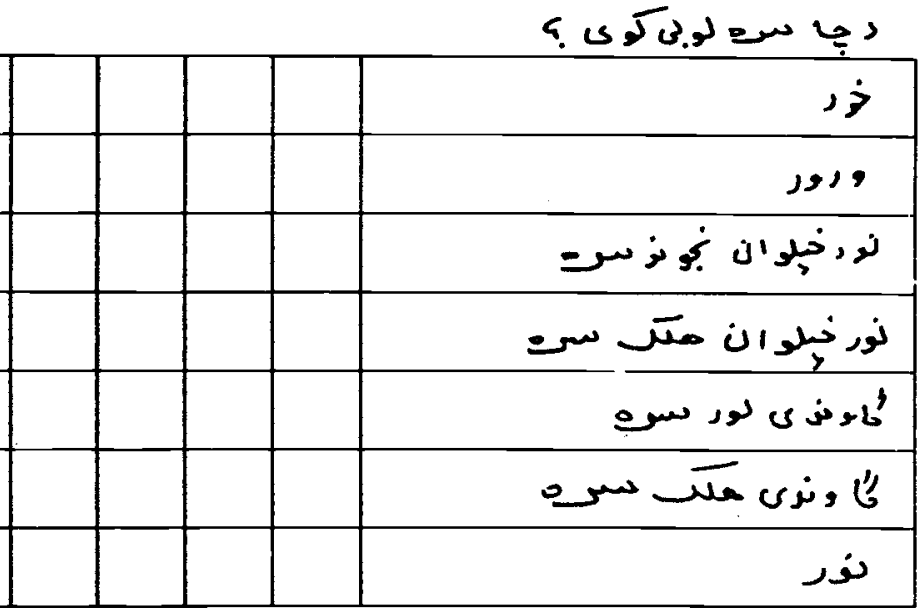

Where do you play?

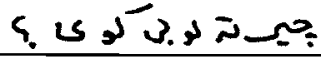

In the house

In the street/lane

In the garden/park

In the playground

In the fields

Other

What games did you play before the war?

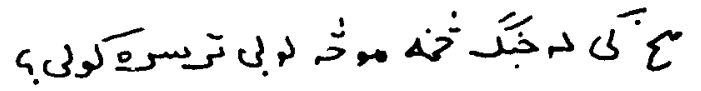

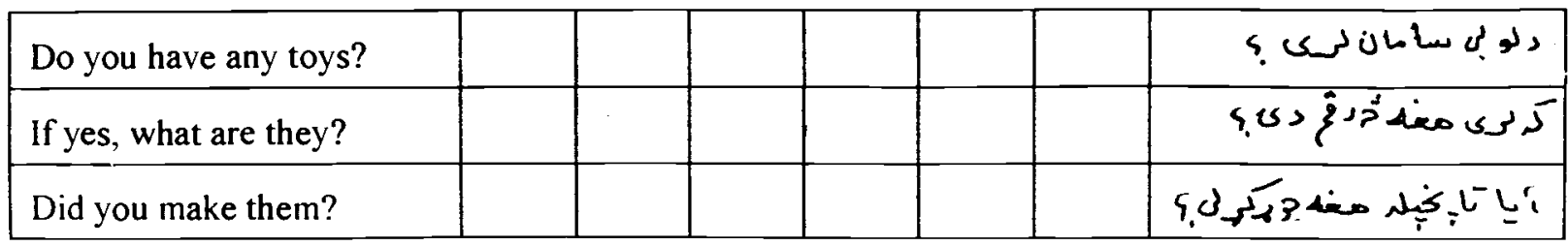


Do adults ever tell you stories?

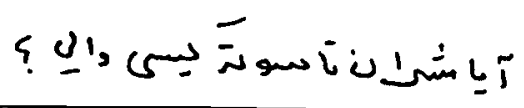

\begin{tabular}{|c|c|c|c|c|c|c|c|}
\hline Child no. & 1 & 2 & 3 & 4 & 5 & 6 & د هاشُو م غنبى \\
\hline Every day & & & & & & & مهر درن \\
\hline Sometimes & & & & & & & مُد 'كم \\
\hline Never & & & & & & & هing \\
\hline
\end{tabular}

If yes, who tells you stories?

\begin{tabular}{|l}
\hline Sister/brother \\
\hline Mother \\
\hline Father \\
\hline Grandmother/Grandfather \\
\hline Other adult, specify who \\
\hline
\end{tabular}

What stories?

$$
\begin{aligned}
& \text { ك. } \\
& \text { ذ }
\end{aligned}
$$

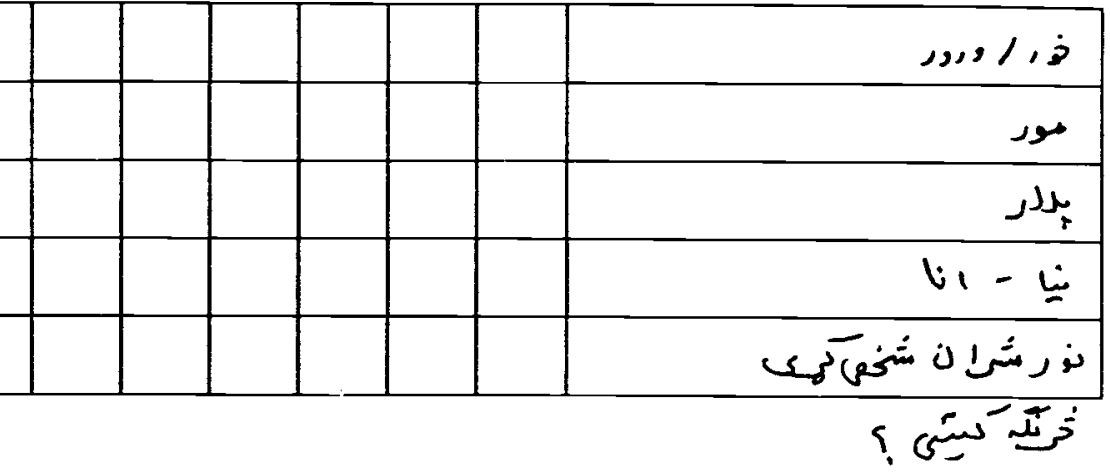

When was the last time adults took you outside the house for a picnic?

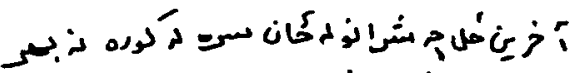

$$
\begin{aligned}
& \text { = }
\end{aligned}
$$

This month

This year

More than 1 year ago

Never

Where do you go during the twoEids?

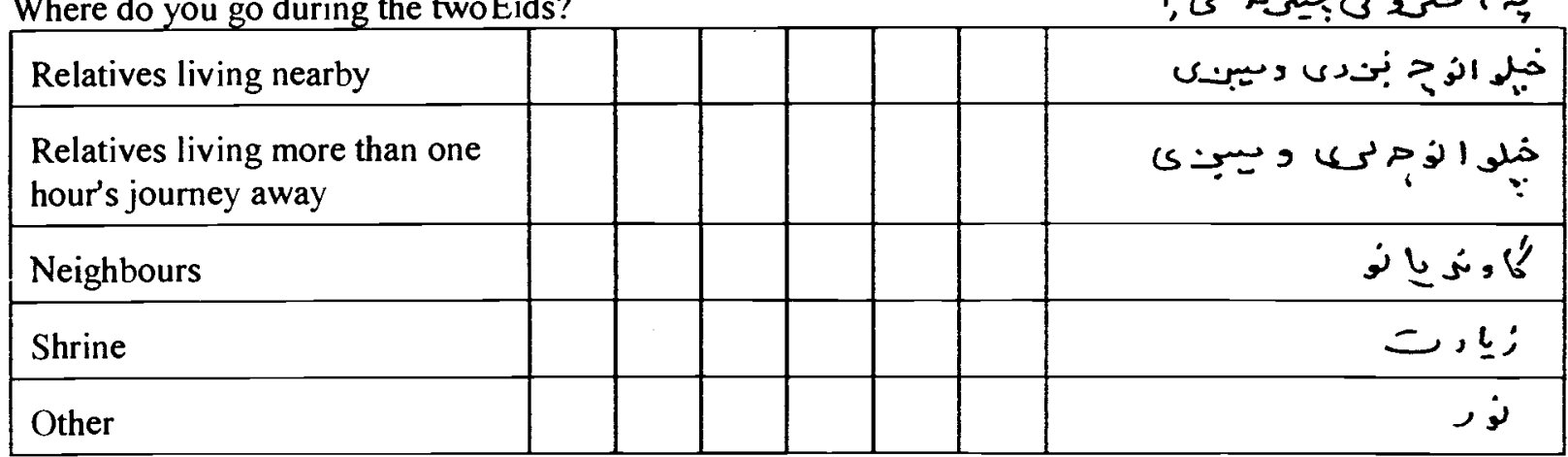

When was the last time you went to a wedding party?

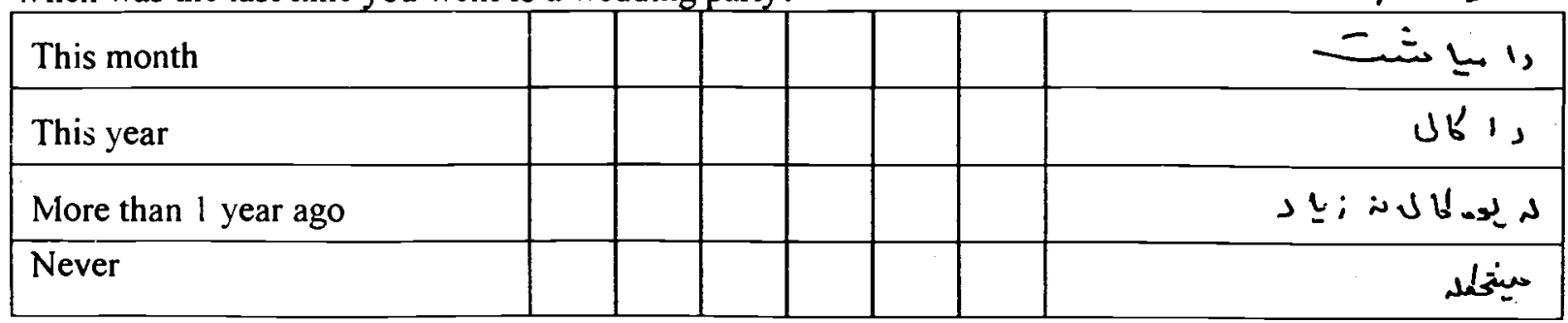


3. Past

Can you tell me an unforgettable story from your life?

(For individual interview only)

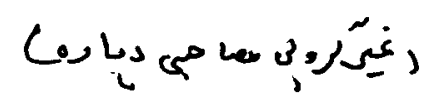

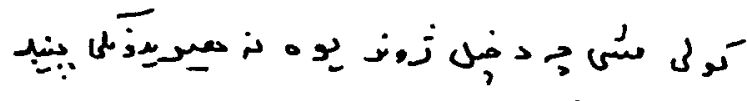

$\{d, g=2$

4. Family and living situation:

ن إيدا

\begin{tabular}{|c|c|c|c|c|c|c|c|c|c|c|}
\hline & $\begin{array}{l}\text { Father } \\
\text { present } \\
\text { and } \\
\text { healthy } \\
\text { (s sils }\end{array}$ & 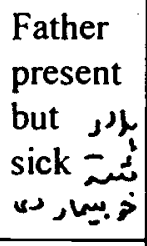 & 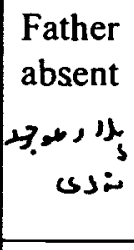 & $\begin{array}{l}\text { Father } \\
\text { dead } \\
\text { sرs }\end{array}$ & $\begin{array}{l}\text { Mother } \\
\text { present } \\
\text { and } \\
\text { healthy }\end{array}$ & 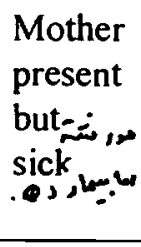 & 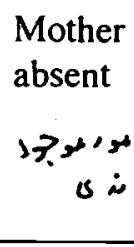 & 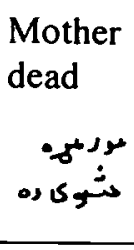 & 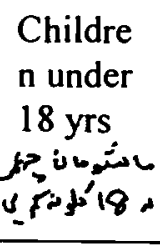 & $\begin{array}{l}\text { Age } \\
\text { range } \\
0 ; 0 \text { s }\end{array}$ \\
\hline 1 & & & & & & & & & & \\
\hline 2 & & & & & & & & & & \\
\hline 3 & & & & & & & & & & \\
\hline 4 & & & & & & & & & & \\
\hline 5 & & & & & & & & & & \\
\hline 6 & & & & & & & & & & \\
\hline
\end{tabular}

\begin{tabular}{|c|c|c|c|c|}
\hline 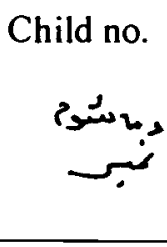 & 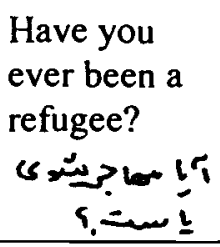 & 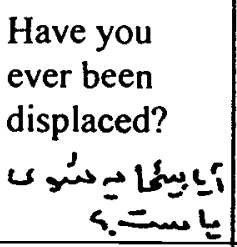 & $\begin{array}{l}\text { Are you still } \\
\text { displaced? }\end{array}$ & $\begin{array}{l}\text { How many years have you been living } \\
\text { in your current house? }\end{array}$ \\
\hline 1 & & & & \\
\hline 2 & & & & \\
\hline 3 & & & & \\
\hline 4 & & & & \\
\hline 5 & & & & \\
\hline 6 & & & & \\
\hline
\end{tabular}


5. War ?ִ

\begin{tabular}{|c|c|c|c|c|}
\hline $\begin{array}{l}\text { Child } \\
\text { no. } \\
\text { sinans }\end{array}$ & 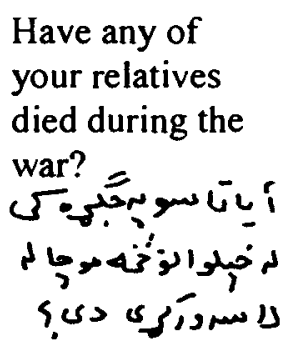 & 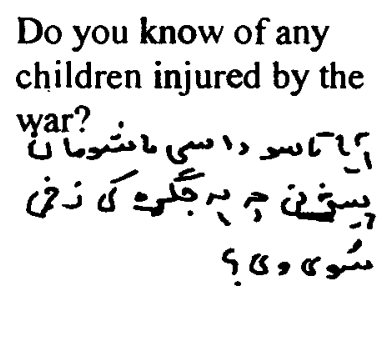 & 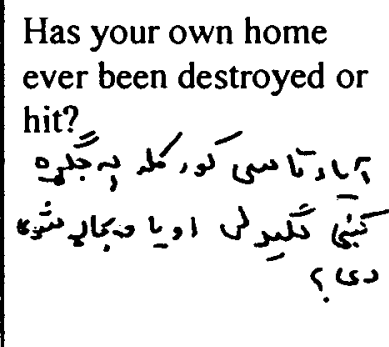 & 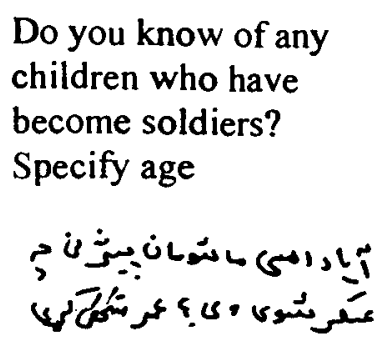 \\
\hline 1 & & & & \\
\hline 2 & & & & \\
\hline 3 & & & & \\
\hline 4 & & & & \\
\hline 5 & & & & \\
\hline 6 & & & & \\
\hline
\end{tabular}

Do aduits talk with you about the war?

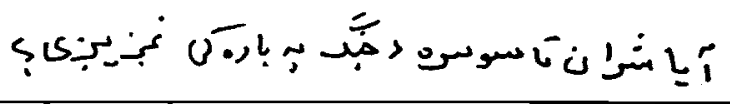

\begin{tabular}{|c|c|c|c|c|c|c|c|}
\hline Child no. & 1 & 2 & 3 & 4 & 5 & 6 & دمانُوا نمب \\
\hline Mother & & & & & & & 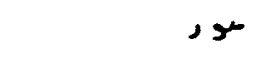 \\
\hline Father & & & & & & & קرار \\
\hline Other female relative & & & & & & & نور :i i is \\
\hline Other male relative & & & & & & & 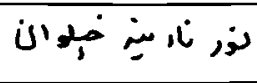 \\
\hline Teacher & & & & & & & نبوَ' \\
\hline Other adult & & & & & & & نور شُراله \\
\hline
\end{tabular}




\begin{tabular}{|c|c|c|c|c|c|c|c|}
\hline Child no. & 1 & 2 & 3 & 4 & 5 & 6 & (s) \\
\hline Do you have a radio? & & & & & & & 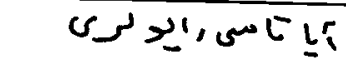 \\
\hline Do you listen to Shariat Radio? & & & & & & & 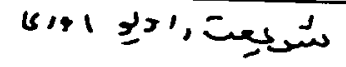 \\
\hline New Life New Home & & & & & & & 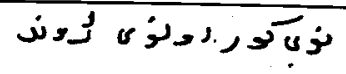 \\
\hline BBC News & & & & & & & 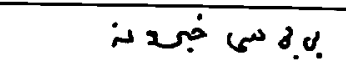 \\
\hline Pakistan radio & & & & & & & $2 \geq 1,4 \sqrt{t}$ \\
\hline Other? & & & & & & & 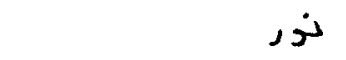 \\
\hline
\end{tabular}

6. Future (anis, Gistis

If we came back in 1 year's time would we find you here?

\begin{tabular}{|c|c|c|c|c|c|c|c|}
\hline Child no. & 1 & 2 & 3 & 4 & 5 & 6 & د מحتو ) نبم \\
\hline Yes & & & & & & & هم \\
\hline No & & & & & & & $\dot{r}$ \\
\hline Don't know & & & & & & & هو \\
\hline
\end{tabular}

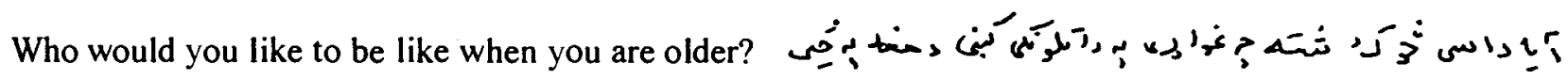
ת, מתו

When you have children, what kind of life do you want to give them?

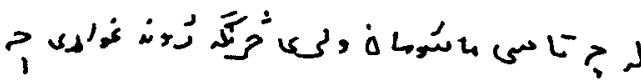

$$
\begin{aligned}
& \text { }
\end{aligned}
$$

We are now going to Kabul, Jalalabad, Kandahar, Herat, Mazar, what message do you have for children there?

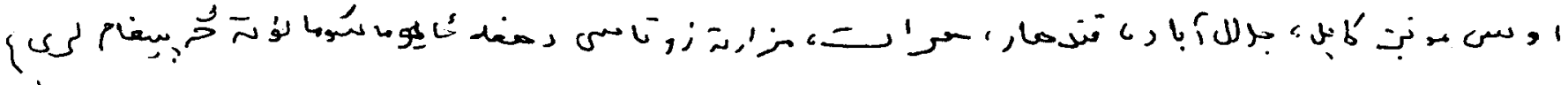




\section{APPENDIX III: ANALYSIS OF RESULTS}

\begin{tabular}{|c|c|c|c|c|c|c|c|}
\hline No. & Description & Kabul & Jalalabad & Mazar & Herat & Kandahar & Total \\
\hline 1 & Urban & 60 & 45 & 13 & 23 & 25 & 166 \\
\hline 2 & Rural & 0 & 43 & 94 & 37 & 66 & 240 \\
\hline 3 & Camp & 0 & 18 & 6 & 45 & 12 & 81 \\
\hline 4 & Female $6-9$ yrs & 17 & 10 & 17 & 5 & 16 & 65 \\
\hline 5 & Female $10-13$ yrs & 14 & 17 & 27 & 21 & 33 & 112 \\
\hline 6 & Female $14-18$ yrs & 1 & 13 & 20 & 23 & 1 & 58 \\
\hline 7 & Male 6-9 yrs & 8 & 11 & 11 & 17 & 8 & 55 \\
\hline 8 & Male $10-13$ yrs & 14 & 32 & 26 & 24 & 20 & 116 \\
\hline 9 & Male $14-18$ yrs & 6 & 23 & 18 & 15 & 25 & 87 \\
\hline 10 & Mobility disability & 4 & 8 & 2 & 11 & 3 & 28 \\
\hline 11 & Sensory disability & 0 & 7 & 0 & 2 & 1 & 10 \\
\hline 12 & Mental disability & 0 & 2 & 0 & 0 & 3 & 5 \\
\hline 13 & Cause of disability: War & 4 & 5 & 2 & 3 & 3 & 17 \\
\hline 14 & Cause of disability: Disease & 0 & 4 & 0 & 8 & 0 & 12 \\
\hline 15 & Cause of disability: Birth Complication & 1 & 6 & 0 & 2 & 0 & 9 \\
\hline 16 & Cause of disability: Accident & $\mathrm{NA}$ & NA & 0 & 0 & 5 & 5 \\
\hline 17 & Now in school & 36 & 43 & 85 & 64 & 34 & 262 \\
\hline 18 & Has books at home & 11 & 48 & 41 & 74 & 30 & 204 \\
\hline 19 & Studies at mosque & 11 & 36 & 56 & 51 & 54 & 208 \\
\hline 20 & Stopped school for economic reasons & 10 & 9 & 4 & 5 & 11 & 39 \\
\hline 21 & Stopped school because of displacement & 6 & 2 & 2 & 0 & 3 & 13 \\
\hline 22 & Stopped school because of fighting & 2 & 1 & 3 & 0 & 1 & 7 \\
\hline 23 & Stopped school because no permission given & 22 & 32 & 18 & 10 & 2 & 84 \\
\hline 24 & Stopped school because no teacher & 0 & 12 & 3 & 3 & 4 & 22 \\
\hline 25 & Independent unpaid street work & 16 & 4 & 7 & 11 & 22 & 60 \\
\hline 26 & Independent paid street work & 5 & 11 & 3 & 6 & 0 & 25 \\
\hline 27 & Supervised unpaid work & 0 & 23 & 26 & 7 & 5 & 61 \\
\hline 28 & Supervised paid work & 2 & 13 & 13 & 22 & 22 & 72 \\
\hline 29 & Never told stories & 0 & 28 & 24 & 7 & 47 & 106 \\
\hline 30 & Never been on a picnic & 15 & 37 & 26 & 17 & 28 & 123 \\
\hline 31 & Last wedding party more than 1 year ago & 33 & 22 & 28 & 26 & 16 & 125 \\
\hline 32 & Father sick & 0 & 31 & 5 & 15 & 11 & 62 \\
\hline 33 & Father dead & 24 & 19 & 17 & 17 & 17 & 94 \\
\hline 34 & Mother sick & 4 & 18 & 2 & 11 & 13 & 48 \\
\hline 35 & Mother dead & 5 & 1 & 10 & 8 & 8 & 32 \\
\hline 36 & Still displaced & 6 & 44 & 36 & 54 & 24 & 164 \\
\hline 37 & Relatives died because of war & 41 & 75 & 54 & 55 & 65 & 290 \\
\hline 38 & Knows other children injured because of war & 46 & 46 & 24 & 31 & 26 & 173 \\
\hline 39 & Own home destroyed because of war & 54 & 75 & 24 & 61 & 52 & 266 \\
\hline 40 & Knows of child soldiers & 19 & 17 & 18 & 10 & 10 & 74 \\
\hline 41. & Adults do not discuss war with child & 23 & 32 & 42 & 40 & 40 & 177 \\
\hline
\end{tabular}

* Any discrepancies in totals of responses indicate that not all children responded. 


\section{APPENDIX IV: CASE STUDIES}

Case study 1 Internally displaced boy working on the streets in Jalalabad

One of the project researchers met Fawad in the late afternoon on Friday 18 July 1997 in the bazaar in Jalalabad city where he was selling water. The researcher invited Fawad to talk with him, and Fawad agreed but was worried that he would suffer loss of earnings. He was reassured that his loss of earnings would be made up. The researcher talked with him without interruptions in the UNICEF vehicle and gave him 5000 Afs.

Fawad is a twelve year old boy who came to Jalalabad in 1994 from the Bagrami district outside Kabul. He is the oldest of eleven children. He told the story of his flight from his family's home in Bagrami as follows:

"It was a winter night when fighting reached our village. I remember we were having dinner, when one of our neighbours was injured. All the people, women, children and men, wanted to leave the village. By nine o'clock at night we managed to escape. When we arrived in the village of Kamari one of our relatives was injured. Women and small children were crying, because of the war and bullets which were around them. We passed several troubled nights in Kamari, waiting for a more peaceful and secure time to move on to another place."

"The war slowed down, and we escaped to Jalalabad. Here we live in Chaknauri, and pay 30,000Afs per month for a house with no electricity. The owner of the house keeps saying, "today I will provide you with electricity", but it has never happened. My father is very weak and works in the bazaar as a porter. He earns between 15,000 and 20,000 Afs each day. I sell water and make about 10,000 Afs per day, and of this I spend 5,000 Afs on buying ice to cool the water."

Fawad has never been to school, but he does study at the mosque. There are no books in his home. He would like to go to school in the future. "School is good", he told the research assistant, "now you are reading and writing but I can't". However, he does not know how long he will stay in Jalalabad and cannot make any plans. At home he is busy looking after younger brothers and sisters, and he also goes out shopping and collecting water for the household. When he sells water on the street he works alone, and gives his earnings to his family.

Fawad has some free time, and he plays Kung Fu with neighbouring boys in the lane outside his home. He has no toys. Fawad has never been told stories or been taken by any adult on a picnic. Cut off from their relatives who are all near Kabul, Fawad and his family do not go visiting at the two Eid festivals; instead he walks around the bazaar.

Both Fawad's parents are alive, and it is with his father he talks if he has a problem. However no adult talks with Fawad about the war, and he does not know why people are fighting. His family does not have a radio.

As for the future, Fawad thinks that he will still be selling water in the bazaar next year. When he is older he would like to have studied and be able to become a teacher. When he himself is a parent, he wants his own children to go to school and to the mosque, and be able to look after him and provide him with food when he is old.

Fawad's message for other children in Afghanistan is "get an education and take of care of your parents". 
Shamin is eighteen and lives in her older brother's home in the Said Abad district of Mazar-iSharif. She has another brother and three sisters who are living in her father's home in Hazarajat where she was born. Her older brother works in a health clinic and married a year ago. He and his wife have no children.

In 1984 Shamin's older brother went to Pakistan because the leader of the Harakat party wanted him to become a fighter, but her brother did not want to fight. In Pakistan the Harakat party again contacted him to join the fight against the Russians but instead he continued his work in a bakery and went to school. In 1989 her mother left her husband and other children and went to visit her son in Pakistan. After two years they were returning to Hazarajat together when they were surrounded by thieves. The shock of seeing the thieves attack her son caused her mother's heart to fail. Eventually the son was freed and he brought the body of his mother back to Hazarajat for burial.

The next time her brother went to Pakistan, Shamin accompanied him. By that time she was twelve years old, and once in Karachi she enrolled in school. For two years from 1991-93 she attended school and moved quickly through the grades. When in 1993 she returned to Hazarajat she had to stop attending school. It was not until she moved to Mazar-i-Sharif that Shamin was able to continue her schooling when she joined the third class of a school in Said Abad. Shamin is also attending a tailoring course and makes her own clothes. She is determined not to get married until she has finished school, and then she would like to be a doctor.

Shamin has talked about her plans with her older brother. He ways that whether she continues school and when she gets married will depend on the situation in Afghanistan. Notebooks, other school equipment and clothes are expensive. For the time being they can make ends meet and will continue trying.

In her free time Shamin watches television. She can choose between programmes broadcast from Iran, Uzbekistan and the local Balkh television station.

Shamin's message for other children in Afghanistan is "work hard, study and rebuild Afghanistan". 
Rädda Barnen

Room 228, 2nd Floor

Gul Haji Plaza

Jamrud Road

Peshawar N.W.F.P.

Pakistan

Ph: 9291840987

Fax: 9291840349

Save the Children (UK)

194-A, College Road

F-7/3

Islamabad

Pakistan

Ph: $9251279214 / 5$

Fax: 9251279216

E-mail: scfuk@infolink.net.pk
Save the Children Federation, Inc.

P.O. Box 1952

Islamabad

Pakistan

Ph: 9251279212

Fax: 9251279210

United Nations Children's Fund

Afghanistan Country Office

17-B, Abdara Road

University Town

P.O. Box 1078

Peshawar

Pakistan

Ph: 929143669

Fax: 9291840437 